T.C.

MARMARA UNIVERSITY

INSTITUTE OF SOCIAL SCIENCES

BUSINESS ADMINISTRATION

DEPARTMENT OF ACCOUNTING AND FINANCE

\title{
ENERGY DERIVATIVE MARKETS
}

Master Thesis

POLAD AZIZOV

Istanbul, 2010 
T.C.

MARMARA UNIVERSITY

INSTITUTE OF SOCIAL SCIENCES

BUSINESS ADMINISTRATION

DEPARTMENT OF ACCOUNTING AND FINANCE

\section{ENERGY DERIVATIVE MARKETS}

Master Thesis

POLAD AZIZOV

Adviser: Associate Professor CEYDA RUKIYE ÖZTÜRK

Istanbul, 2010 


\section{Marmara Üniversitesi \\ Sosyal Bilimler Enstitüsü Müdürlüğü}

\section{Tez Onay Belgesi}

IŞLETME Anabilim Dalı MUHASEBE FINANSMAN(ING) Bilim Dalı Yüksek Lisans öğrencisi POLAD AZIZOV nın ENERGY DERIVATIVE MARKETS adlı tez çalışması ,Enstitümüz Yönetim Kurulunun 24.03.2010 tarih ve 2010-5/30 sayılı kararıyla oluşturulan jüri tarafından oybirliği//le Yüksek Lisans Tezi olarak kabul edilmiştir.

Tez Savunma Tarihi : 28.1.04/.2\%10

1) Tez Danışmanı : YRD. DOÇ.DR. CEYDA RUKIYE ÖZTÜRK

2) Jüri Üyesi : DOÇ. DR. JALE SÖZER ORAN

3) Jüri Üyesi $\quad$ : YRD. DOÇ.DR. IDIL ÖZLEM KOÇ

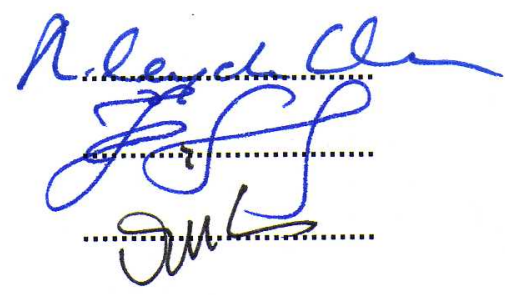




\begin{abstract}
With the recent developments in price determination of energy commodity products all over the world, which has dramatically changed by the application of deregulations and liberalizations since 1960's have faced energy markets with price risk and other energy market related risks. Energy-intensive industrials faced uncertainties because of extreme price fluctuations and instability of the energy supply. So, the major participants of these markets had to hedge wholly or partially against these risks. As a result, beginning from the 1980's the derivative products which have been successfully used in financial markets for hedging price risk, currency and interest risks, have began to be used in energy markets. The widespread of energy related derivative exchanges in the world generally depends on development level of countries and their markets. The contract volumes in energy markets have been increasing both in exchange and OTC markets over the past decades. This study offers a focused investigation of recent condition of existing energy markets both in "over the world" and Turkey context. The interdependence of futures oil prices with spot oil prices is evaluated within the research.
\end{abstract}

KEY WORDS: $\quad$ World Energy Markets, Energy Derivatives, Energy Exchanges 


\section{ÖZET}

Dünyada enerji emtia ürünlerinin fiyat belirlenmesi deregülasyon ve liberalizasyonların uygulanmasıyla önemli ölçüde değişmiş, enerji piyasalarını fiyat riski ve diğer enerji piyasasıyla ilgili risklerle karşı karşıya bırakmıştır. Bu piyasaların en önemli katılımcıları aşırı fiyat dalgalanmaları, enerji arzında istikrarsızlık nedeniyle belirsizliklerle karşılaşmış ve tamamen yada kısmen bu risklere karşı hedge yapmak zorunda kalmışlardı. Sonuç olarak, 1980 yllından itibaren finansal piyasalarda fiyat riski, döviz ve faiz risklerinden korunmak için başarılı bir şekilde kullanılmakta olan türev ürünleri enerji piyasalarında da kullanılmaya başlandı. Dünyada enerji türev borsalarının yaygınlığı genelde ülke ve piyasaların gelişmişlik düzeyi ile bağlıdır. Son yıllar itibarile enerji piyasalarında türev sözleşmelerinin işlem hacmi hem borsalarda hemde tezgah üstü piyasalarda yükselme trendi göstermektedir. Bu çalışma Dünya ve Türkiye bağlamında mevcut enerji piyasaların son durumuna odaklanmış bir araştırma sunmaktadır. Spot petrol piyasası fiyatları ile vadeli petrol piyasa fiyatları arasındaki karşılıklı bă̆lılık bu araştırmada değerlendirilmiştir.

Anahtar Kelimeler: $\quad$ Dünya Enerji Piyasaları, Enerji Türevleri, Enerji Borsaları 


\section{FOREWORD}

My native country Azerbaijan is blessed with a plenty of energy resources. But the financial risk management in this country for today is too underdeveloped in all sectors including the energy markets. However with the recent development rates of Azerbaijan, which is one of the highest in the world, I believe that this phenomenon will turn into a positive reverse in the nearest future.

This thesis couldn't have been prepared without existence of some precious people surrounding me. I am grateful to my family for their endless patience and support, to all my friends for just their existence and my supervisor Professor Ceyda Rukiye Öztürk for her strong contribution in my thesis research. 


\section{CONTENTS}

TABLES

GRAPHS

FIGURES

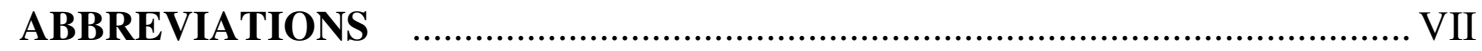

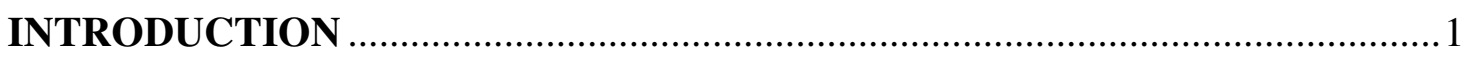

\section{WORLD ENERGY MARKETS: ENERGY MARKET RISKS}

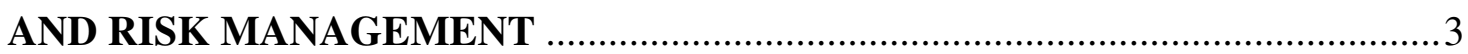

1.1. PRIMARY ENERGY MARKETS …..................................................... 3

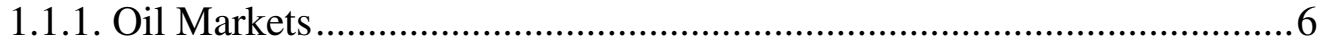

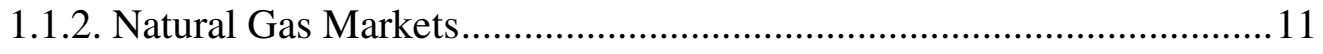

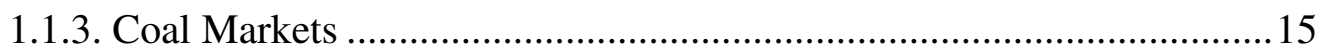

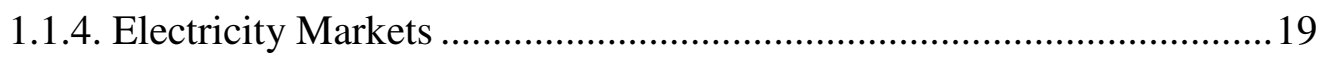

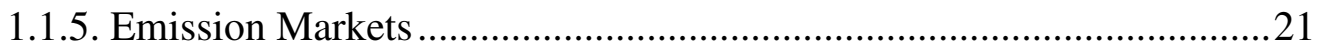

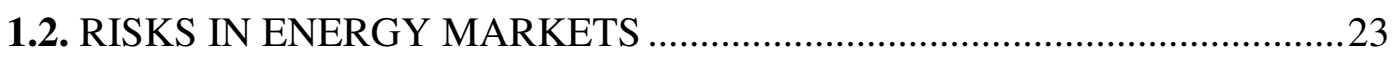

1.2.1. The Aim of Risk Management ..........................................................24

1.2.2. Types of Risks in Energy Markets ....................................................24

1.2.3. Energy Markets vs Money Markets ...................................................28

1.2.4. Risk Management in Energy Markets ................................................29

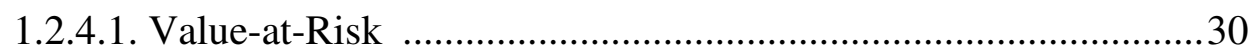

1.2.4.1.1. The Variance-Covariance Model ....................................31

1.2.4.1.2. Monte Carlo Simulations ..................................................32

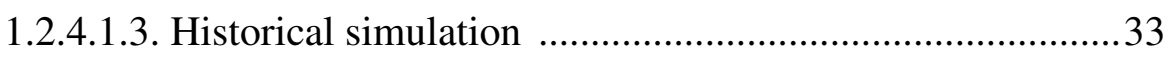

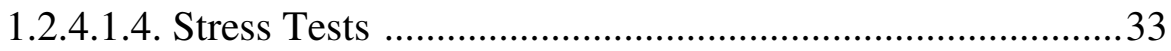

1.2.5. Common Risk Management Tools ........................................................34

\section{DERIVATIVE MARKETS AND ENERGY DERIVATIVES}

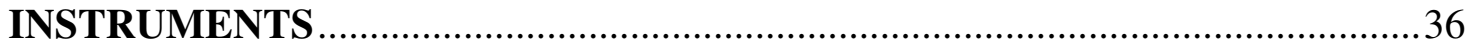

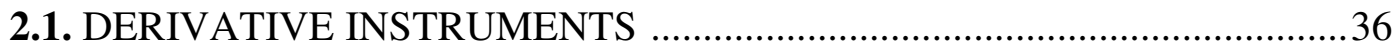

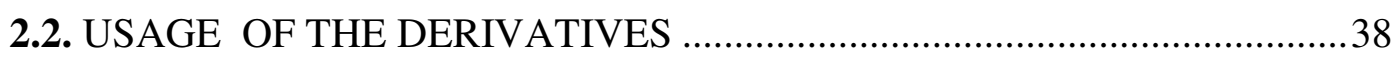

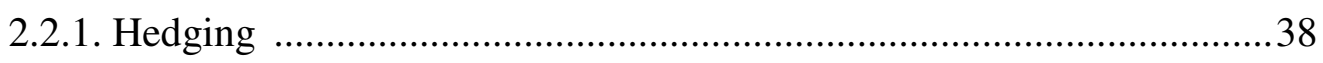

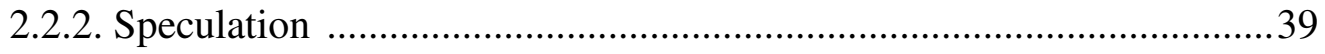




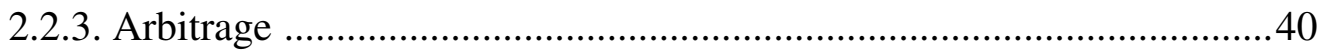

2.3. TYPES OF DERIVATIVES MARKETS ....................................................41

2.3.1. Organized Energy Exchange Markets ............................................... 41

2.3.2. Over-the-Counter Energy Markets ..................................................... 41

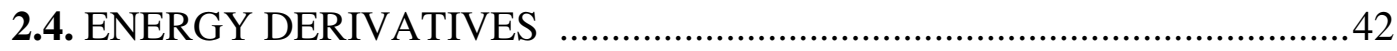

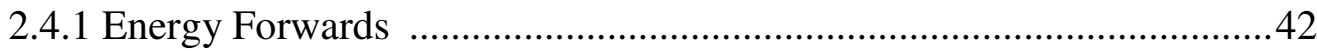

2.4.1.1. The Value of Energy Forward Contract ...................................44

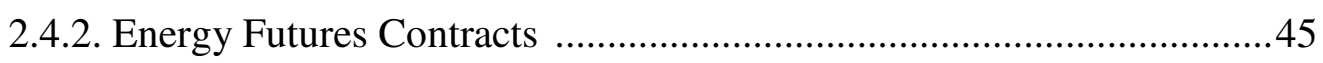

2.4.2.1. Counterparties in Energy Futures Contracts .............................46

2.4.2.2. Margin Requirements and Clearinghouses in Energy Futures Contracts .....................................................4 47

2.4.3. Energy Option Contracts .................................................................50

2.4.3.1. Option Premium ................................................................50

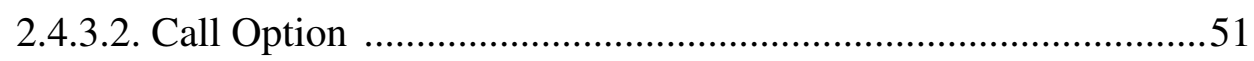

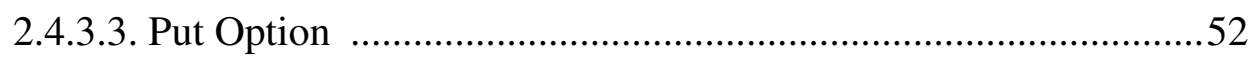

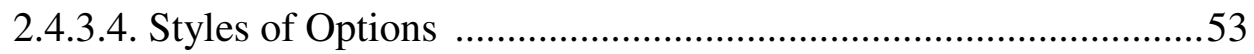

2.4.3.5. Energy Option Strategies .......................................................54

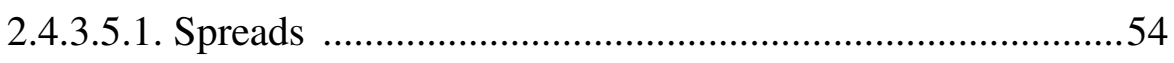

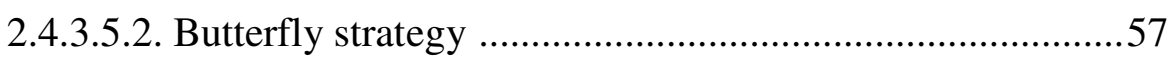

2.4.3.5.3. Calendar Spread ..........................................................57

2.4.3.5.4. Diagonal Spreads ......................................................58

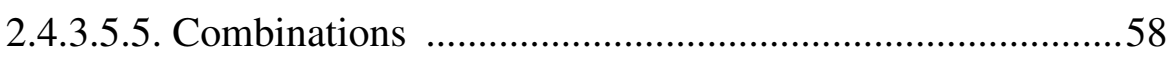

2.4.3.6. Option Pricing ............................................................................60

2.4.3.6.1. Black - Scholes Model ..................................................60

2.4.3.6.2. Tree Models .....................................................................61

2.4.3.6.3. Barone - Adesi Whaley Model .....................................62

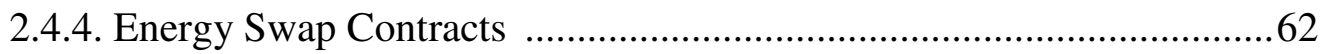

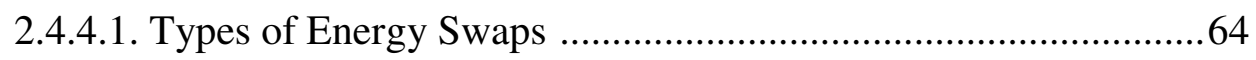

2.4.4.2. Pricing Energy Swaps ...........................................................67

2.5. Weather Derivatives and Energy Markets ...................................................67

2.5.1. Weather Derivatives Contracts ............................................................68

2.5.2. Types of Weather Derivatives .........................................................69

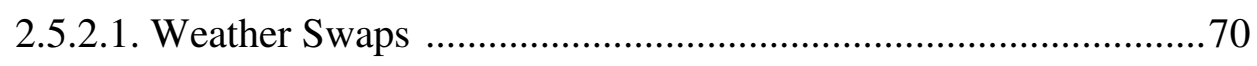

2.5.2.2. Weather Options ..................................................................... 70

2.5.2.3. Weather Derivatives vs Insurance Contracts .............................71 


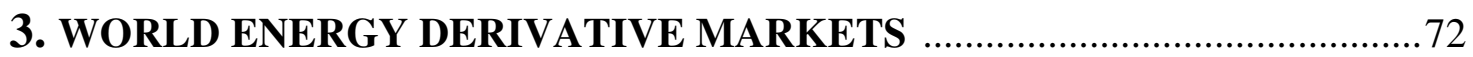

3.1. Evolution of Energy Derivative Markets ......................................................72

3.2. Top Energy Markets of the World Regions …………………………….........77

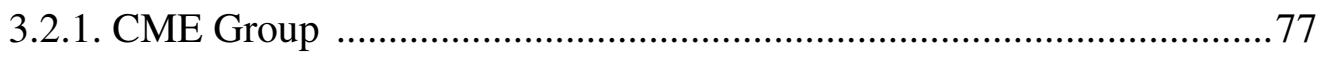

3.2.2. New-York Mercantile Exchange ………………………………........

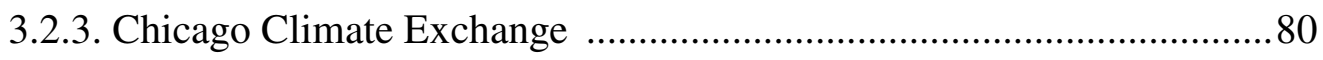

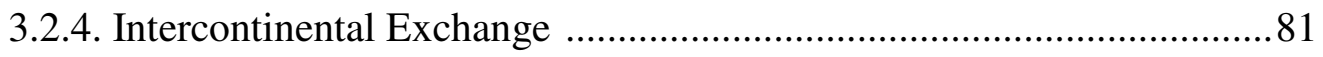

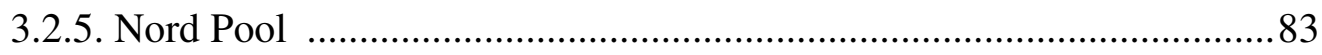

3.2.6. European Energy Exchange .............................................................. 85

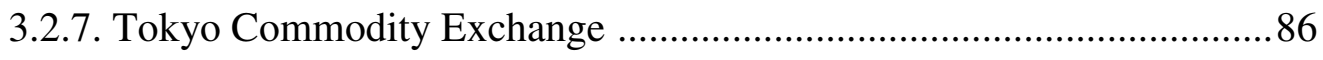

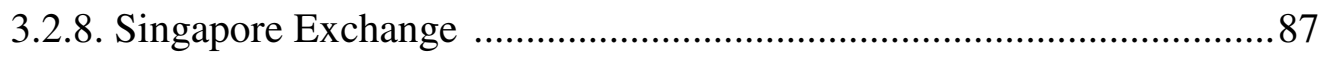

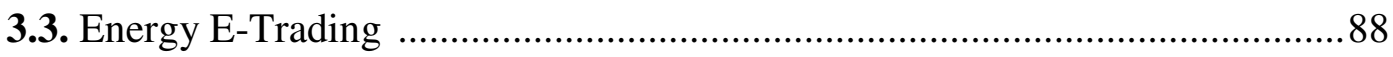

3.3.1. North American Electronic Energy Platforms ……………………......8

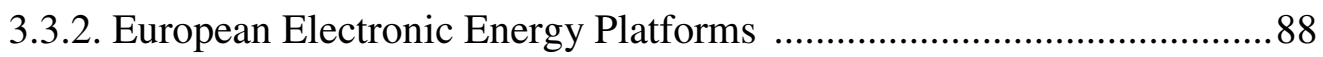

3.3.3. Asian Electronic Energy Platforms …………………………......... 90

3.4. Energy Hedge Funds .......................................................................... 91

\section{ENERGY MARKETS AND THE APPLICABILITY OF ENERGY}

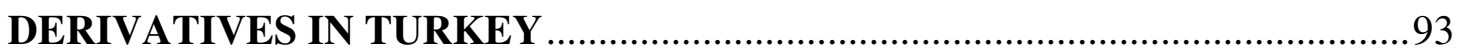

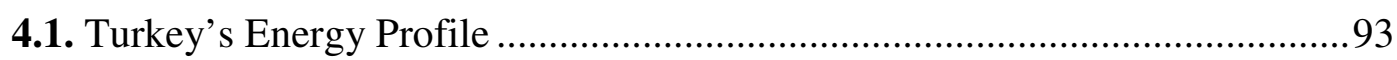

4.1.1. Primary Energy Markets .....................................................................99

4.1.2. Liberalization and Organization of Energy Markets .............................98

4.1.3. Energy Policy and Main Energy Projects of Turkey...........................101

4.2. Energy Derivative Markets and Turkey ……………………………............... 104

4.2.1. Evolution of Derivative Markets and TurkDEX .................................104

4.2.2. Applicability of Energy Derivatives in Turkey …………………........107

4.3. Comparison of Spot and Future Petroleum Prices ........................................111

4.3.1. Data and Methodology .....................................................................111

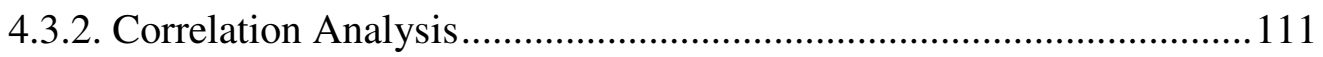

4.3.3. Regression Analysis ........................................................................112

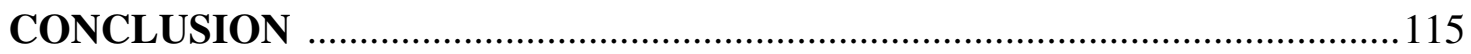

References 


\section{TABLES}

Table 1.1. Energy and money markets differences......................... 28

Table 2.1. Hedging natural gas price risk with futures contract $\ldots \ldots \ldots \ldots \ldots \ldots \ldots 39$

Table 2.2. Example of a Fixed-price Forward Contract for a Power Delivery ......43

Table 2.3. Energy Futures Contracts Trading More Than 100,000

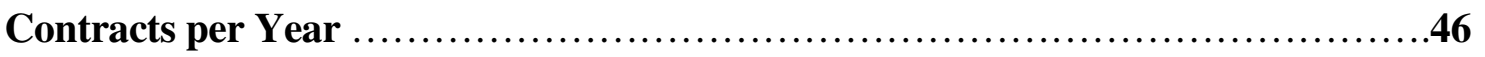

Table 2.4. Example of an Oil Futures Contract ...............................49

Table 3.1. Global listed derivatives volume by category .......................74

Table 3.2. Top 20 energy futures and options worldwide .....................75

Table 3.3. WTI light sweet crude oil futures contract specifications ...............79

Table 4.1. Investment Needs of Turkish Energy Sector ......................101

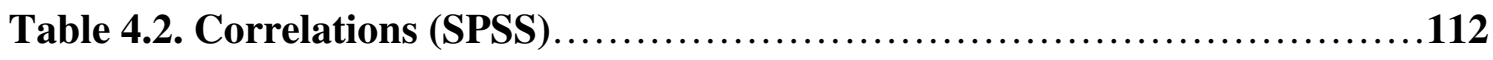

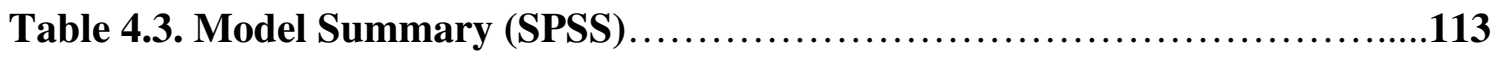

Table 4.4. ANOVA (SPSS) ..............................................

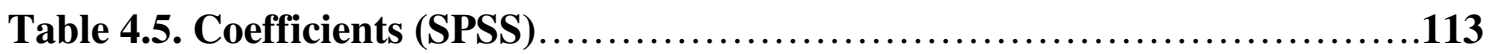




\section{GRAPHS}

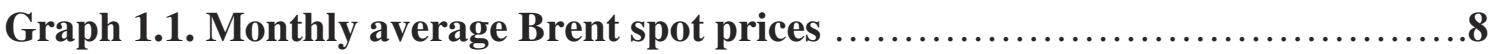

Graph 1.2. Monthly average NYMEX Henry Hub Gas Futures prices ............13

Graph 1.3. Historical spot prices of Central Appalachian and Northwest Europe coal benchmarks (1990-2008) ...............................................

Graph 1.4. Hourly Price of Electricity in USD, PJM, April 1-8, $2008 \ldots \ldots \ldots \ldots \ldots 21$

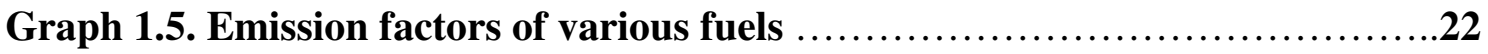

Graph 3.1. Monthly futures and options trading volume in

CCFE (06.2008-06.2009) ..................................................

Graph 3.2. Yearly trading volume of some energy futures products

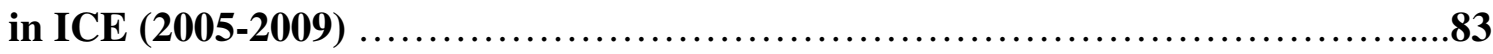

Graph 3.3. Yearly trading volume of energy products in TOCOM (1999-2008)...86

Graph 4.1. Turkey's Total Primary Energy Supply, 1973-2020 „...............94

Graph 4.2. Energy consumption in different sector, 1997 and 2007 (Mtoe) ........95

Graph 4.3. Energy Production by Source in Turkey, 1973-2020 .................96

Graph 4.4. Transaction volumes of TurkDEX,

2005-2008(number of contracts) ..................................... 105

Graph 4.5. Transaction volumes of TurkDEX, 2005-2008 (TL) ...............106

Graph 4.6. Scatter Plot of Variables.......................................111

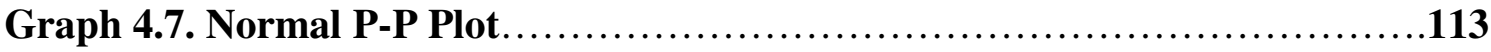

Graph 4.8. Scatter Plot of Regression Standardised Residual

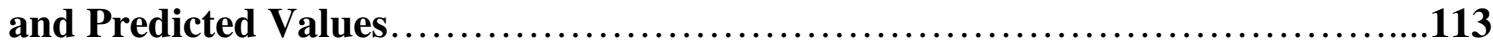




\section{FIGURES}

Figure1.1. World primary energy source consumption $\ldots \ldots \ldots \ldots \ldots \ldots \ldots \ldots \ldots$

Figure 2.1. Profit from buying a European call option on one barrel of oil ........51

Figure 2.2. Profit from buying a European put option on

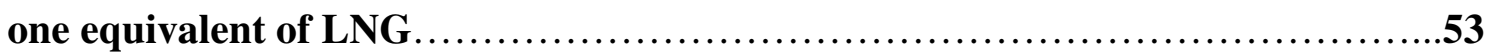

Figure 2.3. Bull spread created using call options ..........................55

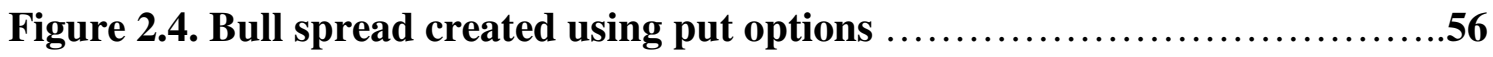

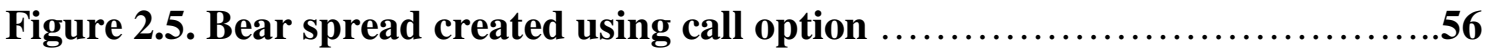

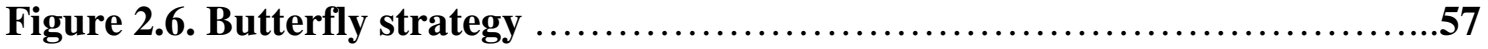

Figure 2.7. A straddle ..........................................................

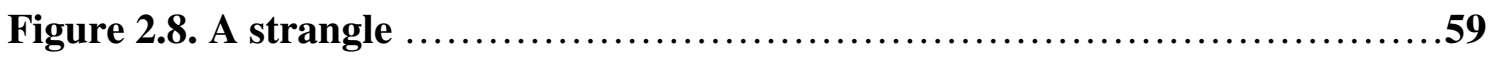

Figure 2.9. Crude Oil Swap Contract Between an Oil Producer and a Refiner.....63

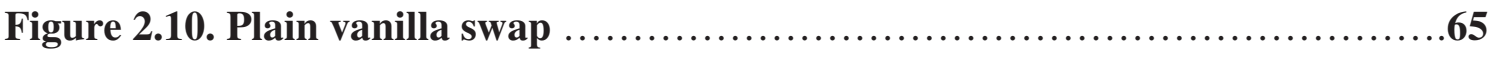

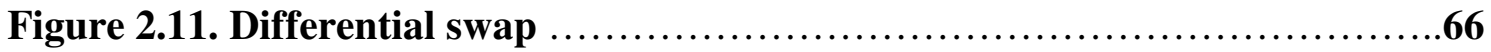

Figure 3.1. Locations of exchanges trading electricity $\ldots \ldots \ldots \ldots \ldots \ldots \ldots \ldots \ldots \ldots 7$ 


\section{ABBREVIATIONS}

$\begin{array}{ll}\text { Bcm: } & \text { Billion cubic metres } \\ \text { BFO: } & \text { Brent, Forties and Oseberg streams } \\ \text { BOTAŞ: } & \text { Turkish Petroleum Pipeline Corporation } \\ \text { CCX: } & \text { Chicago Climate Exchange } \\ \text { CDD: } & \text { cooling degree-days } \\ \text { CME: } & \text { Chicago Mercantile Exchange } \\ \text { EEX: } & \text { European Energy Exchange } \\ \text { EFP: } & \text { Exchange Futures for Physical } \\ \text { EPDK: } & \text { Energy Market Regulatory Authority } \\ \text { EÜAŞ: } & \text { Electricity Generation Company } \\ \text { FOB: } & \text { Free on Board } \\ \text { HDD: } & \text { heating degree-days } \\ \text { ICE: } & \text { InterContinental Exchange } \\ \text { IEA: } & \text { International Energy Agency } \\ \text { IPE: } & \text { International Petroleum Exchange } \\ \text { ISE: } & \text { Istanbul Stock Exchange } \\ \text { LNG: } & \text { Liquefied Natural Gas } \\ \text { MMBTU: } & \text { Million British Thermal Unit } \\ \text { Mtoe: } & \text { Million Tons of Oil Equivalent } \\ \text { NYMEX: } & \text { New-York Mercantile Exchange } \\ \text { OPEC: } & \text { Organization of Petroleum Exporting Countries } \\ \text { OTC: } & \text { Over-the-Counter markets } \\ \text { P\&L: } & \text { Profit \& Loss Statement } \\ \text { PJM: } & \text { Pennsylvania-Jersey-Maryland electricity transmission system } \\ \text { SGX: } & \text { Singapore Exchange } \\ \text { SHFE: } & \text { Shanghai Futures Exchange } \\ \text { TOCOM: } & \text { Tokyo Commodity Exchange } \\ \text { TPES: } & \text { Total Primary Energy Supply } \\ \text { TPAO: } & \text { Turkish Petroleum Corporation } \\ \text { TÜPRAŞ: } & \text { Turkish Petroleum Refinery Corporation } \\ \text { tCO2e: } & \text { Tons of Carbon Dioxide Equivalents } \\ \text { TEDAŞ: } & \text { Turkish Electricity Distribution Company } \\ \text { TurkDex: } & \text { Turkish Derivatives Exchange } \\ \text { VAR: } & \text { Value-at-Risk } \\ \text { WTI: } & \text { West Texas Intermediate light sweet crude oil } \\ & \end{array}$




\section{INTRODUCTION}

The energy industry is global, rapidly expanding and becoming increasingly interdependent. Energy use is behind virtually everything a person does or touches. In developed countries, the increase in energy consumption indicates a reliance on energy and its related products for continued economic growth and development. At the same time, developing countries are reliant on the development of energy resources to drive their growth.

A global energy trading marketplace has also developed along with the growing worldwide demand for energy. Exchanges around the world are adding new energy trading products at a record pace. Many of these newly launched products help energy companies to offset various risks with each other. Individual energy firms are expanding their energy trading and risk management activities not only to help ensure continued and uninterrupted supplies of energy products for their consumers, but also to protect against economic shocks and political unease in some parts of the world.

Financial derivatives have been used historically by energy companies to engage in transactions to hedge their asset base and mitigate their financial exposures. At the same time, investment and commercial banks have used the energy financial markets either to speculate on the value of a certain commodity, or to offset their risks due to their business relationships with energy firms.

Historically, there has been minimal interaction between energy commodities, physically or geographically. While it is natural to consider that the production of oil or natural gas would include certain common business processes, ranging from extracting the commodity from the ground to distributing it to the ultimate customer, the relationships between the various energy products as they moved downstream were not necessarily linked. That has changed with the advent of the Internet and introduction of energy E-trading, which increased price availability and transparency. Instantaneous global communication and the ever-increasing demand for energy also contributed to the development of the global commodity trading marketplace. 
Despite all these movements, energy markets remain a relatively new world. In dealing with this extraordinary market environment we need all the skills and experience of other, more mature markets, plus some new ways of looking at market behaviors including via volatilities and price distributions. Our learning path in this research will begin with the energy markets, further encompassing study and research of market variables, with understanding the most specific properties of the market.

The main focus in first part of the research will be on the global markets of petroleum, natural gas, coal, electricity, weather and emission products which are used in the energy derivative markets. Also the financial risks of energy markets that result in the usage of derivative instruments will be analyzed here.

The second part of the research mainly will expose the types of energy derivative markets, the structure of energy instruments used in financial markets, the various properties of energy derivatives and their usage purposes. Furthermore, the weather derivatives, which have different specifications from other derivatives, will be covered in this part.

The third part of the research will be focused on the activity volume and structures of the world energy derivative markets in the regional basis. The impact of the energy E-Trade on the energy markets will be discussed here.

In the fourth and the last part of the research the historical growth and the recent condition of Turkish energy markets will be investigated and due to present position of derivative markets in Turkey the applicability of energy derivatives here will be evaluated. Finally, the correlation analysis between spot and futures oil prices, followed by the linear regression analysis will be applied on SPSS. 


\section{WORLD ENERGY MARKETS: ENERGY MARKET RISKS AND RISK MANAGEMENT}

Energy utilisation is crucial for modern society and world energy demand is growing constantly. In recent years, public interest in the energy sector has risen sharply with rapidly increasing oil prices, the liberalisation of energy markets, and the first noticeable effects of climate change caused by the burning of fossil fuels. Securing a reliable and sustainable energy supply in light of declining resources and climate change mitigation will be a key challenge of the 21 st century.

\subsection{PRIMARY ENERGY MARKETS}

In the future, energy will provide for the same needs as in the past - heat, light, cooling, lubrication, transportation, communication, mechanical power, and materials for war. How much will be needed and how it will be provided will vary. Although we would expect technological change that increases energy efficiency to reduce energy consumption, it may not, because of the rebound effect. An increase in energy efficiency will have two effects. As it lowers the amount of energy used to provide each unit of energy service, it will lower the cost of energy services and increase the amount of energy services purchased. ${ }^{1}$

Energy markets are a collection of commodities that are quite different in nature. It's helpful to break them into three groups. The first group is fuels - including oil, gas, coal, and their derivatives. The second is electricity and the final third group contains weather and emissions. This classification roughly corresponds to the historical pace at which these markets were opened. Fuel markets, and especially oil and gas markets, opened for competition in the 1980s at the wholesale level. Electricity markets

\footnotetext{
${ }^{1}$ Dahl, A. Carol, International Energy Markets: Understanding Pricing, Policies and Profits, Oklahoma: PennWell Corporation, 2004, p.36-37.
} 
followed in the early and mid-1990s. Finally, the late 1990s saw the quickening pace of trading in new types of commodities such as weather and emissions. ${ }^{2}$

The main primary energy source worldwide is oil covering $39 \%$ of worldwide energy consumption (Figure 1.1). Second are coal and natural gas each covering $24 \%$ of energy consumption. Nuclear energy $(6 \%)$ and others $(8 \%)$ have a much smaller share. ${ }^{3}$ Fears of instability in the supply of oil have precipitated considerable interest in nuclear, hydroelectric, and solar energy sources. However, crude oil still dominates the energy sector. $^{4}$

Figure1.1. World primary energy source consumption.

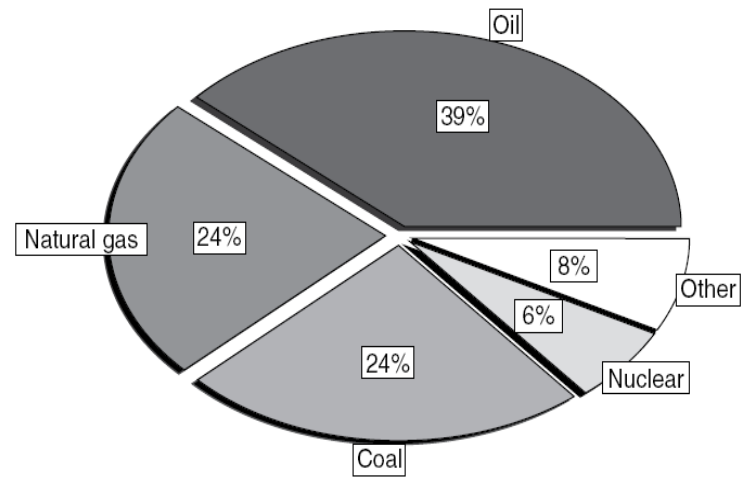

Total consumption: 420 quadrillion Btu

Source: Burger, M., Graeber, B., and Schindlmayr, G., Managing Energy Risk, Chichester: John Wiley \& Sons, Ltd. 2007, s.2

Worldwide energy consumption will continue to grow over the next decades. Depending on the economic growth scenario, the average annual growth rate of energy consumption is estimated between $1.5 \%$ and $2.6 \%$ with significant differences among the countries. In the reference scenario of $2 \%$ worldwide growth rate, non-OECD Asia (including China and India) grows at a rate of $3.7 \%$ per year whereas the OECD countries grow only at a rate of $1 \%$ per year. The rate of growth in world GDP - the

\footnotetext{
${ }^{2}$ Eydeland, Alexander and Wolyniec, Krzysztof, Energy and Power Risk Management: New Devolopments in Modeling,Pricing and Hedginig, New Jersey: John Wiley\&Sons, Inc. 2003, p.1.

${ }^{3}$ Burger, M., Graeber, B., and Schindlmayr, G., Managing Energy Risk, Chichester: John Wiley \& Sons, Ltd. 2007, p. 2

${ }^{4}$ Lewis, Nigel Da Costa, Energy Risk Modelling, Hampshire: PalgraveMacmillan, 2005, p.4.
} 
main driver of energy demand in all regions - is assumed to average 3.3\% per year over the period 2006-2030. It averaged 3.2\% from 1990 to $2006 .^{5}$

According to Reference Scenario of International Energy Agency (IEA), crude oil import price is assumed to average $\$ 100$ per barrel in real year-2008 dollars over the period 2008-2015 and then to rise in a broadly linear manner to over \$120 in 2030. In nominal terms, prices double to just over $\$ 200$ per barrel in 2030. Natural gas prices are assumed to rise in 2008 and then to fall back slightly through to 2010 in lagged adjustment to oil prices. Gas prices will rise after 2015 in line with oil prices. Coal prices, which have also risen sharply in recent years, are assumed to settle at around $\$ 120$ per tonne in 2010, remaining flat through to 2015 and then falling back slightly to $\$ 110$ in $2030^{6}$.

The market structures of various energy industries have evolved in different ways across time and countries. The coal industry in the world markets has remained fairly competitive, with the majority of coal sold under long term contracting. Electricity has evolved in a far different way. Once private or government-owned, vertically integrated monopolistic firms were the predominant form of market organization, but they are now privatizing and deregulating. Oil seems to have gone from cartel to cartel, with each cartel acting as a dominant firm until new suppliers weakened cartel hold on the market. The Texas Railroad Commission, the Seven Sisters, and OPEC have all had formal or informal agreements at one time to restrict output to maintain price ${ }^{7}$. Natural gas has evolved in different ways in different markets. In the early 1990s, the deregulation of the natural gas market in the United States led to a liquid and competitive gas market. In Europe, a developed natural gas market exists so far only in the UK, but the process of market liberalisation has also started in continental Europe.

Beginning in the 1970s, deregulation dramatically increased the degree of price uncertainty in the energy markets, prompting the development of the first exchangetraded energy derivative securities. The success and growth of these contracts attracted a broader range of participants to the energy markets and stimulated trading in an even

\footnotetext{
${ }^{5}$ World Energy Outlook, Paris: International Energy Agency, 2008, p.59.

${ }^{6}$ IBIT, p.59.

${ }^{7}$ Dahl,2004, p.169-170.
} 
wider variety of energy derivatives. Today, many exchanges and over-the-counter markets worldwide offer futures, futures options, swap contracts, and exotic options on a broad range of energy products, including crude oil, fuel oil, gasoil, heating oil, unleaded gasoline, and natural gas. ${ }^{8}$

Nowadays governments perform various policies in respect of either taxing or subsidiesing to influence energy markets. Energy-producing countries may find energy taxation a politically expedient source of revenues, particularly if a large part of the output is exported. They may use taxes to discourage energy use such as passing a carbon tax to discourage the use of high-carbon fossil fuels, which may cause global climate change. They may use differential taxes on energy products to influence industrial behavior such as Europe's high import taxes on oil products and low import taxes on crude oil imports to encourage refineries to be built in Europe rather than in the oil producing countries. Alternately, governments may subsidize rather than tax an energy product to encourage use, such as California subsidies on solar energy panels, or to protect a domestic industry and employment, such as Germany's subsidies to protect its domestic coal industry. ${ }^{9}$ Energy taxes and subsidies are able to distort prices and production in energy markets. Such distortions may decrease efficiency in efficient markets, or they may increase efficiency in inefficient markets.

\subsubsection{Oil Markets}

Oil, or petroleum, is a liquid fossil fuel formed when decaying plant life becomes trapped in a layer of porous rock. Depending on its origin, oil can be of different quality. The main characteristics are density and sulphur content. Fluid crude oils with low density have a lower specific weight and are called light crudes. With increasing density and specific weight the crudes are called intermediate and then heavy. Lighter crude oils are more valuable, since they yield more marketable products. Crude oils with a sulphur content of less than $1 \%$ are called sweet, otherwise they are

\footnotetext{
${ }^{8}$ Fleming, J. and Ostdiek, B., The Impact of Energy Derivatives on The Crude Oil Market, Energy Economics, Vol.21, Issue 2, April,1999, p.1-2.

${ }^{9}$ Dahl, 2004, p.65.
} 
called sour. Since a high sulphur content causes additional costs in the refinery process, sweet crude oils are priced at a premium. ${ }^{10}$

World liquid oil market has developed, using few reference oil qualities as benchmarks for pricing an individual oil quality. The most popular benchmark oils are:

- Brent: Reference for the North Sea oil market with a similar quality as WTI. Sulphur content: $0.3 \%$.

- West Texas Intermediate (WTI): Reference for the US market. Sulphur content: $0.3 \%$.

- Dubai: Reference for the Middle East and Far East markets. Sulphur content: $2 \%$.

Brent crude, a light, sweet North Sea oil, serves as an international pricing benchmark. As the original Brent crude stream has declined over the last decades, the Brent BFO index has been created combining Brent, Forties and Oseberg streams. Typical physical transactions for BFO crude oil are specified as FOB Sullom Voe.

Crude oil and petroleum product prices vary with world economic growth, weather and seasonal patterns, and regional refining and transportation capability. Crude oil prices have also been sensitive to international political events and to the production policies of the Organization of Petroleum Exporting Countries (OPEC). ${ }^{11}$

Extreme fluctuations are very inherent condition for historical oil prices. Before 1971, prices were stable because output was flexible. The few companies who then supplied most of the world governed output by shutting in their higher-cost sources. But after 1970, prices fluctuated widely. Even in the relatively stable decade

\footnotetext{
${ }^{10}$ Edwards, D.W., Energy Trading and Investing, McGraw-Hill, 2009, p.13-14

${ }^{11}$ Hale, Douglas R.; 2002, Derivatves and Risk Managemet in the Petroleum, Natural Gas and Electricity Industries, Washington: Energy Information Administration, p.16.
} 
1986-1997, oil prices were more volatile than other primary commodities, mostly metals. $^{12}$

Graph 1.1. Monthly average Brent spot prices (\$US/Barrel).

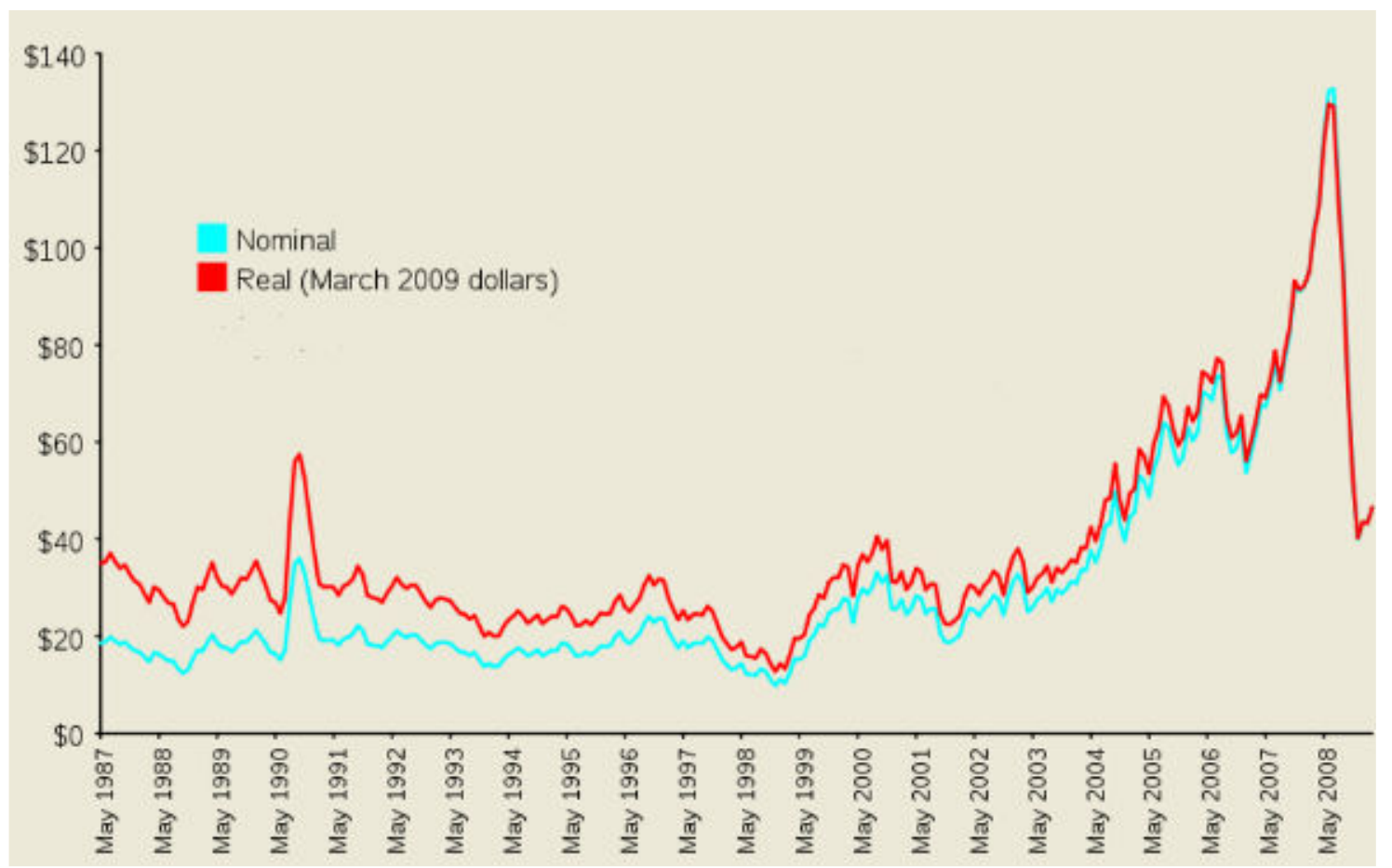

Source: International Energy Agency, 2009

A series of dramatic events in the 1970s such as the 1973 Yom Kippur war in the Middle East, the Iranian revolution of 1979 sent the price of oil from dwarfish $\$ 3 /$ barrel over $\$ 40 /$ barrel by the end of the decade, which would be over $\$ 100 /$ barrel in current prices. The price of crude oil spiked in 1990 with the uncertainty associated with Iraq's invasion of Kuwait. But following the Gulf War, crude oil prices entered a steady decline until 1994, when inflation-adjusted prices fell to their lowest levels since 1973. In the wake of the Asian financial crisis and a pick-up of Iraqi oil sales under the United Nations oil for-food program, oil prices plummeted to $\$ 10$ per barrel in late 1998. Then oil prices began to head sharply higher, due to global demand swell as the high-tech bubble encouraged a big investment boom in North America and Europe and as the

\footnotetext{
${ }^{12}$ Adelman, M. A.; 2002; "World Oil Production\&Prices 1947-2000" Quarterly Review of Economics and Finance, Vol.42, Issue 2, June, p.171.
} 
Asian economies began to recover. OPEC was either unable or unwilling to match increased demand by raising output. By the middle of 2000 , oil prices tripled. ${ }^{13}$

The price remained very volatile after the collapse in the 1980s, but was still as low as \$20/barrel in 2001. In 2002 uncertainties of Iraq-USA war caused extreme fluctuations in crude prices, but OPEC's decision to raise the output mitigated this situation. The next 5 years saw a steady increase that tripled the real price by the middle of 2007. Later that year, the path of oil prices steepened sharply, sending the price to the highest of $\$ 145 /$ barrel on July 3, 2008, only to be followed by an even more spectacular price collapse. $^{14}$

The oil market risk management was quite poor organized until 1980s. Only such hedging tools as ten-year fixed-price supply contracts have been commonplace in the over-the-counter market for many years, swaps where oil at a fixed price was exchanged for oil at a floating price. ${ }^{15}$ After the collapse of the OPEC-administered pricing system in 1985, and a short lived experiment with netback pricing, oil-exporting countries adopted a market-linked pricing mechanism. This led to the creation of active forward and spot markets. Today the crude oil market is the largest commodity market in the world. The most significant trading hubs are New York, London, and Singapore. The liquidity in those markets varies substantially. ${ }^{16}$

The World oil trade transactions are based on U.S. dollars. All the changes occurring in the dollar price consequently affects the oil price. So producers have to react in increasing oil prices due to falling dollar prices.

As of 2008, the world's proven oil reserves were approximately 1,258.5 thousand million barrels, of which 955.8 billion were located in Organization of

\footnotetext{
${ }^{13}$ Kubarych, Roger; 2005, "How Oil Socks Affect Markets,” International Economy, Vol.19, Issue, 3, p.33-35.

${ }^{14}$ Hamilton, James, Causes and Consequences of the Oil Shock 2007-2008, Brookings Papers on Economic Activity, 2009, p. 4-8.

${ }^{15}$ Hull, John C., Options, Futures and Other Derivatives, Fifth Edition, New Jersey: Prentice Hall, 2003, p. 680.

${ }^{16}$ Eydeland, Alexander and Wolyniec, Krzysztof; Energy and Power Risk Management: New

Devolopments in Modeling,Pricing and Hedginig, New Jersey: John Wiley\&Sons, Inc. 2003, p.3
} 
Petroleum Exporting Countries (OPEC). ${ }^{17}$ By comparison, in 1987 and 1997 proven reserves were 910.2 thousand million barrels (676 thousand million barrels from OPEC) and 1069.3 thousand million barrels (818.7 thousand million barrels from OPEC). Between 1987 and 2007, oil reserves increased 36 percent. OPEC countries account for 75.5 percent of all proven oil reserves.

The oil production is continually increasing over the time. In 1995 the world produced 62.38 million barrels of crude oil per day. Over the next ten years, crude oil output increased 18.31 percent to 73.81 million barrels per day. Production decreased to 73.54 million barrels per day in 2006, then reaching a number 81.82 million barrels per day in 2008.

The United States is the largest consumer of crude oil in the world. In 2008, it consumed 19,419 thousand barrels of oil per day, representing 23 percent of the world's total oil consumption. However, U.S. consumption was actually 5 percent lower in 2008 than in 2007. By comparison, China, the world's second largest consumer, used 7,999 thousand barrels of oil per day in 2008, or 41 percent of U.S. demand, 10 percent of the world's total production. This represents an increase by 3.3 percent, compared to $2007 .^{18}$

Different scenarios for the world's economic growth assume an average annual growth rate of $0.9 \%$ to $2.0 \%$ for the world's oil consumption. This means that in 2030 , global oil consumption is estimated to be between 103 and 137 million barrels per day compared to 85 million barrels in 2008. Most of the projected increase in world oil supply comes from OPEC countries, which hold the majority of the world's remaining reserves of conventional oil. Their share of global output will rise from $44 \%$ in 2007 to $51 \%$ in 2030 . Oil prices are assumed to fall from the 2008 level of $\$ 97$ per barrel to around $\$ 60$ per barrel in 2009 , but then rebound with the economic recovery to reach $\$ 100$ per barrel by 2020 and $\$ 115$ per barrel by 2030 (in year-2008 dollars). ${ }^{19}$

\footnotetext{
${ }^{17}$ BP Statistical Review of World Energy, June, 2009, p. 6.

${ }^{18}$ Foundations of Energy Risk Management, GARP, New Jersey: John Wiley\&Sons, Inc, 2009, p. 36.

${ }^{19}$ World Energy Outlook, 2009.
} 


\subsubsection{Natural Gas Markets}

Natural gas is a fossil fuel used for heating and producing electricity. It is a combination of colorless, odorless gases composed primarily of methane $\left(\mathrm{CH}_{4}\right)$. It is often found mixed with nitrogen, carbon dioxide, and other trace gases. Natural gas is considered "dry" when it is almost pure methane, and "wet" when it has substantial quantities of the other hydrocarbons. ${ }^{20}$ LNG is a liquid state of natural gas under pressure. LNG provides a convenient and cost-efficient method of transporting gases over long distances.

Natural gas production started as a byproduct of crude oil. Natural gas has now become an attractive fuel for home heating, industrial use, and, more recently, power generation because it burns efficiently and cleanly. A major impediment to natural gas distribution is the geographic isolation of natural gas fields. The natural gas market is a collection of locations at which the delivery and receipt of the commodity takes place. The participating parties contract for two services - "delivery and receipt of natural gas at a given location" and "transportation of natural gas between two different locations".

Depending on their position in the pipeline system, these locations experience different volumes of transactions. Some locations have developed into significant trading hubs. In the eastern United States the major location is Henry Hub in southern Louisiana. The western United States has its main trading hub at Waha Hub in west Texas. $^{21}$

Except the UK, where a liberalised market for gas exists, the market in continental Europe is still dominated by long-term contracts indexed to oil prices. The most important gas trading hubs in Europe are The National Balancing Point (NBP) in the UK, Zeebrugge in Belgium and Title Transfer Facility (TTF) in Netherlands. Japan and South Korea cover most of the gas demand through LNG mainly from Indonesia, Malaysia, Australia and the Middle East. This market is dominated by long-term contracts linked to crude oil prices. A typical formula, used in Japan, is $\mathrm{P}=\mathrm{A}+\mathrm{B} \times \mathrm{JCC}$,

\footnotetext{
${ }^{20}$ Edwards, 2009, p. 5.

${ }^{21}$ Eydeland, 2003, p. 4.
} 
where A and B are constants and JCC is the Japan Crude Cocktail, a particular basket of crudes. $^{22}$

The natural gas markets were steadily opened to competition during the $1980 \mathrm{~s}$ and early 1990s which are driven by supply and demand. After the deregulation and elimination of state monopolies the supplier of natural gas is now not necessarily the same company as the producer of the gas. Suppliers are faced with the problem of meeting daily demand. Initially, only typical over-the-counter contracts were available for the delivery of a specified amount of natural gas at a roughly uniform rate over a one-month period. There was no standard long-term contract for gas marketing and contractual relationships were highly personalized. However, with huge increases in volume, long-term gas contracts have become more standardized, and since the market demands flexibility in pricing, few contracts contain fixed prices. By 1995, 90\% of marketers' purchase contracts were indexed. To maintain allocative efficiency, these prices are usually indexed to factors that reflect current market conditions, such as NYMEX natural gas futures prices or published spot price indexes. High-price volatility led to the development of a gas futures market to moderate price uncertainty, and marketers handled much of their risk management this way. Market hubs developed rapidly to provide services formerly offered by the pipelines, and storage increased to help provide reliable service that pipelines had formerly offered. ${ }^{23}$

Like many other energy products, the forward and spot markets for natural gas are distinct from one another. There is an extremely well defined seasonal component to forward prices. Prices in the forward market tend to mirror consumer demand - both are high in the winter and fall dramatically in the spring of every year. Spot prices don't show the same kind of seasonality. However, despite the different behaviors, arbitrage between the two markets is impossible without a physical storage facility. It is possible to make a profit buying gas on the spot market, storing it, and selling it for future

\footnotetext{
${ }^{22}$ Burger, 2007, p.12-14.

${ }^{23}$ Dahl, 2004, p. 193-197.
} 
delivery. However, this requires an ability to make physical trades - to take delivery and store large quantities of a gas - which many market participants lack. ${ }^{24}$

Outside the U.S. and some European countries there is not such an advanced market for natural gas as the world oil markets, so the agreements and prices generally remain hidden. Natural gas trade agreements are maintained in the form of bilateral contracts between countries. In the majority of international and domestic natural gas purchase contracts prices are determined in a private and confidential manner rather than declared bill rates. ${ }^{25}$

Graph 1.2. Monthly average NYMEX Henry Hub Gas Futures prices (\$US/MMBTU).

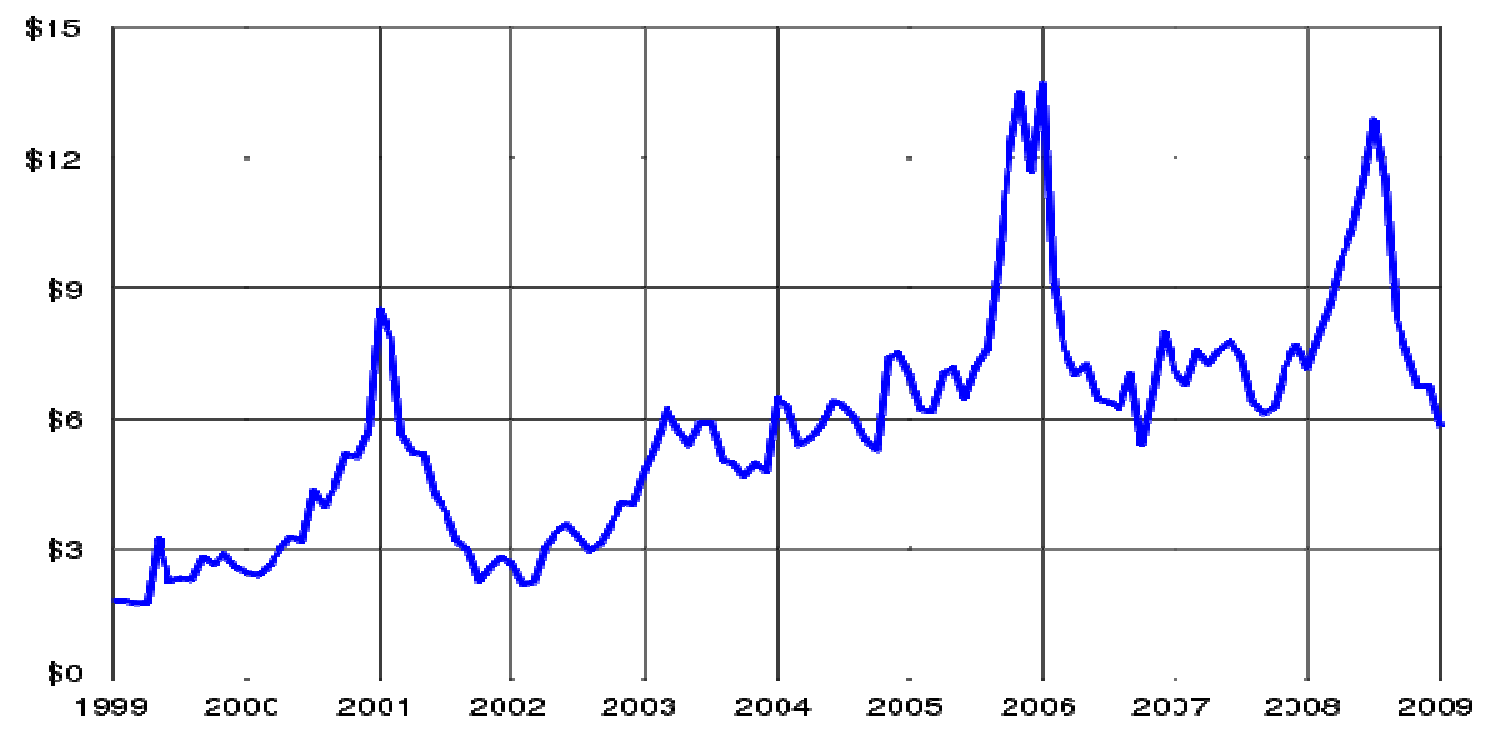

Source: http://ww.nymex.com, 2009

Historically, natural gas prices were cents per thousand cubic feet. After crude oil prices became market sensitive in the early 1970s, it was not until natural gas prices were decontrolled that gas in interstate commerce came up to realistic prices ranging from over a dollar to $\$ 5-6 /$ MMBTU. Gas prices during the 1970s, before decontrol, for the intrastate market quickly came to market sensitive levels of \$3 to \$6/MMBTU. The high price for natural gas after decontrol was an affect of the legislation, which set up

\footnotetext{
${ }^{24}$ Edwards, 2009, p.6.

${ }^{25}$ Bayraç, Naci H.; Dünyada ve Türkiye' de Doğal Gaz Piyasasının Ekonomik Analizi, 1999, p.3
} 
about a dozen pricing categories. When the gas surpluses of the mid-1980s started, where the legislation had set the "maximum lawful price," it did nothing for a minimum price. The gas merchants of that time, the pipelines, brought the prices down to the \$2/MMBTU range quickly. Since 1985 until now, natural gas prices have varied from around a $\$ 1 /$ MMBTU to current highs above $\$ 12 / \mathrm{MMBTU}$. The main price benchmark for natural gas is NYMEX Henry-Hub futures contract.

The price for natural gas at the burner tip is dependent on many things market conditions, supply/demand balances, economic conditions, and many more including the activity of natural gas financial markets, prices for competing fuels, etc.

In looking at gas prices, it is necessary to know where the gas is sold as prices vary according to where the sale is made in the wellhead to consumer path. Its value does increase as it moves through the system going from the wellhead to the consumer because of the added value of the transportation and services bringing the gas to market. Natural gas has three major pricing points. The first points would be the wellhead or field price which the pricing at a central location after the gas is gathered in the field. The next point would be the into pipe price where the gas goes into a pipeline for transportation to the marketing area or to a "hub". From the hub pricing, gas would then be priced at the city gate where it is transferred to a local distribution company for delivery to the consumer. The pricing for the consumer would be based on the "sales point" price, which would be a total price for the gas including all the transportation and services. $^{26}$

The world had 106.86 trillion cubic meters of proven natural gas reserves in 1987. By 1997, world proven natural gas reserves stood at 146.46 trillion cubic meters and increased to 185.02 trillion cubic meters by 2008 .

In 2008, the world produced 3.07 billion cubic meters of natural gas. The Russian Federation was the world's largest natural gas producer, producing $19.6 \%$ of the world's natural gas needs in 2008. The United States was second with $19 \%$ of the world's production, and Canada a distant third, producing $6.7 \%$ of the world's gas.

${ }^{26}$ Freedenthal, Carol, Natural Gas Purchasing, The Fairmont Press, Inc., 2007, p. 564-570. 
The United States is the largest consumer of natural gas in the world. In 2008, it consumed 657 billion cubic meters of natural gas, representing 22 percent of global natural gas usage. By comparison, the second largest consumer of natural gas, the Russian Federation, consumed 420 billion cubic meters of natural gas, or 14 percent of global natural gas usage. Natural gas consumption has been reasonably stable in North America, but is growing in Europe and Asia. ${ }^{27}$

In the Reference Scenario of IEA, global gas demand rises from 3.0 trillion cubic metres in 2007 to 4.3 trillion cubic metres in 2030 - an average rate of increase of $1.5 \%$ per year. Most of the growth in gas exports over 2006-2030 comes from the Middle East and Africa. Together, they account for about $60 \%$ of total exports in 2030. Russia and the Caspian/Central Asian countries combined remain the other main exporting region. Most of the increase in inter-regional trade is in the form of LNG, its share of trade rising from $52 \%$ in 2006 to $69 \%$ in $2030 .{ }^{28}$

\subsubsection{Coal Markets}

Coal is a combustible, sedimentary, organic rock, which is composed mainly of carbon, hydrogen and oxygen. It is formed from vegetation, which has been consolidated between other rock strata and altered by the combined effects of pressure and heat over millions of years to form coal seams ${ }^{29}$

Characteristics defining coal quality are its carbon, energy, sulphur, and ash content. The higher the carbon content of a coal, the higher its rank or quality. These characteristics determine the coal's price and suitability for various uses. There are three main categories of coal. These are hard coal, sub-bituminous coal and lignite. Hard coal has the highest gross calorific value - greater than $23865 \mathrm{~kJ} / \mathrm{kg}(5700 \mathrm{kcal} / \mathrm{kg})$. There are two types of coal by its industrial usage - steam coal and coking coal. ${ }^{30}$

\footnotetext{
${ }^{27}$ BP Statistical Review of World Energy, June, 2009, p. 6.

${ }^{28}$ World Energy Outlook, 2008, p.189.

${ }^{29}$ World Coal Research: A Comprehensive Overview of Coal, World Coal Institute (WCI), 2005, p.2.

${ }^{30}$ Burger, 2007, p.16
} 
Coal is easy to store and relatively inexpensive to produce relative to the amount of electrical power it can generate. In many ways it is the perfect fuel. Unfortunately, it is a major source of carbon $\left(\mathrm{CO}_{2}\right)$ and sulfur $\left(\mathrm{SO}_{2}\right)$ emissions. The pollution that results from burning coal has made it unpopular among consumers. Because the price of coal is generally low, transportation makes up a much higher percentage of the delivered cost than of other fossil fuels. As a result, most coal is used within a couple hundred miles of where it is mined. By far the biggest application for coal is electrical generation. Electrical power plants and coal mining companies are often located close together. As a result, there are relatively few people buying or selling coal on the open market. Coal is important to electrical generation, but not a heavily traded financial product by itself. ${ }^{31}$

Coal-fueled power plants burn coal to generate the steam that turns the turbines producing electricity. Coal plays a vital role in power generation, and this role is set to continue. Coal currently fuels 40 percent of the world's electricity, and this proportion is expected to remain at similar levels over the next 30 years. Consumption of steam coal is projected to grow by 1.5 percent per year over the period 2002-2030. Lignite, also used in power generation, will grow by 1 percent per year.

Coal is an input to making steel by baking it in hot furnaces to make coke. Coke is then used to smelt iron ore into iron needed for making steel. It is the very high temperatures created from the use of coke that gives steel the strength and flexibility for products such as bridges, buildings, and automobiles. Demand for coking coal in iron and steel production is set to increase by 0.9 percent per year over this period.

The coal market is dominated by long-term delivery contracts between producers and generators. Most coal trades are OTC trades. There is an over-the-counter spot market, and by 2001 a coal futures markets started with NYMEX. The application of coal derivatives contracts in exchanges provides some advantages to investors, mainly allowing them to hedge against different market risks. Coal derivative contracts ensure a development of price transparency in the market and contribute to a creation of

${ }^{31}$ Edwards, 2009, p.26-28 
reliable reference prices such as Central Appalachian Coal Futures or Western Rail Powder River Basin (PRB) Coal Swaps references.

Financial swaps are the most common product for risk management for both coal producers and consumers. However, because physical coal always has specific characteristics, physical coal trading is not as straightforward as trading financial swaps. The swap market is therefore particularly interesting for financial institutions, which are active market players. Financial swaps are traded usually up to three years in the future, while the time period for physical coal trading is usually shorter.

Over 6,395.6 million tones of coal is currently produced worldwide. This is a 38 percent increase over the past 20 years. Coal production has grown fastest in Asia, while Europe has actually seen a decline in production. The largest coal-producing countries are not confined to one region - the top five producers are China, the United States, India, Australia and South Africa. Much of global coal production is used in the country in which it was produced; around 18 percent of hard coal production is destined for the international coal market. Global coal production is expected to reach 7 billion ton in 2030 - with China accounting for around half the increase over this period. Steam coal production is projected to have reached around 5.2 billion ton, coking coal 624 million ton and brown coal 1.2 billion tons. ${ }^{32}$

Coal prices have kept pace with increases in oil and natural gas prices in recent years. The spot price of steam coal delivered to ports in Europe and Asia rose to above $\$ 100$ per tonne in 2008. Coal supply costs have also risen dramatically, due to sharp increases in the cost of materials, equipment, diesel, labour and shipping. Projected cumulative investment in coal-supply infrastructure totals about $\$ 730$ billion between 2007 and 2030 (in year-2008 dollars), 91\% of which is required for mines, and the rest for ports and shipping. ${ }^{33}$

\footnotetext{
${ }^{32}$ Foundations of Energy Risk Mangement, 2009, p. 52

${ }^{33}$ World Energy Outlook, 2008, p.123.
} 
Graph 1.3. Historical spot prices of Central Appalachian and Northwest Europe coal benchmarks (\$US/tonne).

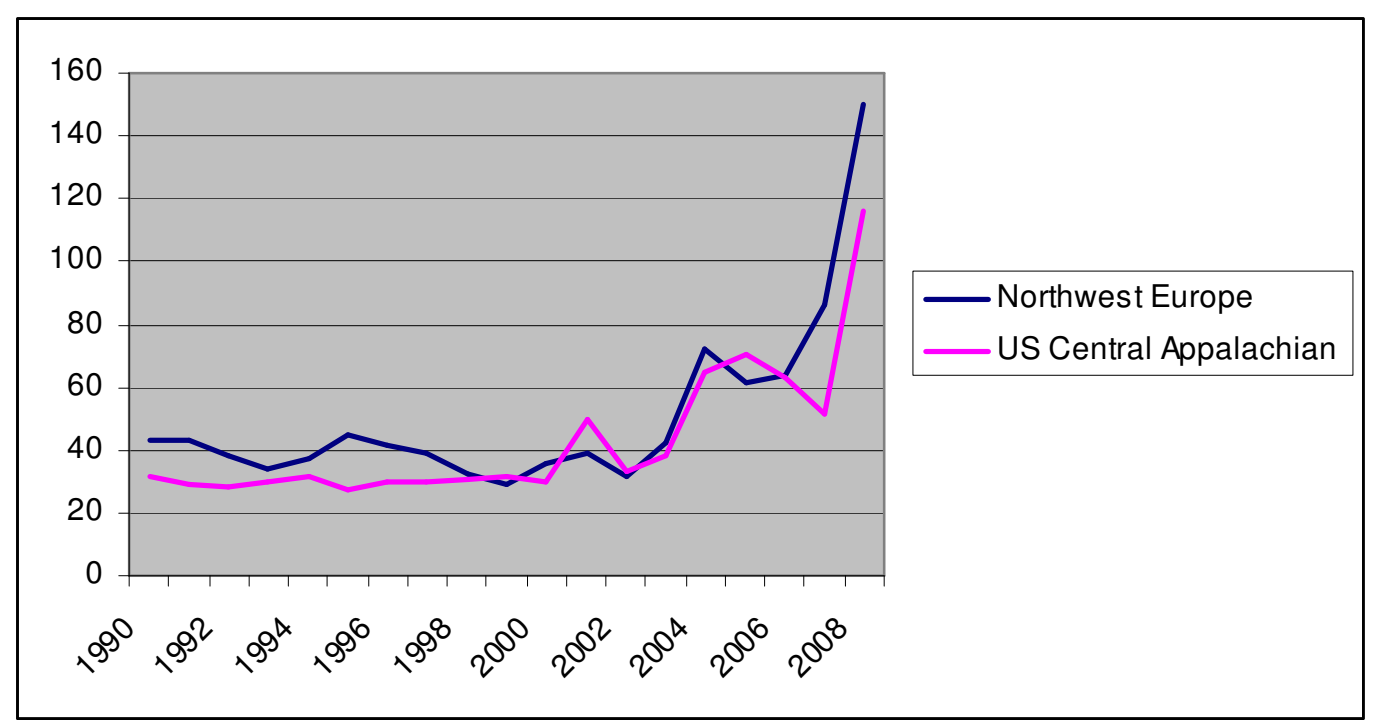

Source: BP Statistical Review of World Energy, 2009

Coal is traded all over the world, with coal shipped huge distances by sea to reach markets. Over the last twenty years, seaborne trade in steam coal has increased on average by about $8 \%$ each year, while seaborne coking coal trade has increased by $2 \%$ a year.

The volume of international physical coal trading in 2004 was 693 million tonnes. In 2005, this increased to 775 million tonnes with around $90 \%$ of this being seaborne trade. While this is a significant amount of coal it still only accounts for about $18 \%$ of total coal consumed. Australia is the world's largest coal exporter; exporting 234 million tons of hard coal in 2005, out of an annual capacity of 270.5 million tons. There are two main trading regions, the Atlantic and the Pacific region. South Africa, Columbia and Russia are the main coal suppliers for the Atlantic region and Indonesia, Australia and China for the Pacific region. There is also a small interexchange with Australia and Indonesia supplying both the Pacific and the Atlantic region.

Carbon dioxide emissions from coal combustion are set to rise from 11.7 gigatonnes in 2006 to 18.6 gigatonnes in 2030, driving up coal's share of total emissions from $42 \%$ to $46 \%$. 


\subsubsection{Electricity Markets}

Electricity is a form of energy used for a very wide range of applications. It is easy to control, non-polluting at the location of its usage and convenient. It is used in the application of heat, light and power. As a secondary energy source electricity is generated from the conversion of other energy sources, like coal, natural gas, oil, nuclear power, hydro power and other renewable sources. This implies that electricity markets and electricity prices are fundamentally linked to markets for primary fuels and environmental conditions.

Over the last decade, electric markets have been significantly restructured throughout the world. This is a process of breaking up vertically integrated electricity utilities and introduction of commercial interfaces between the functions of generation, transition, distribution and retailing of electrical energy. The motivation for restructuring is to harness a pressure to improve the economic efficiency of electricity industry, to contribute to the environmental protection and to provide a better service for energy consumers. However, the competition in electricity production and trading raises various problems concerning optimal market design, risk estimation, and strategy optimization for power producers and retailers. ${ }^{34}$

The electricity cash market takes on two contracting structures: pools and bilateral markets. The main characteristic of the pool market is the formal establishment of the market (system) clearing price at which all cash energy transactions clear. Examples include the Nordic Power Exchange (Nord Pool), New England Power Pool (NEPOOL), New York Intrastate Access Settlement Pool (NYPOOL), and the California Independent System Operator (CAISO). In bilateral markets transactions are entered into by two parties and are independent of any other transactions in the market. Examples include the Electric Reliability Council of Texas (ERCOT), the East Central Area Reliability Council (ECAR), and the Southeastern Electric Reliability Council $(\mathrm{SERC}){ }^{35}$

\footnotetext{
${ }^{34}$ Hinz, Juri, Challenges in Pricing of Electricity Risk, 2004, p.1.

${ }^{35}$ Eydeland, 2003, p.6
} 
The electricity spot market can be divided into two categories - day ahead and intra-day markets. In the day ahead market products are traded which are delivered the next day. Day ahead products are the most common spot products and can be traded either on a power exchange or as a bilateral agreement. Day ahead products are the underlyings of the futures contracts on the power exchange. The intra-day market is for products with a delivery on the same day. This market allows the producers a short-term load dependent optimisation of their generation. Because this market serves the direct physical supply it is not a market for pure trading purposes. Intra-day products are traded either on a power exchange or bilaterally. ${ }^{36}$

A deregulated electricity market consists at least of two parts: of the balancing market for contracts on the immediate electricity production and of the electricity exchange for those on the future delivery. Within the last segment, a remarkable trading activity is observed for hourly contracts with delivery within the following day, at the spot-market. The market for other forward contracts is referred to as futures market. Another notable market is for contracts on availability of a free production capacity or its financial counter parts, both usually traded over the counter. ${ }^{37}$

The core challenge in the energy industry is to balance energy supply with energy demand or consumption. Electricity cannot currently be economically stored in meaningful quantities. This means that it is not possible to generate large amounts of electricity at times of low demand and put it aside for use later at times of high demand. Consequently, electricity has to be generated at the same time as it is consumed. To ensure that demand can be met at all times, therefore, it is necessary to have available enough generating capacity to meet the highest expected level of demand. This means, however, that during much of the time some capital is sitting idle. ${ }^{38}$

The load cycle for electricity varies through the day and the year. There is daily peak and off-peak demand. Peak tends to occur during the day and early evening; shoulder production, early in the morning and later in the evening. Off-peak occurs during the night. There are also seasonal peaks and off-peaks depending on the climate and daylight

\footnotetext{
${ }^{36}$ Burger, 2007, p.28-29

${ }^{37}$ Hinz, 2004, p. 2

${ }^{38}$ Energy Markets Outlook, 2007, p.19.
} 
hours. ${ }^{39}$ Peak-load pricing in electricity markets means charging different prices for electricity depending on the load factor.

Graph 1.4. Hourly Price of Electricity in USD, PJM, April 1-8, 2008

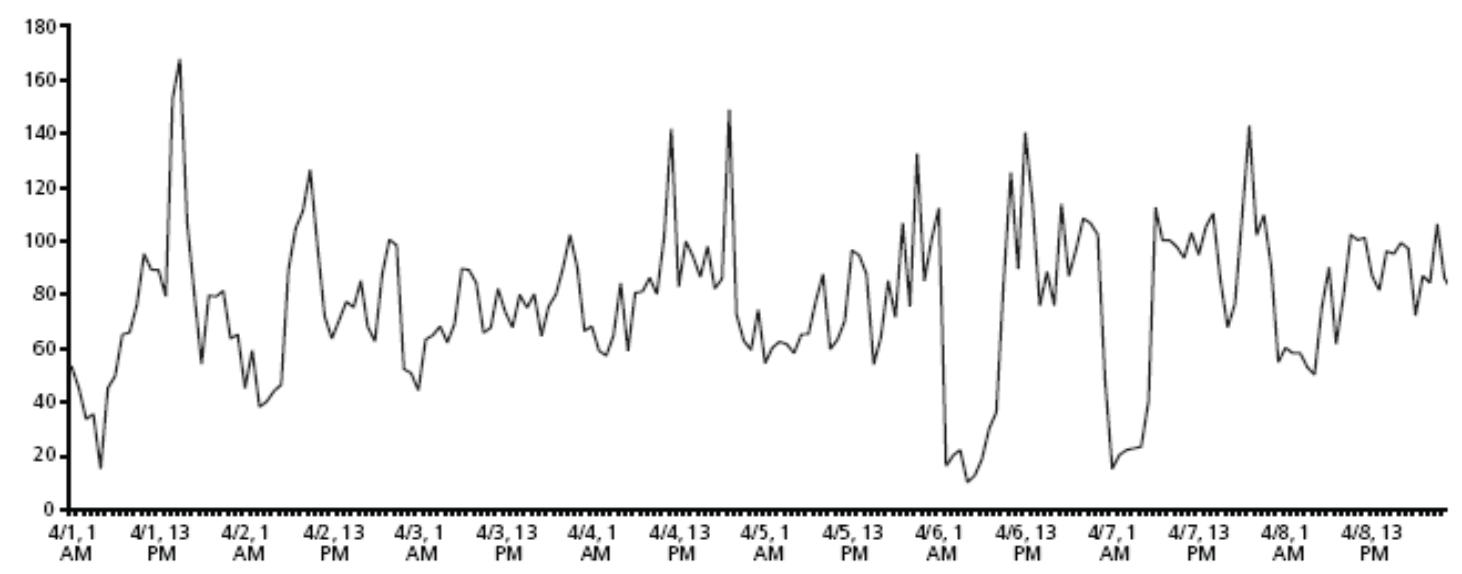

Electricity deregulation appears to be creating some convergence between the electricity and natural gas markets. Numerous mergers have joined gas and electric power producers. Some countries have programs to promulgate retail choice, which will encourage further changes in the electric and gas industries.

Like natural gas, electricity markets deregulation has been accompanied by the development of an electricity derivatives market. NYMEX now trades a futures contract on the price of electricity and there is an active OTC market in forward contracts, options, and swaps.

\subsubsection{Emission Markets}

Carbon emission trading has been steadily increasing in recent years. According to the World Bank's Carbon Finance Unit, 374 million metric tons of carbon dioxide equivalents $\left(\mathrm{tCO}_{2} \mathrm{e}\right)$ were exchanged through projects in 2005, a 240 percent increase relative to 2004 . With the creation of a market for mandatory trading of carbon dioxide emissions within the Kyoto protocol, financial markets in London have established themselves as the center of the carbon finance market. Active trading

${ }^{39}$ Dahl, 2004, p.106-108 
programs exist for several pollutants. Carbon trading is emission trading specifically for the right to emit carbon dioxide. Emissions are calculated in tons of carbon dioxide equivalent or $\mathrm{tCO}_{2} \mathrm{e}$. Currently, carbon trading makes up the bulk of emission trading. ${ }^{40}$

\section{Graph 1.5. Emission factors of various fuels}

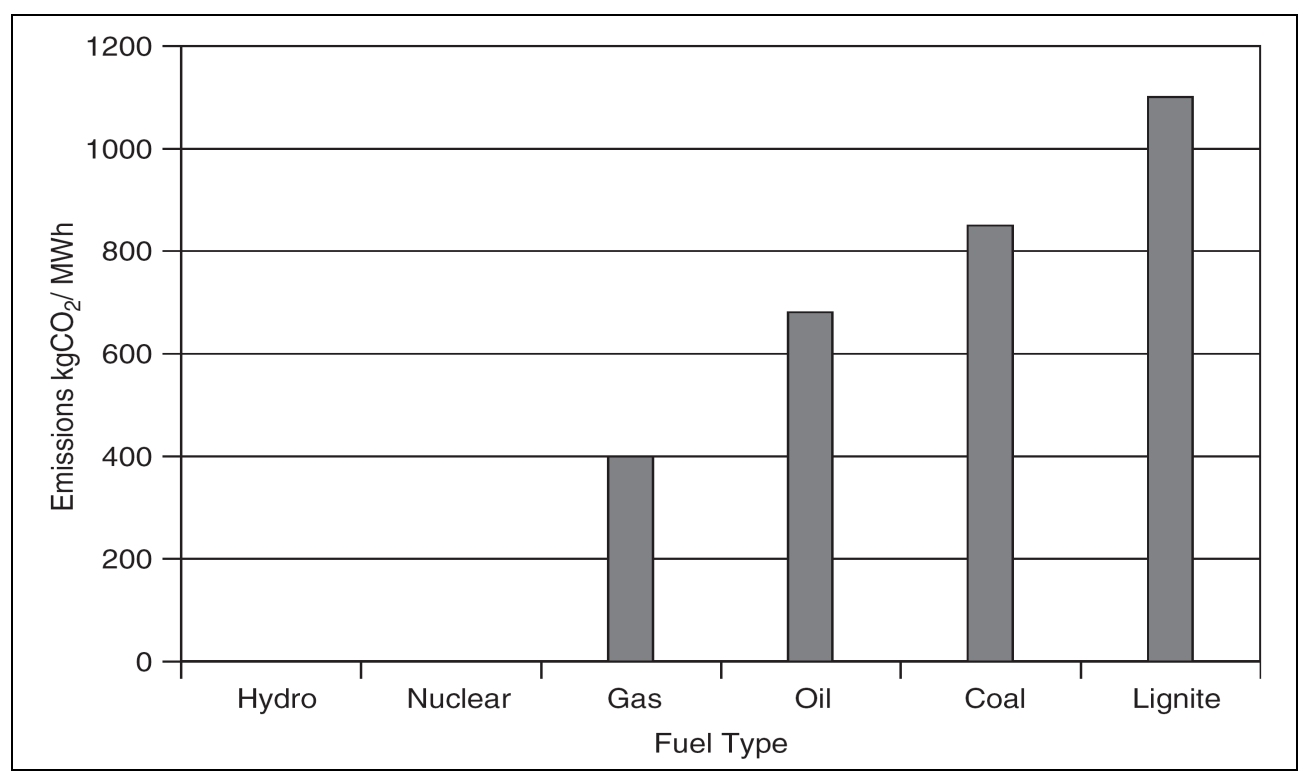

Source: Climate Change and the Power Industry, PricewaterhouseCoopers and Enerpresse, 2002.

The core of the Kyoto agreement is the creation of a cap-and-trade system that imposes both international and national limits for greenhouse gas emissions ${ }^{41}$. All EU member states have ratified the Kyoto Protocol. The United States is the only industrialized nation that has not ratified the treaty and is not bound by it. Each participating country agreed to emission quotas. Their intention is to reduce overall emissions to 1990 levels by the end of 2012. Under the treaty, countries that emit less than their quota will be able to sell emissions credits to nations that exceed their quota. The treaty makes it possible for developed countries to sponsor carbon projects that provide a reduction in greenhouse gas emissions in other countries, as a way of generating tradeable carbon credits.

\footnotetext{
${ }^{40}$ Foundations of Energy Risk Management, 2009, p.87

${ }^{41}$ Edwards, 2009, p.161
} 
There are two ways to get emissions credits (rights) in most cap-and-trade systems. The first is to receive the right from the administrator of the cap-and- trade system. Usually these rights are allocated or auctioned off. The other way is to create something that offsets carbon emissions in some manner. This might be through creating a carbon sink (like planting a forest), capturing carbon dioxide emissions and storing them underground, or by creating a nonpolluting source of electricity (building a hydroelectric plant or solar power installation). Particularly under cap-and-trade systems conforming to the Kyoto Protocol, it is possible to offset carbon emissions anywhere around the world. This ensures that the lowest cost alternative can be found ${ }^{42}$.

Main products on the market are EU Allowances (EUAs) for the first trading period 2005-2007 and for the second trading period 2008-2012. EUA spot and forward contracts as well as options are traded bilaterally (OTC or via brokers). Spot and futures trading is possible at several exchanges. Options are traded at exchanges as well, but the liquidity is very low. Main European emission exchanges are European Climate Exchange (ECX) in Amsterdam, European Energy Exchange (EEX) in Leipzig, Energy Exchange Austria (EXAA) in Vienna, NordPool in Oslo and PowerNext in Paris.

Regarding $\mathrm{CO}_{2}$ emissions, the cap-and-trade approach has not been implemented as a mandatory scheme in US so far. The only greenhouse gas emissions trading scheme operational in the United Stated is the Chicago Climate Exchange $(\mathrm{CCX})$, a voluntary programme that allows municipal, corporate and other partners to accept a common reduction target for $\mathrm{CO}_{2}$ and other greenhouse gas emissions under the Kyoto Protocol. ${ }^{43}$

\subsection{RISKS IN ENERGY MARKETS}

Risk management is the process of achieving the desired balance of risk and return through a particular trading strategy. All quantitative and managerial objectives and tactics should be guided by the desired balance of risk and return. The risk/return framework incorporates the full business process of selecting, communicating, valuing, and achieving this balance within the firm's portfolio of assets. The risk identification

\footnotetext{
${ }^{42}$ Edwards, 2009, p. 163-164

${ }^{43}$ Burger, 2007, p.46
} 
and selection process is extremely important. Ignoring any risk does not make it go away. In fact, market experience proves that large market risks will indeed catch up with you if you wait long enough.

\subsubsection{The Aim of Risk Management}

The scale of risks facing energy market participants is unprecedented. In this light, the importance of proper managing, or at minimum proper understanding, of the risks is critical for one's ability to make proper investment, operational, and contractual decisions. It is an established fact that in the financial markets there are no excess returns without risk, while a zero risk tolerance would result in zero excess returns. Risks must be taken, implying that some losses cannot be prevented. The goal of risk management is to monitor those risks and to contain those losses within pre-specified tolerances. The numerous examples of firms that have suffered because of lacking risk management skills, like Barings, Metallgesellschaft and Orange to mention a few, show how costly it can be when risk management is not taken seriously.

A firm that does not have its risks under control will have a greater probability to default. If the firm would default it would cause problems for all parties that have connections with the firm, the so-called stakeholders. In all cases the stakeholders will demand something for this uncertainty, a so-called risk premium. Well functioning risk management procedures within the firm can avoid or decrease this costly risk premium and hence improve the profitability. ${ }^{44}$

\subsubsection{Types of Risks in Energy Markets}

For energy companies, some of the main predictable and quantifiable risks are market risk, credit risk, cash flow risk, liquidity risk, political risk, operational risk, basis risk and model risk.

Market or Price risk - the risk to a firm's financial condition arising from adverse movements in the level or volatility of market prices. With constantly changing

\footnotetext{
${ }^{44}$ Unger, Gustaf, Hedging Strategy and Electricity Contract Engineering, 2002, p.46
} 
crude and natural gas prices, buyers and sellers may not get the best price for their product or may miscalculate demand or pricing, causing material adverse effects. ${ }^{45}$ Broadly speaking, market risk refers to changes in the value of financial instruments or contracts held by a firm due to unpredictable fluctuations in prices of traded assets and commodities as well as fluctuations in interest and exchange rates and other market indices. $^{46}$

Credit or Default risk - the risk that a counterparty is not able to make payments as agreed for the goods or services provided. It is often said that a hedge contract is only as reliable as the credit standing of the counterpart. The credit crunch felt in the USA energy sector in the aftermath of the Enron disaster has prompted energy traders to review credit policies and also review effective methods to control and reduce credit risk wherever possible ${ }^{47}$.

Cash flow risk - the risk that an organization will not be able to produce the cash to meet its derivatives obligations. In the late 1990s, Korean Airlines found itself in this kind of situation and suffered heavy losses as a result. The company had been hedging against movements in the jet fuel price by using derivatives which were denominated in dollars. When the Korean won suddenly fell in value against the dollar, the company found that the cost of the dollars needed to service its derivatives contracts had soared. The company lost out because it had not hedged against the risk of a negative movement in the currency differential between the won and the US dollar.

Liquidity risk - the risk of not being able to trade in the market due to lack of counterparties. Liquidity refers to the ease and certainty by which a financial instrument can be converted into cash. Liquidity is also used by credit managers to describe one's ability to meet financial obligations. Liquidity risk is important to parties who are about to trade physical commodities or financial derivatives. Liquidity risk is perhaps more of an issue in over-the-counter than exchange-traded transactions. This is because market-

\footnotetext{
${ }^{45}$ Unger, 2002, p. 48

${ }^{46}$ Pezier, Jacques, Market Risk Management, PRMIA III.A.1, 2004, p. 1

47 James, Tom; Energy Price Risk, First Published, New York: Palgrave Macmillan, 2003, p.2.
} 
makers for exchange-traded instruments are required to show prices to their customers at all times. ${ }^{48}$

Political and Regulatory risk - changes in value due to unexpected political decisions or unexpected regulatory intervention. Energy companies are particularly sensitive to political or regulatory changes, as these companies often have a high profile, and make significant long-range investments in exploration, production, transportation, and distribution. In these activities, companies follow the regulatory framework that various government agencies impose. Changes in political conditions, often by a new government, can change established rules - such as labor and environmental regulations, taxation - which impact the value of the business. ${ }^{49}$

Operational risk - the risk of loss resulting from failed or inadequate internal business processes, including systems, operational characteristics, and people. Operational risks also include external events and encompass a wide range of risks, including $^{50}$ :

- Quality risk - the risk that the product does not meet specifications outlined in the contract.

- Storage risk - the risk that the commodity cannot be stored appropriately, or at all.

- Legal risk - the potential losses from failure to comply with the law or adverse regulatory changes.

- Headline risk - the risk of negative publicity related to the activities, products or personnel of a company.

Operational risk is relatively big in the electricity market because of the low knowledge of risk management in combination with the complex contracts.

Basis risk - In the energy market, market movements may triggered by factors such as poor weather conditions, political developments, physical events or changes in regulation can lead to basis risk occurring in circumstances such as the following:

\footnotetext{
${ }^{48}$ Lewis, 2005, p.5.

${ }^{49}$ Unger, 2002, p.48

${ }^{50}$ Foundations of Energy Risk Management, 2009, p.13
} 
- Physical material in one location cannot be delivered to relieve a shortage in another location.

- A different quality of product cannot be substituted for an energy product in severe shortage. This often happens in the pipeline gas and power markets if there are any problems with transmission networks.

- There is not enough time to transport or produce an energy product to alleviate a shortage in the market. ${ }^{51}$

When conducting price risk management, the ideal derivatives contract is one that has a zero risk or the lowest basis risk with the energy price that protection is needed from. Consider an energy participant who believes he has a fully hedged position using futures contracts. Basis risk exists because it is possible that the value of the hedge may not move exactly in line with the value of the price exposure that the participant is trying to manage. Such situations occur when there is a breakdown of the expected or usual differential between two sets (or more) of prices. Basis risk occurs partly because financial instruments do not correlate perfectly to the underlying physical markets. There is no guarantee that the price of energy futures contracts will converge to the physical markets. Theoretically they should, but in practice they may not. ${ }^{52}$

Model Risk - Modeling is intended to help reduce risk by providing appropriate hedge calculations. Poor assumptions resulting in inadequate hedges can misstate market positions and actually increase risk exposure. Management must insist on adequate benchmarking to continually evaluate the appropriateness of all underlying models and assumptions. Model risk also lurks when a firm fails to employ consistent models and methodologies during valuation and portfolio analysis. A common inconsistency lies in the assumptions we make while pricing derivatives and assessing their risk.

\footnotetext{
${ }^{51}$ James, 2003, p.2

${ }^{52}$ Lewis, 2005, p.5
} 


\subsubsection{Energy Markets vs Money Markets}

Energy markets are young maturing markets continuing their transformation by the derivatives and risk management industry. In comparison, the money markets stand as mature markets with relatively few modeling mysteries left to conquer. Issues of storage, transport, weather, and technological advances play a major role in energy markets. The end user truly consumes the asset. Residential users need energy for heating in the winter and cooling in the summer, and industrial users' own production continually depends on energy to keep the plants running and to avoid the high costs of stopping and restarting them. Each of these energy market participants - be they producers or end users - deals with a different set of fundamental drivers, which in turn affect the behavior of energy markets. ${ }^{53}$

Table.1.1. Energy and money markets differences

\begin{tabular}{|c|c|c|}
\hline Issue & In Money Markets & In Energy Markets \\
\hline Maturity of market & Several decades & Relatively new \\
\hline Fundamental price drives & Few, simple & Many, complex \\
\hline Impact of economic cycles & High & Low \\
\hline Frequency of events & Low & High \\
\hline Impact of storage and delivery & None & Significant \\
\hline $\begin{array}{l}\text { Correlation between short and } \\
\text { long-term pricing }\end{array}$ & High & Lower, "split personality" \\
\hline Seasonality & None & $\begin{array}{c}\text { Key to natural gas and } \\
\text { electricity }\end{array}$ \\
\hline Regulation & Little & Varies from little to very high \\
\hline Market activity (liquidity) & High & Lower \\
\hline Market centralization & Centralized & Decentralized \\
\hline $\begin{array}{l}\text { Complexity of derivative } \\
\text { contracts }\end{array}$ & $\begin{array}{l}\text { Majority of contracts are } \\
\text { relatively simple }\end{array}$ & $\begin{array}{l}\text { Majority of contracts are } \\
\text { relatively complex }\end{array}$ \\
\hline
\end{tabular}

Source: Pilipovic, 2007, p.19 ${ }^{53}$ Pilipovich, Dragana; Valuing and Managing Energy Derivatives-Energy Risk, New York: McGraw-
Hill, 2007, p. 19-20 


\subsubsection{Risk Management in Energy Markets}

The energy industry traditionally has been prominent due to the high volatility of energy prices. During the last years this volatility reached unprecedented levels. Consolidation, liberalization, privatization, and crises in energy markets have made an increasing number of corporate leaders and regulators acknowledge the advantage of understanding and implementing active risk management policies. Risk management techniques applied in energy markets were originally developed in the traditional financial markets. However, being a physical asset, energy has traits of its own that are not accounted for by traditional valuation and risk management methodologies. The importance of such factors as transportation, storage, weather, technology, short-term demand and supply imbalances impose new dimensions on asset valuation that are not an issue for the purely financial assets.

Strong mean reversion and the presence of factors whose effect on the series depends on the maturity of an instrument are the main characteristics of energy price changes. There are also several demand and supply side factors that need to be incorporated in price change modeling, such as the convenience yield, seasonality relative illiquidity and high fragmentation of the market. When applied to the energy markets, general risk management practices should account for the following special risks: non-availability of market prices for certain periods, complex distributions, jumps, curve shifts, non-normality and outliers, limited liquidity, mean reversion, high and unstable volatility and correlations, nonstandard contracts, and high counterparty default risk. $^{54}$

Quantification of risk and its expression by a number is a tremendously important part of risk management. And for such applications an optimal measure of risk exposure is the Value at Risk (VAR). The use of value-at-risk (VAR) by financial institutions as a risk measure of their portfolios can be traced back to the 1980s. The popularity of VAR grew dramatically after J. P. Morgan introduced the RiskMetrics system in 1994 in an attempt to standardize risk measurement methodology.

\footnotetext{
${ }^{54}$ Khindanova, Irina ve Zauresh Atakhanova; 2002, "Stable Modeling in Energy Risk Management," Mathematical Methods of Operations Research, Vol. 55, Issue 2, p.226-227.
} 


\subsubsection{Value-at-Risk}

A value-at-risk model measures market risk by determining how much the value of a portfolio could decline over a given period of time with a given probability as a result of changes in market prices or rates. Value-at-risk models assume that the portfolio's composition does not change over the holding period. This assumption argues for the use of short holding periods because the composition of active trading portfolios is apt to change frequently. ${ }^{55}$

The definition of potential loss via VAR depends on its two main parameters horizon and degree of confidence. The horizon is the time period over which the potential loss is measured. The choice of the holding period depends on the liquidity of the assets in the portfolio and how frequently they are traded. The ideal holding period appropriate in any given market is the length of time it takes to ensure orderly liquidation of positions in that market ${ }^{56}$. The degree of confidence is a measure of the degree of certainty of the VAR estimate. The most common degree of confidence is $95 \%$, which means that $5 \%$ of the time, our portfolio will experience greater losses. ${ }^{57}$

The VAR is a perfect risk measure if forward price information is available and reliable. Implied volatility can be obtained from traded options, and correlations can be derived from market information. Otherwise, the VAR is only a guide. VAR concentrates on financial price risk. If the firm were a utility, the VAR analysis concentrates on the impact of electricity price changes in the value of the portfolio, but would ignore random fluctuation costs arising from credit, operational, legal, and other risks that the firm faces.

Because it is so simple, a VAR report does not include a lot of details. For example, it doesn't give any information about what will happen if the price of oil doubles or the stock market crashes. It also doesn't give any information about how bad

\footnotetext{
${ }^{55}$ Hendricks, Darryll; 1996, Evaluation of Value at Risk Models Using Historical Data, Economic Policy Review, Federal Reserve Bank of New York, Vol. 2 Issue.1, p.40

${ }^{56}$ Simons, Katerina; 1996, "Value at Risk-New Approaches to Risk Management," New England Economic Review, September:3-13, p.5

${ }^{57}$ Blanco, Carlos; 1998, "Value at Risk For Energy: Is VaR Useful to Manage Energy Price Risk?,"

Financial Engineering, December:1-7, p.2
} 
things could get in the event of a really bad loss. VAR also gives the minimum threshold for a move that can be expected with some frequency. For example, if the model determines a daily profit or loss of at least $\$ 1$ million is expected once a month, the report did not give a lot of insight into whether the move is likely to be $\$ 1$ million, $\$ 2$ million, or $\$ 10$ million $^{58}$. The results of VAR analysis ultimately give management a sense of what could happen over a period of time with certain probability measures attached to the various scenarios.

There are four mainstream methods of calculating VAR: the variancecovariance (delta) method, Monte-Carlo simulations, historical simulations and stress testing.

\subsection{The Variance-Covariance Model}

The most commonly used of the VAR methods is based on the analysis of the volatilities and correlation between the different risk exposures of the firm's portfolio. The variance-covariance method of portfolio risk estimation is based on the linear approximation of relative price changes and the assumption that asset returns are normally distributed. The VaR is estimated on the basis of the variance-covariance matrix and the delta, which is the measure of the sensitivity of an asset price to the underlying risk factors. ${ }^{59}$ This method is very applicable to energy markets, particularly when performed simultaneously and in comparison with Monte Carlo simulation.

Analytical model has its advantages in application. It is simple if only the second moment calculated. It is quite reliable for small horizons. It involves quick calculation. But he model can be complicated if higher moments (skew and kurtosis) are calculated and can be unreliable if the time period is longer than a month. ${ }^{60}$ The choice of vertices or risk factors in this model will depend on the availability of historical data, and the user's needs regarding the level of detail and precision in the analysis. For example, an airline may have to use WTI or Heating Oil as the risk factor for Jet Fuel

\footnotetext{
${ }^{58}$ Edwards, 2009, p.347

${ }^{59}$ Khindanova, 2002, p.227

${ }^{60}$ Pilipovich, Dragana; Valuing and Managing Energy Derivatives-Energy Risk, New York: McGrawHill, 2007, p.422
} 
risk, due to the lack of exchange traded contracts in Jet Fuel. In the choice of Jet Fuel, the airline may be interested in breaking the risk depending on the different delivery points, maturities of the contracts, etc. In most circumstances, the more risk factors or vertices used, the more data required, but the more information given about the risk of the positions. ${ }^{61}$

\subsection{Monte Carlo Simulations}

Although computation time is getting faster and faster, the problem of using Monte Carlo simulations for valuing contracts on a fast paced trading floor remains a practical concern, both in terms of processing time as well as in ensuring a marked-tomarket compliance. Although these simulations may not be appropriate for a trading floor, they are most certainly a great tool for testing methodologies being considered for the trading floor. For valuing assets where the valuation is already filled with longreaching assumptions potentially covering several decades, and where the valuation processing time is not an important factor, Monte Carlo simulations provide an excellent way of getting an idea about ranges of reasonable values given multiple scenarios and a multitude of possible factors.

Monte Carlo simulations represent a good VAR methodology that could be used throughout the markets. The degree of application difficulty of the model varies with the number of variables simulated. Hence, simulations are simple if variables are kept to a minimum. It provides full P\&L distribution, including skew and kurtosis effects. The model can simulate lots of variables, including volatilities. Monte Carlo tools are available on most software (for example, spreadsheets). The model's main disadvantage is its complexity. Complexity grows with the number of factors simulated. It does not maintain certain intuition about the forward price curve when a multifactor approach is taken. The model does not capture the full scope of market risk when only a single factor or two factors are simulated. These simulations may take a long time to run. $^{62}$

\footnotetext{
${ }^{61}$ Blanco, 1998, p.4

${ }^{62}$ Pilipovich, 2007, p.421
} 
Monte Carlo simulations are not limited by the number of entries in the historical time series and can generate an arbitrarily large set of risk factors. This feature of the method is useful from the accuracy point of view. In the case of energy applications we mostly see Monte Carlo simulations and analytical variance-covariance (analytical) models as competitors in the implementation of the VAR methodology. ${ }^{63}$

\subsection{Historical simulation}

Historical simulation consists of revaluing the portfolio for several hundred historical scenarios and build a "hypothetical" distribution of profit and losses based on how the portfolio would have behave in the past. Historical simulations has the advantage that does not use estimated variances and covariances, and we do not make any assumptions about the distribution of the portfolio returns. However, we are assuming that the past risk reflects the future risk, which in energy markets is a very extreme assumption. If we think that "every day is a new day in the energy markets", historical simulation is definitely not the method to use to capture risk. ${ }^{64}$ To calculate VAR through historical simulation we need a database with historical prices for all the risk factors that we want to include in the simulation, and pricing models to reevaluate the portfolio for each price scenario. In the case of electricity markets or OTC energy markets, it is especially difficult to calculate the historical simulation VAR due to the lack of easily available and transparent historical data.

Historical simulations have some drawbacks in application. Historicals take us "backward," not forward. Current market-implied information about the future is not included in this model. The results of the past are already known, thus it represents a single "path." Going forward is different, here many paths are possible.

\subsection{Stress Tests}

The purpose of stress testing is to identify the exposure to exceptional market events by imposing scenarios on a position, judgment about the likelihood of such events and estimation of their impact on the portfolio value. Stress testing ignores the

\footnotetext{
${ }^{63}$ Eydeland, 2003, p.446

${ }^{64}$ Blanco, 1998, p.6
} 
correlations between the market variables and is not based on objective probabilities of extreme events occurring. Stress testing is particularly valuable in electricity markets, which are subject to enormous price changes due to the regional nature of the market, lack of storage and susceptibility to the weather risk. ${ }^{65}$

Historical scenarios in stress testing employ shocks that occurred in specific historical episodes. A simple way to do this is to identify days in the past that were "stressful" and use the observed changes in market risk factors on those days. For example, a portfolio of market risk exposures could be stress tested by seeing how its value would change given the changes recorded for market risk factors for a day, or over a longer period. The selection of the day, or period, is typically based on "headline" disturbances ${ }^{66}$, such as the Gulf War in the oil markets, Iraq invading Kuwait, big OPEC decisions, or the power crisis in California.

One advantage of this technique is that the structure of market factor changes is historical rather than arbitrary. Another advantage of historical scenarios is their transparency. A statement like "if the Gulf War happened tomorrow, the firm would lose X million dollars" is easy to understand and put in to perspective. This model is good for doing deltas numerically if one cannot generate them theoretically. ${ }^{67}$

Hypothetical scenarios use a structure of shocks thought to be plausible in some foreseeable circumstances for which there is no exact parallel in recent history. This begs the question how far back in history do you go. Generally many energy traders do not look back beyond more than five years of historical data. This is because the further one looks back in history, the bigger the chances are that the fundamental supply/demand factors of the energy market will have changed.

\subsubsection{Common Risk Management Tools}

When investors, managers, or a firm's owners are averse to risk, there is an incentive to take actions to reduce it. There are several different risk management tools

\footnotetext{
${ }^{65}$ Khindanova, 2002, p.228

66 James, 2002, p.139

${ }^{67}$ Pilipovic, 2007, p.420
} 
available for companies. Primarily, energy companies use the following approaches like insurance, diversification or long-term fixed contracts to manage their risks.

Diversification - investing in a variety of unrelated businesses, often in different locations - can be an effective way of reducing a firm's dependence on the performance of a particular industry or project. In theory it is possible to "diversify away" all the risks of a particular project. In practice, however, diversification is expensive and often fails because of the complexity of managing diverse businesses. More fundamentally, the success of most projects is strongly tied to the state of the general economy, so that the fortunes of various businesses and projects are not independent but move together. ${ }^{6}$

Insurance contracts - All businesses use insurance contracts to manage risk. For example, to reduce the financial impact of an explosion at an LNG project, the project's owner could acquire insurance to compensate for lost revenue as well as the cost of having to secure other gas supplies. Insurance also shifts the risk to the insurance provider, who in exchange for the insurance premium is willing to compensate the purchaser of the insurance contract for a loss in the project. The counterparty would accept the risk if it had greater ability to pool risks and were less averse to risk than was the owner of the project.

Long-term fixed contracts - Many businesses reduce market risk by entering into long-term fixed price contracts. For example, the developer of a LNG project signs a long-term contract with a gas consumer up to 20 years and "lock in" the gas price that makes the development of the project economically viable. Even when the market price of the gas drops below the contractual price, the gas is still sold at the contract price, which benefits the developer of the project. When the market price of the gas is higher than the price specified in the contract, the benefit accrues to the consumer. The two parties to the contract share the risks of price changes and are willing to give up potential gains to compensate for potential losses. ${ }^{69}$

\footnotetext{
${ }^{68}$ Hale, 2002, p.3

${ }^{69}$ Foundations of Energy Risk Management, 2009, p.23
} 


\section{DERIVATIVE MARKETS}

\section{AND ENERGY DERIVATIVE INSTRUMENTS}

Although derivatives have been used in the World since the mid-1800s and are a mainstay of international currency and interest rate markets, their use in domestic energy industries has come about only in the past 20 years with energy price deregulation. Under regulation, domestic petroleum, natural gas, and electricity prices were set by regulators and infrequently changed. Deregulation revealed that energy prices are among the most volatile of all commodities. Widely varying prices encouraged consumers to find ways to protect their budgets, producers looked for ways to stabilize cash flow. Derivative contracts transfer risk, especially price risk, to those who are able and willing to bear it. When used prudently, derivatives are efficient and effective tools for isolating financial risk and "hedging" to reduce exposure to risk.

\subsection{DERIVATIVE INSTRUMENTS}

Derivatives are contracts, financial instruments, which derive their value from that of an underlying asset. Unlike a stock or securitized asset, a derivative contract does not represent an ownership right in the underlying asset.

The energy derivatives markets provide risk managers and traders with an enormous choice of instruments both for price risk management and for speculation. Derivatives are extending market depth with increasing liquidity in those markets. They provide alternative opportunities in the management of market and default risks. The major financial instruments applied in derivative markets are set into four groups forwards, futures, options and swaps.

Forward contracts. A forward agreement is an agreement made between two counterparties to sell or buy an underlying item at a certain future time for a certain price. The price agreed is referred to as the delivery price. Forwards are bilateral contracts whose terms can be decided by the parties involved. As OTC contracts, forwards may provide a more exact match of the needs of the parties involved than is possible with a standardised exchange-traded product, but with this flexibility comes 
potentially greater counterparty risk because of the lack of a clearing house arrangement. ${ }^{70}$ Forwards may be related to interest rates, bond prices, foreign currency, a basket of equities, a commodity or more recently, credit risk. These contracts involve no "upfront" payment and "cash" changes hands only at the expiry of the contract. ${ }^{71}$

Futures contracts. Futures are exchange traded forwards and consequently are traded in a standardised format, traded in predetermined bundles for settlement only on certain fixed dates and settled through a clearing house. Some traders use the futures market as a proxy for the market in the underlying asset. Futures are marketable, which means that contracts can be closed out by selling the contract prior to maturity. In contrast to forward contracts, futures contracts are marketable and involve a down payment known as the "initial margin". 72

Options Contracts. An options contract confers on the holder the right, but not the obligation, to conduct a transaction on or by a future date at a pre-determined price. Options can be either exchange traded or OTC. Options may be either puts or calls. A put gives the holder of the option the right to sell the underlying item at the specified price, and a call gives him the right to buy the item. Call options on some assets - equities and commodities - have, in theory, unlimited potential for notional profit, as there is no limit to price increases, although there is of course an expected maximum likely profit. ${ }^{73}$

Swaps. A swap is an agreement between two parties to exchange cash flows in the future. The agreement defines the dates when the cash flows are to be paid and the way in which they are to be calculated. Usually the calculation of the cash flows involves the future values of one or more market variables. A forward contract can be viewed as a simple example of a swap. Whereas a forward contract leads to the exchange of cash flows on just one future date, swaps typically lead to cash flow

\footnotetext{
${ }^{70}$ Gray, Simon and Place, Joanna; Financial Derivatives, Centre for Central Banking Studies, Bank of England, 1999, p.12-16

${ }_{71}$ Cuthbertson, Keith and Nitzsche, Dirk, Futures and Forwards, PRMIA I.B.3., p.2

${ }^{72}$ IBIT, p. 3

${ }^{73}$ Gray, 1999, p. $27-28$
} 
exchanges taking place on several future dates. ${ }^{74}$ A "Swap" can be related to interest rates, foreign exchange rates, equities, commodities and credit risk.

\subsection{USAGE OF THE DERIVATIVES}

In commodity markets the derivative instruments generally are used for hedging, speculation and arbitraging purposes.

\subsubsection{Hedging}

The objective of hedging is to reduce market or price risk and attempt to control the effects of adverse price movements. Sophisticated financial instruments focus on reducing the price risk. But even so, not all the price risk is reduced because basis risk still exists.

Hedging does not affect volume, quality, or legal risks. These operational risks are significant in the management of an energy company. Moreover, there might not be appropriate hedging products available, and those that are available, either on the OTC markets or exchanges, may not fully cover the risks. Operational risks represent a natural example of residual risks. ${ }^{75}$ Even with such shortcomings, companies should hedge. Hedging reduces to a certain degree, the uncertainty surrounding future events. Just reducing one of the many risks a company faces allows its management to focus on other aspects of running and building the business, as well as mitigating other risks.

An example of how to use a futures contract to avoid unpleasant gas-price surprises is given in Table2.1. On July 23, we project our winter natural gas consumption volume requirements for January to be $10,000 \mathrm{MMBTU}$ and purchase a January futures contract to giving us the right to purchase that amount of gas at $\$ 3.00$. Our motivation is to protect against an increase in prices, and we are willing to take the chance that the price might be below that option price in January. The current gas price for immediate delivery may be lower or higher than $\$ 3.00$ at the time we buy the futures contract. That is immaterial because we aren't buying the gas then. At that time we are only contracting to buy the gas for

\footnotetext{
${ }^{74}$ Hull, 2003, p. 135

${ }^{75}$ Foundations of Energy Risk Management, 2009, p. 83-85
} 
delivery in January. The last day of trading before the option expires on December 27 we can sell out the futures position and simultaneously purchase the needed gas in the physical market. Here we assume two possible scenarios: a settlement at a January price of $\$ 6.00$, or a settlement at a January price of $\$ 2.00$. Note that, in this example, we'll pay $\$ 3.00$ for the gas independent of the market price on the expiration date. ${ }^{76}$

Table 2.1. Hedging natural gas price risk with futures contract

\begin{tabular}{|c|c|c|c|c|c|c|c|c|c|}
\hline \multicolumn{5}{|c|}{ Settlement Price at $\$ 6$} & \multicolumn{5}{|c|}{ Settlement Price at $\$ 2$} \\
\hline \multirow{2}{*}{ Date } & \multicolumn{2}{|c|}{$\begin{array}{l}\text { Financial } \\
\text { Transaction }\end{array}$} & \multicolumn{2}{|c|}{$\begin{array}{l}\text { Physical } \\
\text { Transaction }\end{array}$} & \multirow{2}{*}{ Date } & \multicolumn{2}{|c|}{$\begin{array}{l}\text { Financial } \\
\text { Transaction }\end{array}$} & \multicolumn{2}{|c|}{$\begin{array}{l}\text { Physical } \\
\text { Transaction }\end{array}$} \\
\hline & Buy & Sell & Buy & Sell & & Buy & Sell & Buy & Sell \\
\hline July 23 & $\begin{array}{c}\text { Jan. fut. } \\
\$ 3\end{array}$ & & & & July 23 & $\begin{array}{c}\text { Jan. fut. } \\
\$ 3\end{array}$ & & & \\
\hline Dec. 27 & & $\begin{array}{c}\text { Jan. fut. } \\
\$ 3\end{array}$ & $\begin{array}{c}\text { Jan. phy. } \\
\$ 6\end{array}$ & & Dec.27 & & $\begin{array}{c}\text { Jan. fut. } \\
\$ 2\end{array}$ & $\begin{array}{c}\text { Jan. phy. } \\
\$ 2\end{array}$ & \\
\hline Result & & $\begin{array}{c}\$ 3 \\
\text { Profit }\end{array}$ & $\begin{array}{c}\$ 6 \\
\text { Purchase }\end{array}$ & & Result & & $\$ 1$ Loss & $\begin{array}{c}\$ 2 \\
\text { Purchase }\end{array}$ & \\
\hline
\end{tabular}

\subsubsection{Speculation}

Speculation is a high risk activity that is usually outside the industrial end user's core business. ${ }^{77}$ Speculative trading seeks to simply capture price changes or price differentials for a commodity. Speculators are not hedging against an underlying commodity position. They are just buying and selling contracts hoping to make a profit. For example, a speculator would purchase crude oil in anticipation of the price of the oil increasing. The speculator takes the risk of the price of oil not increasing, but actually decreasing.

\footnotetext{
${ }^{76}$ Hedging Your Energy Cost Bets, Gas Technology, 2003, p. A12

${ }^{77}$ Gas Technology, 2003, p. A11
} 
There are different types of speculators. Scalpers have a very short time horizon and are seeking small differences in the bid-ask prices of the commodities being traded. Scalpers may take large positions for a very short period of time, often only minutes, in commodities and hope that the price of the commodity would move in their direction. Day traders are similar to scalpers, but their time horizon is longer. They may assume large positions in the commodity, but they are generally willing to hold the commodity for a day or longer, perhaps just overnight. Position traders take positions in the commodities or in a combination of commodities, and hold their positions for a long time. Sometimes they combine long and short positions with different expiration dates across different markets and even across different energy products to capture differences in prices and to make a profit. Through their frequent trading, both scalpers and day traders are said to add liquidity to the market. ${ }^{78}$

\subsubsection{Arbitrage}

There are a number of different definitions for arbitrage. The theory behind pure or risk-free arbitrage is simple. A trader buys a barrel of oil in Rotterdam for USD 45 and then simultaneously sells the very same barrel of oil in Midland, Texas, for USD 46, making an arbitrage profit of USD 1. Since both transactions take place at the same time, there is no need for any financial commitment or investment in the transaction, thus, it would make people enormously wealthy. However, such arbitrage cannot exist.

There are several other reasons why there is no arbitrage without risk. Through competition between the buyers and the sellers, the price differential between the two markets would disappear. Even if the oil is bought in Rotterdam and sold simultaneously in Midland, there are expenses associated with storing and transporting the oil between these two geographical locations. And even if the price differential between these places would cover the actual cost of storage and transportation, there has to be an investment.

\footnotetext{
${ }^{78}$ Foundations of Energy Risk Management, 2009, p.82
} 


\subsection{TYPES OF DERIVATIVES MARKETS}

Derivative instruments are either traded on Organized Exchanges or settled on Over-the Counter markets.

\subsubsection{Organized Energy Exchange Markets}

An energy derivatives exchange is a market where individuals trade standardized contracts that have been defined by the exchange. On-exchange refers to the futures and options markets which are found on regulated financial exchanges such as New York Mercantile Exchange (NYMEX), London's International Petroleum Exchange (IPE) or Tokyo Commodity Exchange (TOCOM) and so on, all over the world. $^{79}$

Traditionally derivatives traders have met on the floor of an exchange and used shouting and a complicated set of hand signals to indicate the trades they would like to carry out. This is known as the open outcry system. In recent years exchanges have increasingly moved from the open outcry system to electronic trading. The latter involves traders entering their desired trades at a keyboard and a computer being used to match buyers and sellers. ${ }^{80}$

\subsubsection{Over-the-Counter Energy Markets}

The OTC market is specific to the nonstandard swaps and OTC options. These are usually traded directly between two principals in the energy markets. The OTC energy market is not nearly as price transparent as, for example, the OTC foreign exchange market. Despite this, corporate end-users and producers tend to prefer the OTC markets since basis issues are fewer and products can be structured to more closely replicate their cash market activities. ${ }^{81}$

\footnotetext{
${ }^{79}$ James, 2003, p.9

${ }^{80}$ Hull, 2003, p.2

${ }^{81}$ McCann, Karen and Nordström, Mary; Energy Derivatives: Crude Oil and Natural Gas, Federal Reserve Bank Of Chicago, 1995, p.3
} 
The effectiveness of the OTC market can also be seen in Asia, which overtook Europe as the second largest oil consuming region in the world several years ago. Today, Asia includes the world's second, third, seventh, eighth and ninth largest importers of oil: Japan, Korea, India, China and Taiwan. However, Asia still does not have a liquid and internationally recognised futures exchange for energy market. This is because its needs for energy-related derivatives contracts seem to be well served by the established OTC market, for which Singapore is the key trading hub. The main OTC trading/pricing hubs for Europe are Mediterranean, Arab Gulf, North West Europe (N.W.E.) and Amsterdam-Rotterdam-Antwerp (A.R.A.). New York Harbor, US Gulf Coast, US West Coast (L.A. Pipeline) are some international reference points for oil markets in USA. ${ }^{82}$

OTC oil trading is a market that is monitored but not regulated by government agencies. However, with the increasing level of convergence between OTC and futures, as seen in the clearing house initiatives to permit OTC derivatives to be cleared via existing futures clearing houses such as NYMEX or the London Clearing House, the core OTC energy derivatives are becoming more and more indistinguishable from futures trades. ${ }^{83}$

\subsection{ENERGY DERIVATIVES}

Energy derivative instruments include futures and options contracts traded on standardized exchanges and forward, swap, unstandardised options contracts traded on OTC exchanges.

\subsubsection{Energy Forwards}

Energy forward contracts are over-the-counter products. They don't need to be standardized and they can be structured in the way which is most convenient to the counterparties. This flexibility is one of the reasons why electricity forward contracts

\footnotetext{
${ }^{82}$ James, 2003, p.72-74

${ }^{83}$ IBIT, p.75
} 
are currently more popular than futures. Forward contracts almost invariably involve the delivery of the underlying asset. ${ }^{84}$

Forward contracts obligate its owner to buy a given asset on a specified date at a forward price specified at the origination of the contract. If, at maturity, the actual price is higher than the exercise price, the contract owner makes a profit, if the price is lower, the owner suffers a loss. The default (or credit) risk of the contract is two-sided. The value of the forward contract is conveyed only at the contract's maturity, no payment is made either at origination or during the term of the contract. ${ }^{85} \mathrm{~A}$ forward contract may also be used as a speculative instrument, where the buyer or seller anticipates future price movements and hopes to gain from them, or as an arbitrage against other markets where an opportunity exists. ${ }^{86}$

A usual energy forward contract must specify such characteristics as delivery details, delivery price or formula for computing delivery price, delivery period and time of delivery during this period, and delivery location (Table 2.2.).

Table 2.2. Example of a Fixed-price Forward Contract for a Power Delivery

\begin{tabular}{|l|l|l|l|}
\hline Buyer & ABC & Seller & XYZ \\
\hline Quantity (MW) & 50 & Quantity & 16,800 \\
\hline Price (\$MWh) & 40.50 & Type of energy & Firm (LD) \\
\hline Start Date & April 1, 2009 & End Date & April 30, 2009 \\
\hline Day of Week & $\begin{array}{l}\text { Monday-Friday, } \\
\text { Excluding Peak } \\
\text { hours } \\
\text { Holidays }\end{array}$ & Hours & $07: 00-22: 00$ \\
\hline Delivery Point & Seller's choice into Cinergy interface & \\
\hline
\end{tabular}

Source: Eydeland and Wolyniec, 2003, p.31

Forward contracts, unlike futures, are not settled daily. On the positive side, this means that a contract holder does not have to worry about having daily access to

\footnotetext{
${ }^{84}$ Cuthbertson and Nitzsche, 2004, p.3

${ }^{85}$ Smithson, Charles W.; Managing Financial Risk, Third edition, New York: McGraw-Hill. 1998, p. $29-30$

${ }^{86}$ Gray, 1999, p.16
} 
cash to satisfy margin requirements. On the negative side, if the market moves in the right direction, for instance, the contract ends up being in-the-money, the contract holder becomes exposed to counterparty credit risk. ${ }^{87}$

Forward markets are markets in which the parties contract for the delivery of energy in the future. The forward markets take on two forms ${ }^{88}$ :

Bilateral or Broker-based (OTC). The trading involves either direct contact between two parties or contact mediated by a broker (possibly an electronic broker like InterContinental Exchange Trade or Spark).

Market Maker-based. The trading is centered around a market maker who posts two-sided (for buying and selling) quotes, stands behind every transaction, and can carry inventory. Examples include the once omnipresent EnronOnLine, DynegyDirect or UBSWEnergy.com.

\subsubsection{The Value of Energy Forward Contract}

The value of a fixed-price forward contract for future delivery of a unit of commodity is being estimated by this formula ${ }^{89}$ :

$$
V_{f}\left(t, F_{t, T}\right)=N \cdot e^{-r\left(t, T_{p a y}\right)\left(T_{p a y}-t\right)} \cdot\left(F_{t, T}-X\right)
$$

In this formula:

$t$ - time at which the contract is evaluated

$X-$ a contractual fixed price to be paid for one unit of the delivered commodity

$T_{\text {pay }}$ - the payment time (it can be different from the contract settlement time)

$r\left(t, T_{p a y}\right)$ - an annualized, continuously compounded discount rate from $t$ to $T_{p a y}$

$e^{-r\left(t, T_{p a y}\right)\left(T_{p a y}-t\right)}-$ correspondent discount factor

$N$ is the number of commodity units to be delivered under the contract

\footnotetext{
${ }^{87}$ Eydeland and Wolyniec, 2003, p.32

${ }^{88}$ IBIT, p. 8

${ }^{89}$ IBIT, p.33
} 
$F_{t, T-}$ is the price at time $t$ of the futures contract settled at the same time as the forward contract

$V_{f}\left(t, F_{t, T}\right)$ - the value of a fixed-price forward contract at time $t$

\subsubsection{Energy Futures Contracts}

An energy futures contract is a standardised agreement between two parties that commits one party to sell and the other party to buy a stipulated quantity and grade of oil, gas, power, coal, or other specified item at a set price on or before a given date in the future. Futures contract requires the daily settlement of all gains and losses as long as the contract remains open. The expiry of the contract provides either delivery of the underlying physical energy product or a final cash payment. ${ }^{90}$

Energy futures contracts stipulate that the buyer of the commodity has a long position and the seller has a short position. The contract date is designated by the delivery month. The exact delivery date is specified by the rules of a standard contract and varies by product. For example, NYMEX oil futures stop trading three business days prior to the 25 th of the month. On the 25 th of the month, pipeline nominations are made for the next month. Nominations are the schedules for shipment for the next month. The spot and one-month futures price are almost synonymous, and the onemonth futures is often used as a quote for the spot price or is designated as the spot price in contracts. ${ }^{91}$

Energy futures contracts are highly standardized liquid financial instruments. The futures markets help businesses manage their price risk by providing a means of hedging matching buyers and sellers of a commodity with parties who are either more able or willing to bear market risk, or who have inverse risk profiles. Because futures are traded on exchanges that are anonymous public auctions with prices displayed for all to see, the markets perform the important function of price discovery. The diverse views of many market participants are distilled to a single price. ${ }^{92}$

\footnotetext{
${ }^{90}$ James, Tom; Energy Price Risk, New York: Palgrave Macmillan. 2003, p.33

${ }^{91}$ Dahl, 2004, p.373

92 Energy Complex; What do futures do for the energy markets?, Energy Media Group, 2006, p.3
} 
Table 2.3. Energy Futures Contracts Trading More Than 100,000 Contracts per Year

\begin{tabular}{|l|l|l|}
\hline Contract & Market & Delivery Point \\
\hline Crude Oil & New York & Cushing, Oklahoma \\
\hline Natural Gas & New York & Henry Hub, Louisiana \\
\hline Brent Crude Oil & London & EFP/Cash Settlement \\
\hline No.2 Heating Oil & New York & New York Harbor \\
\hline Unleaded Regular Gasoline & New York & New York Harbor \\
\hline Gasoil & London & A.R.A. Area \\
\hline Natural Gas & London & UK NPB \\
\hline Source: Erreran
\end{tabular}

Source: Errera and Brown, 2002, p.3

Today there are more than sixty marketplaces worldwide where trading in futures contracts occurs. Energy futures contracts are enhancing the operation of the primary energy sources distribution system and changing the way these energy commodities are priced worldwide. Even though energy futures stipulate physical delivery, such action usually represent only a minuscule share of the trading volume - less than $1 \%$ for energy - overall. ${ }^{93}$

\subsubsection{Counterparties in Energy Futures Contracts}

There are two parties to every contract - one party agrees to buy and take delivery in the future and the other party agrees to sell and make delivery in the future. The party that agrees to buy and take delivery has as a long position. The general notion of a long position is that profits are made when prices increase and losses occur when prices decrease. With a short position profits occur when prices decrease and losses occur when prices increase. The profit or loss on a short position is thus opposite to the profit or loss on a long position.

\footnotetext{
${ }^{93}$ Errera, Steven and Brown, Stewart L.; Fundemantals of Trading Energy Futures\&Options, Second Edition, Oklahoma: Pennwell. 2002, p.1-2
} 
For instance, assume a trader buys a heating oil contract that calls for the delivery of 42,000 gallons of heating oil. The price of the contract is $\$ 1$ per gallon. The total value of his position is $\$ 1 \times 42,000$ gallons, or $\$ 42,000$. If the price of the futures contract should increase to $\$ 1,015$ per gallon, the contract would be worth $\$ 1,015 \times 42,000$, or $\$ 42,630$. The price has increased and the buyer has profited by $\$ 630$ which is the $\$ .015$ per gallon increase multiplied by 42,000 gallons. If the price of the contract had decreased to $\$ 0.995$, the total value of the contract would be $\$ 41.790$ and the buyer of the contract would have lost $\$ 210$. The profits and losses resulting from selling a contract (short position) are opposite those of the long position.

Because there is a long contract outstanding for every short contract, it is always so that for every winner in the commodity futures market there is also a loser. Gains and losses in the market always net out and the exchange itself is unaffected when prices increase or decrease. Thus, commodity futures contracts are what is called a zero-sum game. $^{94}$

\subsubsection{Margin Requirements and Clearinghouse's role in Energy}

\section{Futures Contracts}

At the time the contract was purchased, no actual money changed hands between the makers of the contract. All financial dealings with the commodity exchanges are through their clearinghouses. Exchanges require that buyers and sellers of contracts deposit and maintain funds as a guarantee of performance on the contract. This is called margin.

There are two types of margin on futures contracts: initial margin and maintenance margin. Initial margin requirements are fixed dollar amounts, which are typically between $5 \%$ and $10 \%$ of the value of the commodity under contract. Initial margin requirements are determined by the exchange and are updated periodically when factors such as price volatility and contract value change. Initial margins serve as a good-faith deposit for the execution of the contract. ${ }^{95}$ The maintenance margins, also known as

\footnotetext{
${ }^{94}$ Errera and Brown, 2002, p.11-12

95 IBIT, p.13-14
} 
variation margins, are typically between 60 and $85 \%$ of the initial margin. The concept of maintenance margin is that when a contract suffers losses to the point that margin has decreased to 60 to $85 \%$ of initial margin, the trader will receive a margin call and be required to deposit additional margin money to bring the account equity up to the initial margin requirement. Should the customer fail to deposit the additional money, the brokerage firm will liquidate the position. ${ }^{96}$

Financial institutions that provide clearing and settlement services for financial transactions in futures exchanges are clearing houses. A clearing house exists primarily to reduce the risks of settlement failures. Typically, a clearing house will provide services such as netting, central counter-party and exposure management in order to control counter-party risk.

The daily revaluation of a derivatives portfolio is referred to as "marking-tomarket". The norm in the energy trading world is to mark-to-market derivatives every day for risk management and general management reporting and control purposes. ${ }^{97}$ If your futures contract increases in value during the trading day, this gain is added to your margin account at the day's end. Conversely, if your contract loses value, this loss is deducted. And if your margin account balance falls below some agreed-upon minimum, you are required to post additional funds. ${ }^{98}$

Table 2.4 illustrates how futures contracts can be used both to fix a price in advance and to guarantee performance. Suppose in January a refiner can make a sure profit by acquiring 10,000 barrels of WTI crude oil in December at the current December futures price of $\$ 28$ per barrel. One way he could guarantee the December price would be to "buy" 10 WTI December contracts. The refiner pays nothing for the futures contracts but has to make a good-faith deposit ("initial margin") with his broker. NYMEX currently requires an initial margin of $\$ 2,200$ per contract.

\footnotetext{
${ }^{96}$ Errera and Brown, 2002, p.14

${ }^{97}$ James, 2003, p.29

${ }^{98}$ Smithson, 1998, p. 30
} 
Table 2.4. Example of an Oil Futures Contract

\begin{tabular}{|c|c|c|c|c|}
\hline \multirow[b]{2}{*}{ Date } & \multicolumn{2}{|c|}{ Prices per Barrel } & \multirow[b]{2}{*}{ Contract Activity } & \multirow[b]{2}{*}{ Cash In (Out) } \\
\hline & $\begin{array}{l}\text { WTI } \\
\text { Spot }\end{array}$ & $\begin{array}{l}\text { December } \\
\text { Future }\end{array}$ & & \\
\hline January & $\$ 26$ & $\$ 28$ & $\begin{array}{l}\text { Refiner "buys" } 10 \text { contracts for } 1,000 \\
\text { barrels each and pays the initial margin }\end{array}$ & $(\$ 22,000)$ \\
\hline May & $\$ 20$ & $\$ 26$ & Mark to market: $(26-28) \times 10,000$ & $(\$ 20,000)$ \\
\hline September & $\$ 20$ & $\$ 29$ & Mark to market: (29-26) x 10,000 & $\$ 30,000$ \\
\hline October & $\$ 27$ & $\$ 35$ & Mark to market: $(35-29) \times 10,000$ & $\$ 60,000$ \\
\hline $\begin{array}{l}\text { November } \\
\text { (end) }\end{array}$ & $\$ 35$ & $\$ 35$ & $\begin{array}{l}\text { Refiner either: } \\
\text { (a) buys oil, or } \\
\text { (b) "sells" the contracts . } \\
\text { Initial margin is refunded }\end{array}$ & $\$ 22,000$ \\
\hline
\end{tabular}

Source: Hale, 2002, p.9

During the year the December futures price will change in response to new information about the demand and supply of crude oil. In the example, the December price remains constant until May, when it falls to \$26 per barrel. At that point the exchange pays those who sold December futures contracts and collects from those who bought them. The money comes from the margin accounts of the refiner and other buyers. The broker then issues a "margin call," requiring the refiner to restore his margin account by adding $\$ 20,000$ to it. Following settlement after the first change in the December futures price, the process is started anew, but with the current price of the December future used as the basis for calculating gains and losses. In September, the December futures price increases to $\$ 29$ per barrel, the refiner's contract is marked to market, and he receives $\$ 30,000$ from the exchange. In October, the price increases again to $\$ 35$ per barrel, and the refiner receives an additional $\$ 60,000$. By the end of November, the WTI spot price and the December futures price are necessarily the same. The refiner can either demand delivery and buy the oil at the spot price or "sell" his contract. In either event his initial margin is refunded, sometimes with interest. If he buys oil he pays $\$ 35$ per barrel or $\$ 350,000$, but his trading profit is $\$ 70,000(\$ 30,000+$ $\$ 60,000$ - \$20,000. Effectively, he ends up paying $\$ 28$ per barrel [ $\$ 350,000$ - 
\$70,000)/10,000], which is precisely the January price for December futures. If he "sells" his contract he keeps the trading profit of $\$ 70,000.99$

\subsubsection{Energy Options Contracts}

An energy option is a standardized contract that gives the option holder the right, but not the obligation, to purchase or sell a certain energy commodity at a predetermined strike price. The option seller has the obligation to deliver or purchase the commodity upon exercise by the option holder. ${ }^{100}$

Option market participants either want to protect themselves from price risk or simply take advantages of price movements by speculation. There are two basic types of options traded in futures markets - call options and putt options. As we have seen, the owner of a forward and futures contracts has an obligation to perform, while an option gives its owner a right, not an obligation. ${ }^{101}$

\subsubsection{Options Premium}

The option premium is the price the buyer of the options contract pays for the right to buy or sell a commodity at a specified strike price in the future. It is calculated by the following formula:

Option Premium = Intrinsic Value + Time Value Premium

Here an "intrinsic value" is equal to the difference between the "strike price" and the "current market rate".

Volatility plays an important part in the pricing of an option strategy and is also an important part of evaluating whether or not an option should be considered too expensive to purchase or not. There are two types of volatility. First, historical volatility, which is a normalised annualised standard deviation of the underlying energy futures contract. Second, implied volatility, the volatility value placed on an option

\footnotetext{
${ }^{99}$ Hale, 2002, p.9-10

${ }^{100}$ Burger, 2007, p.53

${ }^{101}$ Smithson, 1998, p.34
} 
premium quotation from a trader or market maker. ${ }^{102}$ Implied volatility, can be very different from the historical volatility. The historical volatility uses historical price data in its calculation, thus it is a volatility measure of already-past price behavior. The market-implied option volatility, on the other hand, represents what the market expects the option underlying price uncertainty to be over the time period from today until the option expiration date. Market-implied volatility "looks" forward in time, and as such is a reflection on how volatile the market believes the prices will be over the time period till the option's expiration. In most cases, the higher the implied volatility, the higher the premium of the option. ${ }^{103}$

\subsubsection{Call Option}

A call option gives the buyer the right, but not the obligation, to enter into a long futures position at a predetermined strike price, and obligates the seller to enter into a short futures position at that price, should the option be exercised.

Consider the situation of an investor who buys a European call option with a strike price of $\$ 80$ to purchase 1000 barrels of oil. Suppose that the current oil price is $\$ 78 /$ barrel, the expiration date of the option is in four months, and the price of an option to purchase one barrel is $\$ 5$. The initial investment is $\$ 5000$.

Figure 2.1. Profit from buying a European call option on one barrel of oil. $($ Option price $=\$ 5$, Strike price $=\$ 80)$

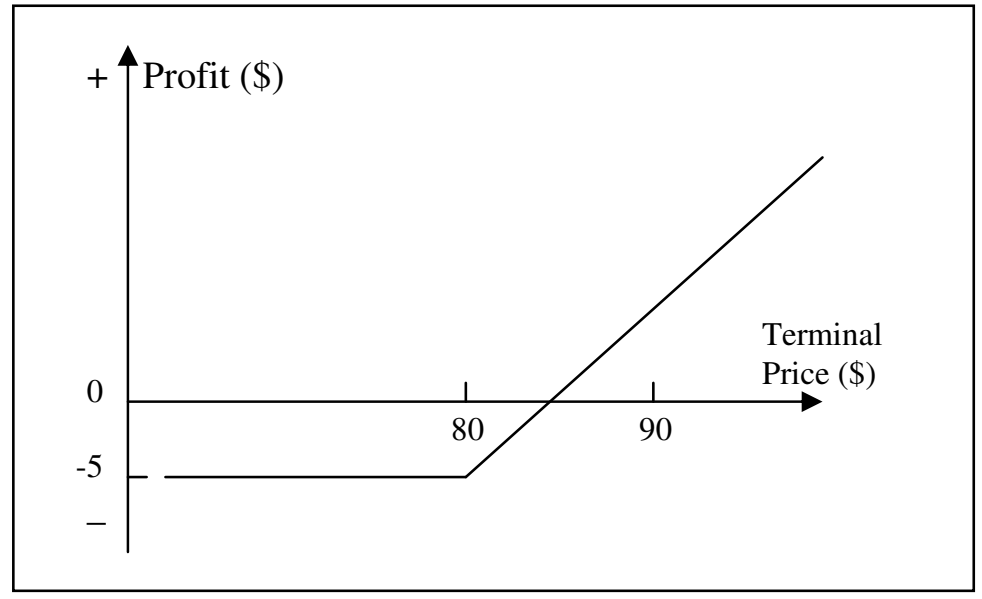

${ }^{102}$ James, 2003, p.108

${ }^{103}$ Pilipovic, 2007, p.224 
If the oil price on this date is less than $\$ 80$, the investor will clearly choose not to exercise. In these circumstances, the investor loses the whole of the initial investment of $\$ 5000$. If the oil price is above $\$ 80$ on the expiration date, the option will be exercised. Suppose, for example, that the oil price is $\$ 95$. By exercising the option, the investor is able to buy 1000 barrels of oil for $\$ 80$ per barrel. If the oil is sold immediately, the investor makes a gain of $\$ 15$ per barrel, or $\$ 15,000$, ignoring transactions costs. When the initial cost of the option is taken into account, the net profit to the investor is $\$ 10,000$.

Figure 2.1 shows how the investor's net profit or loss on an option to purchase one barrel varies with the final oil price in the example. It is important to realize that an investor sometimes exercises an option and makes a loss overall. Suppose that in the example oil price is $\$ 82$ at the expiration of the option. The investor would exercise the option for a gain of $1000 \times(\$ 82-\$ 80)=\$ 2000$ and realize a loss overall of $\$ 3000$ when the initial cost of the option is taken into account. It is tempting to argue that the investor should not exercise the option in these circumstances. However, not exercising would lead to an overall loss of $\$ 5000$, which is worse than the $\$ 3000$ loss when the investor exercises. In general, call options should always be exercised at the expiration date if the commodity's real price is above the strike price. ${ }^{104}$

\subsubsection{Put Option}

A put option gives the buyers the right, but not the obligation, to enter into a short futures position at a predetermined strike price and obligates the seller to assume a long futures position, should the option be exercised.

Whereas the purchaser of a call option is hoping that the commodity price will increase, the purchaser of a put option is hoping that it will decrease. Consider an investor who buys a European put option to sell 1000 equivalents of LNG with a strike price of $\$ 50$. Suppose that the current price LNG equivalent is $\$ 45$, the expiration date of the option is in three months, and the price of an option to sell one equivalent is $\$ 7$. The initial investment is $\$ 7000$. Because the option is European, it will be exercised

${ }^{104}$ Hull, 2003, p.6-7 
only if the terminal price is below $\$ 50$ at the expiration date. Suppose that the price of LNG is $\$ 35$ on this date. The investor can buy 1000 LNG equivalents for $\$ 35$ per equivalent and under the terms of the put option, sell the same amount for $\$ 50$ to realize a gain of $\$ 15$ per equivalent, or $\$ 1,5000$ (transaction costs are ignored). When the $\$ 7000$ initial cost of the option is taken into account, the investor's net profit is $\$ 8000$. There is no guarantee that the investor will make a gain. If the final LNG price is above $\$ 50$, the put option expires worthless, and the investor loses $\$ 7000$. Figure 2.2 shows the way in which the investor's profit or loss on an option to sell one equivalent varies with the terminal LNG price in this example. ${ }^{105}$

Figure 2.2. Profit from buying a European put option on one equivalent of

LNG. $($ Option price $=\$ 7$, Strike price $=\$ 50)$

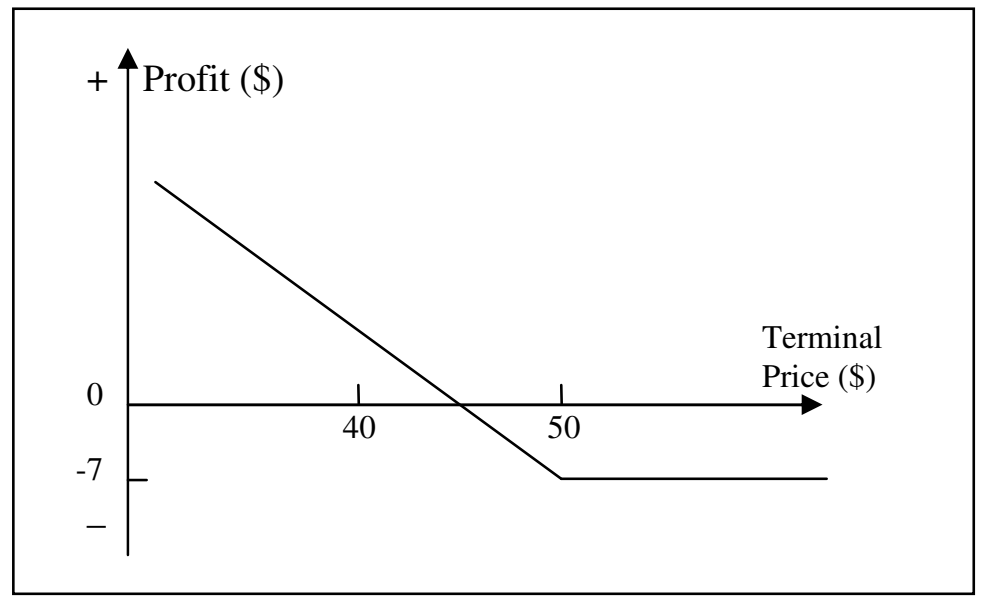

\subsubsection{Styles of Options}

There are European, American and Asian options in energy markets. In energy markets, Asian options represent the majority of contracts, in large part due to the market's need to provide options on averages of prices.

A European option allows for a single exercise date. On that date, the holder of the option can take advantage of the option right if this is profitable. For a European option the exercise date is also the expiration date of the option. An American-style option allows for more than one date as the possible exercise date. There are American

${ }^{105}$ Hull, 2003, p.7-8 
options that allow for a single exercise any day prior to a contract-defined final option expiration date. There are also American options that allow for a single exercise during a particular day in the week or the month until the option expiration. If the option holder exercises her right prior to the final option expiration date, this is referred to as early exercise. American style options are more costly than European options because of their expiration maturity elasticity. ${ }^{106}$

The majority of OTC energy option transactions are made up of Asian-style caps, floors and zero cost collars. Asian options are a type of path-dependent option, sometimes referred to as a look-back option where the buyer has the right to exercise the option at the average price of the underlying energy market over the period of the option. Asian options are cheaper than ordinary European style options because the volatility of an average is lower that the volatility surrounding just one point in time, as is the case for a European style option. In the energy markets we usually deal with quite long averages, and like swaps, Asian options in energy markets tend to cover whole month averages. ${ }^{107}$

\subsubsection{Energy Option Strategies}

Different option strategies like bull and bear spreads, butterfly, calendar or diagonal spread and their combinations are widely applied in energy markets.

\subsection{Spreads}

A spread trading strategy involves taking a position in two or more options of the same type. There are two types of spread strategies due to the price movements Bull and Bear. Investors waiting for the prices to rise in the future are performing bullish strategies. Those who are waiting for the prices to fall are acting in bearish style.

Bull Spreads. One of the most popular types of spreads is a bull spread. It can be created by buying a call option on a commodity with a certain strike price and selling a call option on the same commodity with a higher strike price. Both options have the

\footnotetext{
${ }^{106}$ Pilipovic, 2007, p.258-259

107 James, 2003, p.127
} 
same expiration date. The strategy is illustrated in Figure 2.3. The profits from the two option positions taken separately are shown by the dashed lines. The profit from the whole strategy is the sum of the profits given by the dashed lines and is indicated by the solid line. Because a call price always decreases as the strike price increases, the value of the option sold is always less than the value of the option bought. A bull spread, when created from calls, therefore requires an initial investment. ${ }^{108}$

Figure 2.3. Bull spread created using call options.

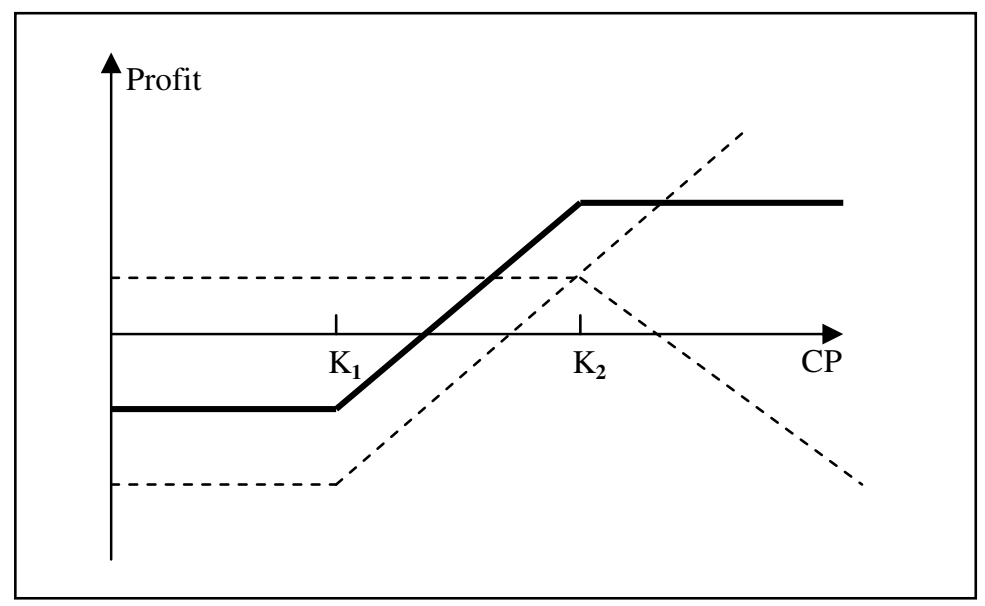

Suppose that $\mathrm{K} 1$ is the strike price of the call option bought, $\mathrm{K} 2$ is the strike price of the call option sold, and CP is the commodity price on the expiration date of the options. If the price does well and is greater than the higher strike price, the payoff is the difference between the two strike prices, or $\mathrm{K} 2-\mathrm{K} 1$. If the price on the expiration date lies between the two strike prices, the payoff is $\mathrm{CP}-\mathrm{K} 1$. If the price on the expiration date is below the lower strike price, the payoff is zero. ${ }^{109}$

Bull spreads can also be created by buying a put with a low strike price and selling a put with a high strike price, as illustrated in Figure 2.4. Unlike the bull spread created from calls, bull spreads created from puts involve a positive cash flow to the investor up front (ignoring margin requirements) and a payoff that is either negative or zero.

\footnotetext{
${ }^{108}$ Hull, 2003, p.187

${ }^{109}$ IBIT, p. 188
} 
Figure 2.4. Bull spread created using put options

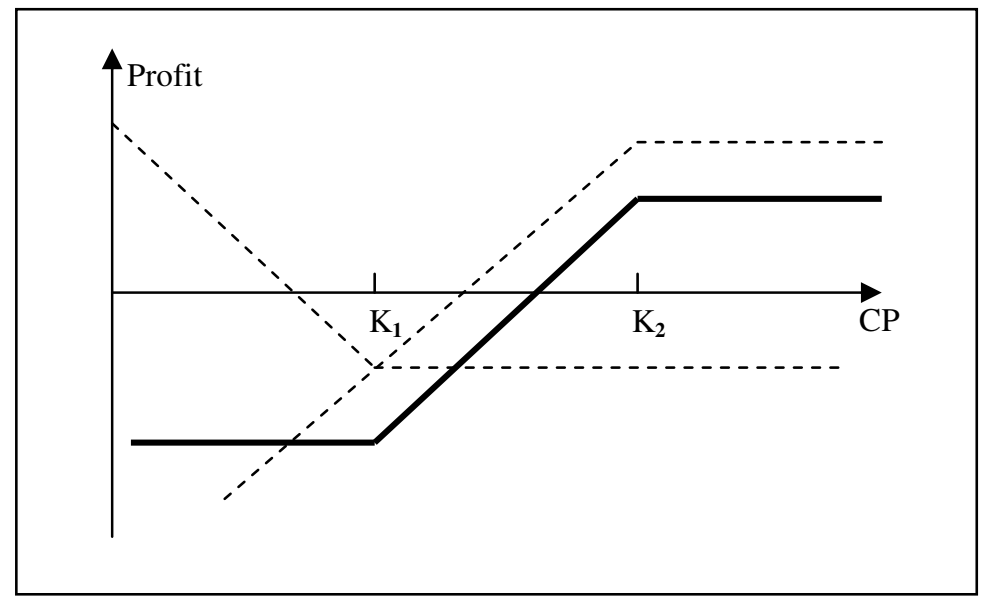

Bear Spreads. An investor who enters into a bull spread is hoping that the commodity price will increase. By contrast, an investor who enters into a bear spread is hoping that the price will decline. As with a bull spread, a bear spread can be created by buying a call with one strike price $\left(\mathrm{K}_{1}\right)$ and selling a call with another strike price $\left(\mathrm{K}_{2}\right)$. However, in the case of a bear spread, the strike price of the option purchased is greater than the strike price of the option sold. In Figure2.5 the profit from the spread is shown by the solid line. A bear spread created from calls involves an initial cash inflow, because the price of the call sold is greater than the price of the call purchased.

Figure 2.5. Bear spread created using call options

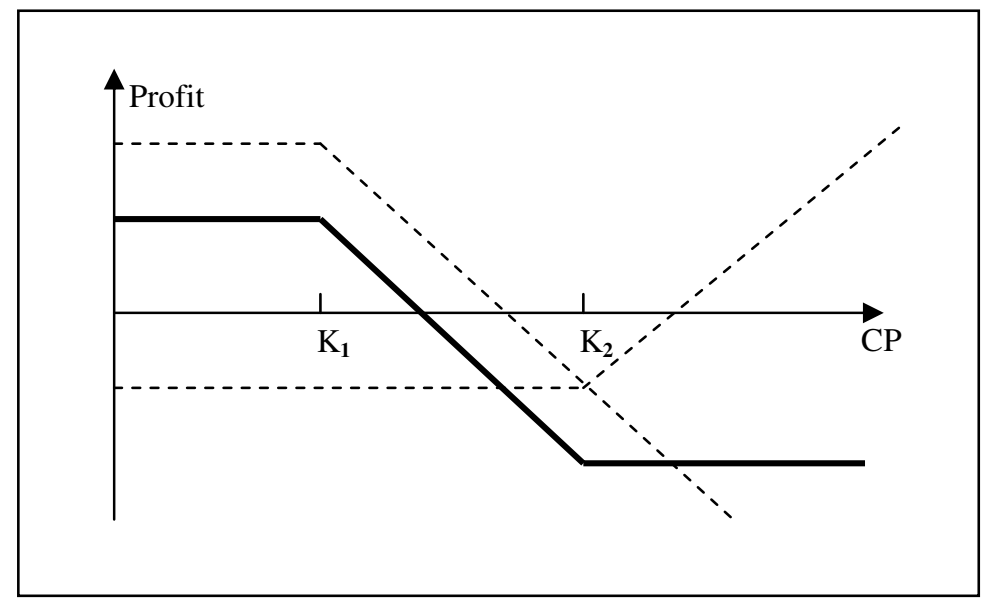




\subsection{Butterfly strategy}

The butterfly is an option strategy that has both limited risk and restricted profit potential (Figure 2.6). It is created by using four strike prices. The strategy may be set up using caps or floor options. Butterfly strategy has an advantage over a straddle and even less risk than a strangle because the structure creates a fixed cap on maximum loss. This is already built into the strategy, so active position management requirements are reduced. ${ }^{110}$

\section{Figure 2.6. Butterfly strategy}

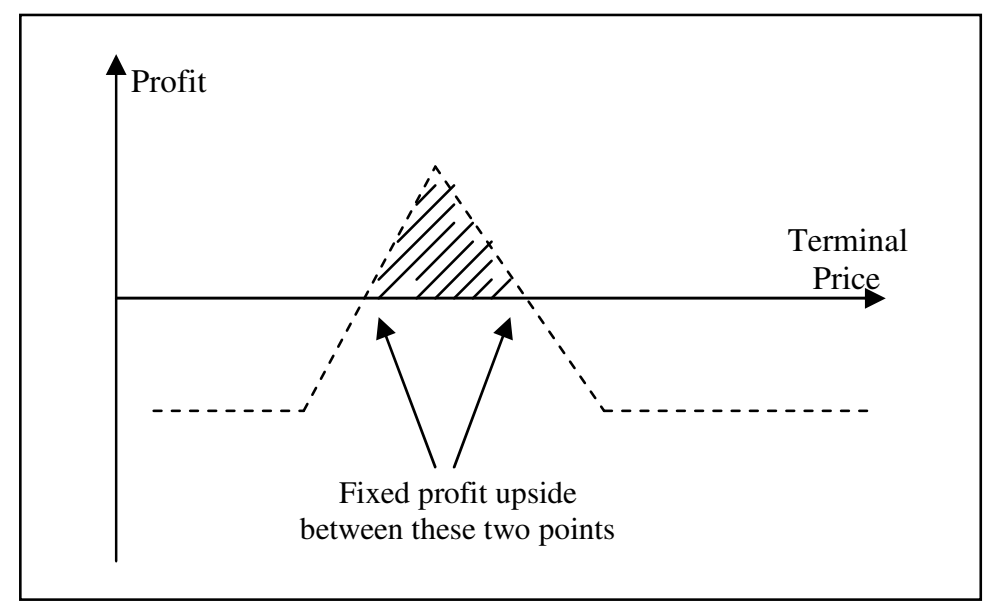

A long (buy) butterfly strategy requires option premiums to be paid. It offers limited risk and is used when the view is that volatility is going to decrease. A short (sell) butterfly strategy receives more premium then premia paid out. It has limited risk and is used when the view is that volatility is going to increase.

\subsection{Calendar Spread}

Calendar spreads is an option strategy in which the options have the same strike price and different expiration dates. A calendar spread can be created by selling a call option with a certain strike price and buying a longer-maturity call option with the same strike price. The longer the maturity of an option, the more expensive it usually is. A calendar spread therefore usually requires an initial investment. Profit diagrams for

${ }^{110}$ James, 2003, p.121 
calendar spreads are usually produced so that they show the profit when the shortmaturity option expires on the assumption that the long-maturity option is sold at that time. However, a loss is incurred when the commodity price is significantly above or significantly below this strike price. ${ }^{111}$

\subsection{Diagonal Spreads}

Bull, bear, and calendar spreads can all be created from a long position in one call and a short position in another call. In the case of bull and bear spreads, the calls have different strike prices and the same expiration date. In the case of calendar spreads, the calls have the same strike price and different expiration dates. In a diagonal spread both the expiration date and the strike price of the calls are different. This increases the range of profit patterns that are possible. ${ }^{112}$

\subsection{Combinations}

A combination is an option trading strategy that involves taking a position in both calls and puts on the same commodity. Here we will consider straddles and strangles.

Straddle is a combination, which involves buying a call and put with the same strike price and expiration date. The Figure 2.7 shows a long position straddle with one call and one put option used.

If the general view of the market is that there will be a big jump in the commodity price soon, that view will be reflected in the prices of options. An investor will find options on the commodity to be significantly more expensive than options on a similar commodity for which no jump is expected. For a straddle to be an effective strategy, the investor must believe that there are likely to be big movements in the price and these beliefs must be different from those of most other market participants. ${ }^{113}$

${ }^{111}$ Hull, 2003, p.192

${ }^{112}$ IBIT, p. 194

${ }^{113}$ IBIT, p.194-195 
Figure 2.7. A straddle

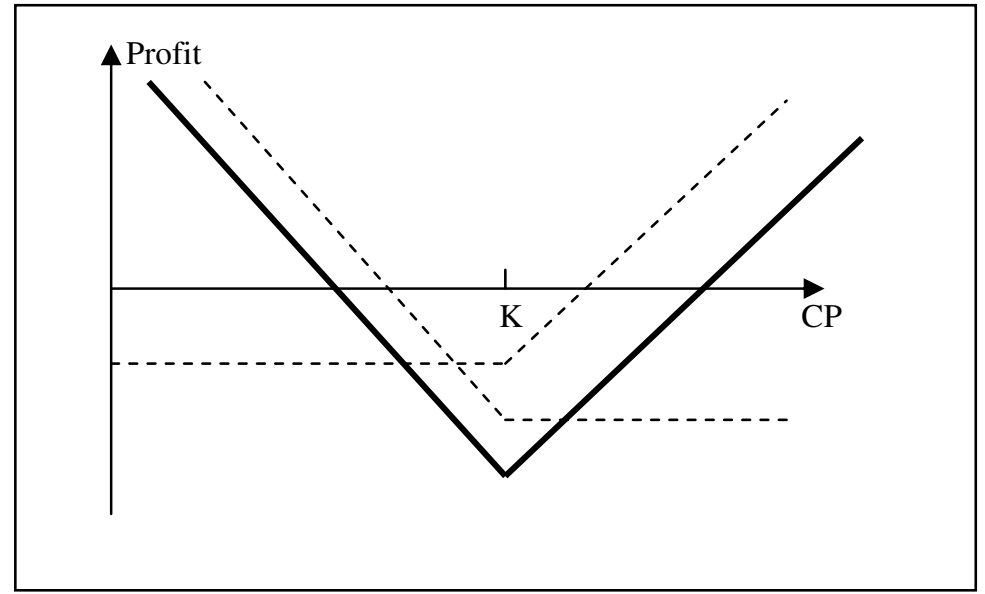

In a strangle, sometimes called a bottom vertical combination, an investor buys a put and a call with the same expiration date and different strike prices. The profit pattern that is obtained is shown in Figure 2.8. The call strike price, $\mathrm{K}_{2}$, is higher than the put strike price, $\mathrm{K}_{1}$.

Figure 2.8. A strangle

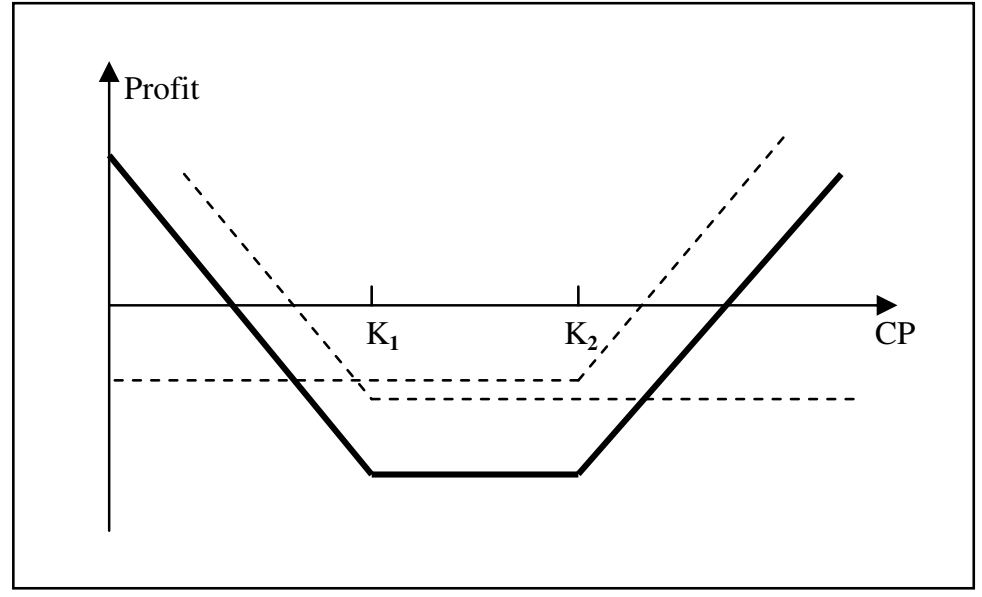

A strangle is a similar strategy to a straddle. The investor is betting that there will be a large price move, but is uncertain whether it will be an increase or a decrease. The profit pattern obtained with a strangle depends on how close together the strike prices are. The farther they are apart, the less the downside risk and the farther the commodity price has to move for a profit to be realized. The sale of a strangle is sometimes referred to as a top vertical combination. It can be appropriate for an investor 
who feels that large price moves are unlikely. However, as with sale of a straddle, it is a risky strategy involving unlimited potential loss to the investor. ${ }^{114}$

\subsubsection{Option Pricing}

American style options are the most preferred types which trade on the major organized energy markets of the world. The best models that are being applied for pricing of these options are the famous Black-Scholes, Binomial tree and the BaroneAdesi-Whaley models. Monte Carlo simulation is the tool to use for Asian options, since when an Asian option is defined in terms of arithmetic averages of the underlying energy price over a one month period, no Black-Scholes or analytical pricing formula is going to be of any use. Monte Carlo simulation is a simulation of many possible paths that the underlying energy price may take. The estimate of value of the option in this case is the average of the expected profit, discounted from the end of the life of the option to the beginning, using the risk free interest rate.

\subsection{Black - Scholes Model}

Black-Scholes is perhaps the most famous option model because it is a simple solution to what can be a complicated problem. The model requires a limited number of data inputs and requires relatively simple mathematical calculations. Although the Black-Scholes model was originally developed just with European options in mind, it can be extended to price American options as well. ${ }^{115}$

The main assumptions underlying the Black and Scholes model to achieve a unique, preference free, price for the option is an arbitrage free market. The markets should be frictionless and continuous. There are no transactions costs or differential taxes, trading takes place continuously, assets are infinitely divisible, unlimited borrowing and short selling are allowed and borrowing and lending rates are equal. According to this model the riskless instantaneous interest rate is constant over time. ${ }^{116}$

\footnotetext{
${ }^{114}$ Hull, 2003, p.196

115 James, 2003, p.128

${ }^{116}$ Henderson, Vicky; Black-Scholes Model, Nomura Centre for Quantitative Finance, Oxford University, 2004, p.5
} 
The Black-Scholes option valuation assumes that the option settlement price is the spot price at the time of option expiration. The mathematical formula of this model is as follows ${ }^{117}$ :

$$
\begin{gathered}
C=S N\left(d_{1}\right)-K e^{-r(T-t)} N\left(d_{2}\right) \\
d_{1}=\frac{\ln (S / K)+\left(r+\frac{\sigma^{2}}{2}\right)(T-t)}{\sigma \sqrt{T-t}} \quad d_{2}=d_{1}-\sigma \sqrt{T-t}
\end{gathered}
$$

In this formula:

$$
\begin{array}{ll}
C-\text { call option price } & S-\text { spot price } \\
K-\text { strike price } & r \text {-discount (risk-free) rate } \\
\sigma-\text { spot price volatility } & T-\text { time of option expiration } \\
t-\text { time of option valuation } & N(d) \text { - cumulative standard deviation } \\
\mathrm{e}-2,71828 \text { (constant) } &
\end{array}
$$

\subsection{Tree Models}

The idea is that we build a tree for the option settlement price that defines the movements, up and down, from node to node, of the option settlement price from now until the time of option expiration. The greater the volatility in the option settlement price, the greater is the up and down jump from node to node. The requirement that there is no arbitrage between current and future value of the settlement price defines the probabilities of going from one node in the tree to another. Thus equipped, we have the values of the settlement price at each node of the tree, as well as the probabilities associated with being at each node of the tree. In this way, we can solve for the option prices backwards: we know what the parity value of the option is at each node of the tree at the expiration time and we know what the probabilities are. We can then move backwards in time through the tree to arrive ultimately at the present value of the

\footnotetext{
${ }^{117}$ Pilipovic, 2007, p.277
} 
option's price. Trees can be relatively easy to build and use in option pricing. ${ }^{118}$ The tree model consisting of one period until option maturity is called binomial tree. The models assuming more than one period are trinomial trees.

\subsection{Barone-Adesi Whaley Model}

Options written on a wide variety of commodities and commodity futures contracts now trade in the World. Nearly all these options are American style and thus have early exercise premiums implicitly embedded in their prices. Unlike the Europeanstyle option-pricing problems, however, analytic solutions for the American optionpricing problems have not been found, and the pricing of American options has usually resorted to finite-difference, binomial, or, more recently, compound-option approximation methods. ${ }^{119}$

Option calculators will often use the Barone-Adesi and Whaley method. This method prices an American option by valuing the corresponding European option using the Black-Scholes method and then adds on an early exercise premium. Since unlike European style options, an American style option can be exercised on any day and at any time up to and including its expiry date if the underlying price exceeds some market price level calculated by the model. However, this model cannot be applied to Asian options. $^{120}$

\subsubsection{Energy Swap Contracts}

Energy swaps are the most recent derivatives in financial markets, dating from the early 1980s. An energy swap is an agreement to exchange cash flows in the future according to some agreed upon formula. Energy swaps are bilateral OTC agreements. These agreements, which does not require up-front payments, stipulates the amount of the commodity covered by the swap, the length of the agreement, the price index that is the basis for the financial swap, and the frequency of payment. Fewer than three months is considered short term holding period for swaps, while long term is from six months to

\footnotetext{
${ }^{118}$ Pilipovic, 2007, p.290-291

${ }^{119}$ Barone-Adesi, Giovanni and Whaley, Robert E.; Efficient Analytic Approximation of American Options Values, The Journal of Finance, Vol.42, No:2, 1987, p.301

${ }^{120}$ James, 2003, p.128
} 
30 years. Thus, swaps can provide much longer-term protection than futures contracts. $^{121}$

In a basic "fixed for floating" swap, the underlying is some fixed amount of a commodity on which payments are based but which never physically changes hands. Producers are natural swap sellers (receivers of fixed) while end-users are natural buyers (payers of fixed). Intermediaries are important for ensuring confidentiality, assuming credit risk, and being able to absorb residual market risk which may arise from contracts with slightly different terms. ${ }^{122}$

Figure 2.9. Crude Oil Swap Contract Between an Oil Producer and a Refiner

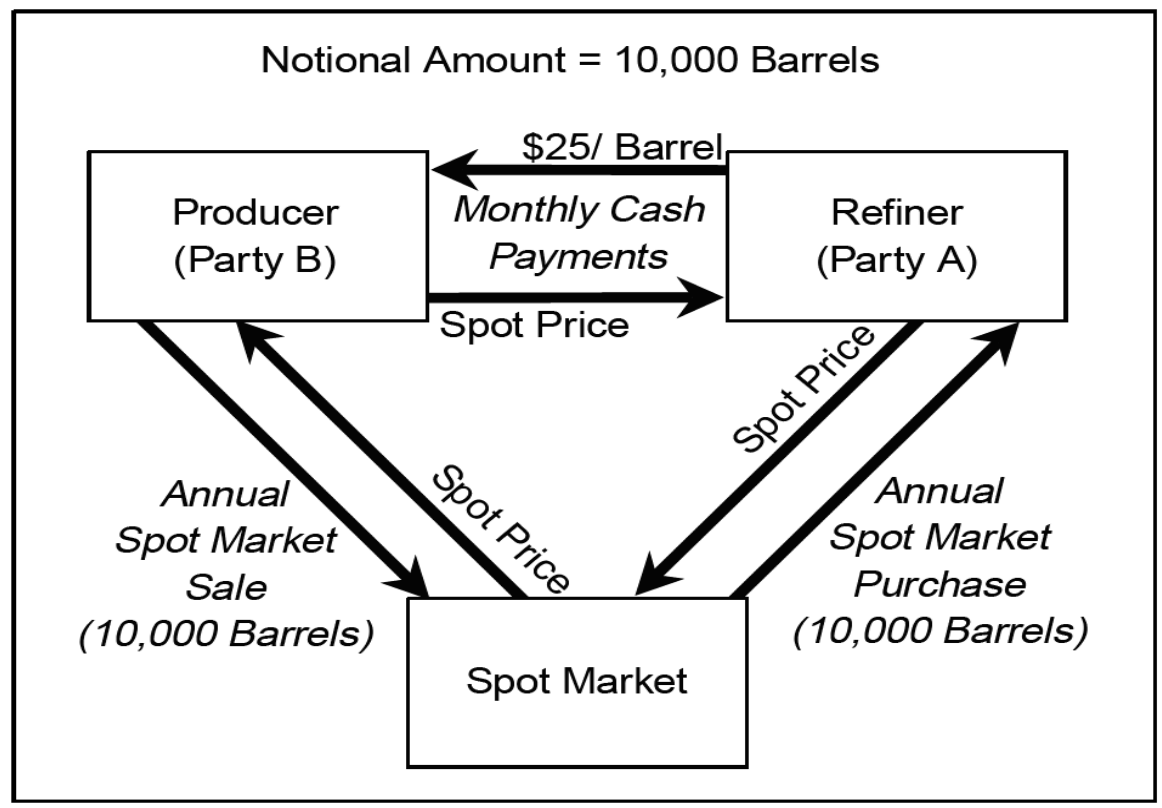

Figure 2.9. illustrates an example of a standard crude oil swap. In the example, a refiner and an oil producer agree to enter into a 10-year crude oil swap with a monthly exchange of payments. ${ }^{123}$ The refiner (Party A) agrees to pay the producer (Party B) a fixed price of $\$ 25$ per barrel, and the producer agrees to pay the refiner the settlement price of a futures contract for NYMEX light, sweet crude oil on the final day of trading

\footnotetext{
${ }^{121}$ Dahl, 2004, p.411

${ }^{122}$ McCann, Karen and Nordström, Mary; Energy Derivatives: Crude Oil and Natural Gas, Federal Reserve Bank Of Chicago,1995, p.4

${ }^{123}$ Hale, 2002, p.8
} 
for the contract. The notional amount of the contract is 10,000 barrels. Under this contract the payments are netted, so that the party owing the larger payment for the month makes a net payment to the party owing the lesser amount. If the NYMEX settlement price on the final day of trading is $\$ 23$ per barrel, Party A will make a payment of $\$ 2$ per barrel times 10,000 , or $\$ 20,000$, to Party B. If the NYMEX price is $\$ 28$ per barrel, Party B will make a payment of \$30,000 to Party A. The 10-year swap effectively creates a package of 120 cash-settled forward contracts, one maturing each month for 10 years.

Although swaps can be highly customized, the counterparties are exposed to higher credit risk because the contracts generally are not guaranteed by a clearinghouse as are exchange-traded derivatives. In addition, customized swaps generally are less liquid instruments, usually requiring parties to renegotiate terms before prematurely terminating or offsetting a contract. ${ }^{124}$

Swaps have not traditionally traded on exchanges until NYMEX introduced swaps trading for 25 common products on May 31, 2002. Although NYMEX swaps remain bilateral and provisions are confidential, the exchange provides default insurance by guaranteeing both sides of the transactions. Parties must maintain margins and the contracts are marked-to-market. ${ }^{125}$

\subsubsection{Types of Energy Swaps}

Energy Swaps can be classified as plain vanilla, differential and participation swaps.

Plain vanilla swap (Figure 2.10) is a monthly averaging swap. In these agreements fixed prices are exchanged (swapped) versus floating prices in the future. Plain vanilla swaps are used extensively in Oil, LPG and LNG related hedging and

\footnotetext{
${ }^{124}$ Hale, 2002, p.9

${ }^{125}$ Dahl, 2004, p.411
} 
trading. When executing the deal counterparts discuss the fixed price agreed today and which floating price reference they will use to calculate the settlement ${ }^{126}$.

Assume that, counterpart A buys fixed price 15.00 (buys fixed, sells floating). Counterpart B sells fixed price 15.00 (sells fixed, buys floating). Floating price reference is chosen, e.g. Platts average during the price period June $2009=16.00$.

Figure 2.10. Plain vanilla swap

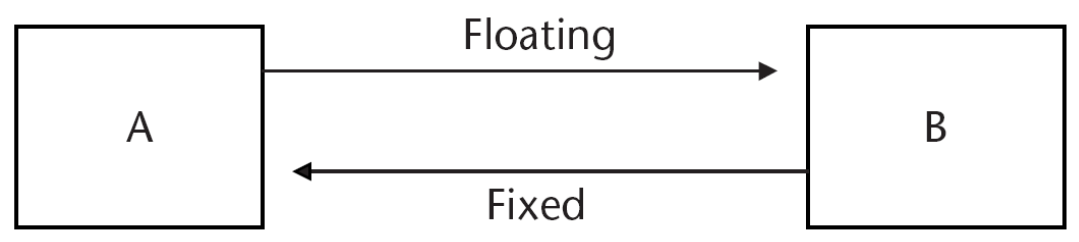

Net Result:

- Counterpart $\mathrm{A}=+\$ 1.00$ (difference between fixed/floating)

- Counterpart $\mathrm{B}=-\$ 1.00$

- Counterpart B pays Counterpart A US\$1.00. Only the difference is exchanged, not the principal notional amount.

Differential swap is like a plain vanilla swap except that instead of one fixed price versus a floating price, it is based on the difference between fixed prices in two products. Differential swaps are used across the whole energy spectrum. In the power and gas markets we see "spark spreads", where hedgers and traders use derivatives pricing against the difference between power and gas markets. In the oil sector, the most popular differential swap is the Jet Kero versus Gasoil (Figure 2.4), commonly termed the "regrade" swap. ${ }^{127}$

\footnotetext{
${ }^{126}$ James, 2003, p.16

${ }^{127}$ IBIT, p. 17
} 
Figure 2.11. Differential swap

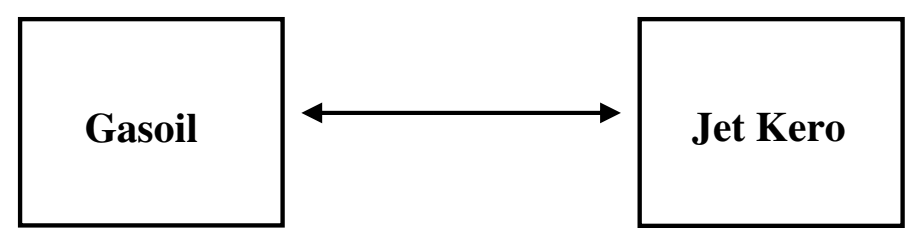

Let's assume that, counterpart A buys fixed price Kero and sells fixed price Gasoil at a difference of US\$0.50 per barrel Kero premium. Counterpart B sells fixed price Kero and buys fixed price Gasoil at a difference of US\$0.50 per barrel Kero Premium. Floating price reference is chosen, e.g. Platts Kero and Gasoil average difference during the price period June $2009=0.60$ Kero premium.

Net Result:

- Counterpart $\mathrm{A}=+\$ .10$ (difference between fixed differential and the floating differential)

- Counterpart $\mathrm{B}=-\$ 0.10$ cents per barrel

- Counterpart B pays Counterpart A US\$0.10. Only the difference is exchanged, not the principal notional amount.

Participation swaps contract establishes a minimum average forward sale price, while offering between $25 \%-100 \%$ participation in upward price moves. It is an attractive alternative to many other producer hedging strategies because it overcomes the problem of forfeited upside price movements in a conventional swap. Because of the forward sale, the Producer achieves complete price protection from any decrease in oil prices. If prices rise instead, the Producer participates in the favorable price move at the participation rate once average prices rise above the forward sale level. The participation swap strategy outperforms the basic swap if prices rise sufficiently. It is most appropriate if strong upward price moves are expected, yet prices also seem vulnerable to sudden downward spikes. The Producer sells forward, establishing a minimum average sale price. There is not an up-front payment for participation swaps. 


\subsubsection{Pricing Energy Swaps}

Let $S_{i}$ be the spot price of a commodity at the beginning of period $i$. Party $A$ receives the spot price for $N$ units of the commodity and pays a fixed amount, $X$, per period. We will assume that payments take place at the beginning of the period and there will be a total of $M$ payments, beginning one period from now. The cash-flow as seen by the party that is long the swap will be as follows ${ }^{128}$ :

$$
C=N \times\left(0, S_{1}-X, S_{2}-X, \ldots, S_{M}-X\right)
$$

Note that this cash-flow is stochastic and so we cannot compute its present value directly by discounting. However, we can decompose $\mathrm{C}$ into a stream of fixed payments (of $-\mathrm{NX})$ that we can easily price, and a stochastic stream, $\mathrm{N}\left(0, \mathrm{~S}_{1}, \mathrm{~S}_{2}, \ldots\right.$, $\mathrm{S}_{\mathrm{M}}$ ). The stochastic stream is easily seen to be equivalent to a stream of forward contacts on $\mathrm{N}$ units of the commodity. We then see that receiving $\mathrm{NS}_{i}$ at period $i$ has the same value of receiving $\mathrm{NF}_{i}$ at period $i$ where $\mathrm{F}_{i}$ is the date 0 forward price for delivery of one unit of the commodity at date $i$. As the forward prices, $\mathrm{F}_{i}$, are deterministic and known at date 0 , we can see that the value of the commodity swap is given by:

$$
V=N \sum_{i=1}^{M} d(0, i)\left(F_{i}-X\right)
$$

\subsection{Weather Derivatives and Energy Markets}

Weather derivatives are a form of financial instrument similar in nature to the commodity futures contracts and options, but their price is tied to some facet of the weather and climate such as temperature, precipitation, wind, and heating (cooling) degree-days. Firms that participate in weather derivative markets are often involved in activities that are weather sensitive. Through weather derivatives, these firms seek to reduce their weather related risks. Some participants use these markets to speculate on

\footnotetext{
${ }^{128}$ Haugh, Martin; Forwards, Swaps and Futures, Financial Engineering: Discrete-Time Asset Pricing, Fall 2005, p.5
} 
the future weather. Weather derivative contracts are traded both over the counter through some intermediary, such as a merchant bank and also via open markets. ${ }^{129}$

\subsubsection{Weather Derivatives Contracts}

Weather derivatives are usually structured as swaps, futures, and call/put options based on different underlying weather indices. Some commonly used indices are heating degree-days (HDD) and cooling degree-days (CDD), rain and snowfall. The degree-days indices are the most often used. ${ }^{130}$

A degree day is the deviation of the average daily temperature from a predefined temperature. Since HDDs and CDDs are measuring heating and cooling needs compared to the base temperature, they are calculated according to the following equations. ${ }^{131}$ Given a specific weather station, let $T_{i}^{\max }$ and $T_{i}{ }^{\min }$ denote the maximal and minimal temperatures measured on day $i$. We define the temperature for day $i$ as:

$$
T_{i} \equiv \frac{T_{i}^{\max }+T_{i}^{\min }}{2}
$$

We define the heating degree-days, $H D D i$ and the cooling degree-days, $C D D i$, generated on that day as:

$$
H D D_{i} \equiv \max \left\{18-T_{i}, 0\right\} \quad C D D_{i} \equiv \min \left\{T_{i}-18,0\right\}
$$

Above, we see that the number of HDDs or CDDs for a specific day is just the number of degrees that the temperature deviates from a reference level. It has become industry standard in the US to set this reference level at $65^{\circ}$ Fahrenheit $\left(18^{\circ} \mathrm{C}\right)$. The names heating and cooling degree-days originate from the US energy sector. The reason is that if the temperature is below $18^{\circ} \mathrm{C}$ people tend to use more energy to heat their

\footnotetext{
${ }^{129}$ Stren, Harvey and Dawkins, Shoni S.; Weather Derivatives As a Vehicle to Realise The Skill of Seasonal Forecasts, Bureau of Meteorology, Melbourne, Australia, 2003, p.1-2

${ }^{130}$ Alaton, Peter, Boualem, Djehiche and David Stillberger; On Modelling and Pricing Weather Derivatives, Applied Mathematical Finance, Vol. 9, Issue 1, 2002, p.3

${ }^{131}$ Dunis, Christian L. and Vassilios Karalis; Weather Derivatives Pricing and Filling Analysis for Missing Temprature Data, Liverpool Business School and CIBEF, 2003, p.3
} 
homes, whereas if the temperature is above $18^{\circ} \mathrm{C}$ people start turning their air conditioners on, for cooling. Typically the HDD season includes winter months from November to March and the CDD season is from May to September. April and October are often referred to as the "shoulder months". 132

Monthly HDD and CDD can be formulated as follows ${ }^{133}$ :

$$
C D D_{M} \equiv \sum_{i=1}^{n(M)} c d d_{i} \quad H D D_{M}=\sum_{i=1}^{n(M)} h d d_{i}
$$

Here $n(M)$ is the number of days in month $M$.

A generic weather derivative contract can be formulated by specifying seven parameters such as contract type (swap, call, or put), contract period, an official weather station from which the meteorological record is obtained, definition of the underlying weather index, strike for put/call or exercise index for swap, tick for a linear payout scheme or the fixed payment for a binary payment scheme and premium for call and put. ${ }^{134}$

\subsubsection{Types of Weather Derivatives}

Weather derivatives are structured as swap, call, and put contracts based on weather indexes ${ }^{135}$. Payoffs are usually defined as a specified dollar amount (e.g. \$1000 per degree day) multiplied by differences between the "strike" HDD (CDD) level specified in the contract and the actual cumulative HDD (CDD) level which occurred during the contract period. In order to limit the maximum payout by any of the counterparties, the contracts are usually "capped". Only a maximum amount of payout can change hands. ${ }^{136}$

\footnotetext{
${ }^{132}$ Alaton, Djehiche and Stillberger, 2002, p.3-4

${ }^{133}$ Dvortsov, Victor; The Use of Weather Derivatives Energy Industriy, 2004, p.7

${ }^{134}$ Lixin, Zeng; Pricing weather Derivatives, Journal of Risk Finance, Vol:1, 2000, p.73

135 IBIT, p.72

${ }^{136}$ Garman, Mark; Blanco, Carlos and Erickson, Robert; Weather Derivatives, Insturments and Pricing Issues, Envorimental Finance, March 2000, p.3
} 


\subsubsection{Weather Swaps}

In most swaps, payments are made between the two parties, with one side paying a fixed price and the other side paying a variable price. In one type of weather swap that is often used, there is only one date when the cash-flows are swapped, as opposed to interest rate swaps, which usually have several swap dates. The swaps with only one period can therefore be thought of as forward contracts. Often the contract periods are single calendar months or a period such as January-March. In the case of a standard HDD swap, the parties agree on a given strike of HDDs for the period, and the amount swapped is, for example, 10000 euro/HDD away from the strike. Usually there is also a maximum payout corresponding to 200 degree-days. ${ }^{137} \mathrm{~A}$ swap is a combination of a call and put option with the same strike and on the same underlying location. Degree day swaps can provide revenue stability. The payoff is:

$$
\operatorname{Min}\left(p(\$ / D D) \times \operatorname{Max}\left\{0, X_{t / T}-K\right\}, h\right)-\operatorname{Min}\left(p(\$ / D D) \times \operatorname{Max}\left\{0, K-X_{t / T}\right\}, h\right)
$$

An investor who is long the swap will receive payments if the recorded HDD or CDD are greater than the strike, and will make payments if the recorded HDDs or CDDs are lower than the strike.

\subsubsection{Weather Options}

Since, weather is not in fact a tradable asset, a dollar amount is associated with every degree day in the payoff calculation. Generally, the payoffs of the weather puts and calls can be represented as ${ }^{138}$ :

Payoff Call : $p(\$ / D D) \times \operatorname{Max}\left(0, X_{t / T}-K\right)$

Payoff Put : $p(\$ / D D) \times \operatorname{Max}\left(0, K-X_{t / T}\right)$

Here $p(\$ / D D)$ is the per degree day payoff. $X_{t T}$ is the underlying (CDD or HDD), and $K$ is the strike denominated in terms of the associated underlying measure.

\footnotetext{
${ }^{137}$ Alaton, Djehiche and Stillberger, 2002, p.5

${ }^{138}$ Garman, Blanco and Erickson, 2003, p.3
} 
The buyer of a HDD call, for example, pays the seller a premium at the beginning of the contract. In return, if the number of HDDs for the contract period is greater than the predetermined strike level, the buyer will receive a payout. The size of the payout is determined by the strike and the tick size. The tick size is the amount of money that the holder of the call receives for each degree-day above the strike level for the period. ${ }^{139}$

\subsubsection{Weather Derivatives vs Insurance Contracts}

The main difference between derivatives and insurance contracts is that the holder of an insurance contract has to prove that he has suffered a financial loss due to weather in order to be compensated. Payouts of weather derivatives are based only on the actual outcome of the weather, regardless of how it affects the holder of the derivative. One does not need to have any weather sensitive production, for example, to buy and benefit from a weather derivative. As any derivatives, these contracts can be bought for mere speculation.

Insurance contracts are usually designed to protect the holder from extreme weather events such as earthquakes and typhoons, and they do not work well with the uncertainties in normal weather. Weather derivatives, on the other hand, can be constructed to have payouts in any weather condition.

There is another important advantage of derivative contracts compared to insurance contracts. There may be two actors on the market, one of which will make profits if there is a very cold winter, whereas the other will benefit from a warm winter. In a derivatives market these two actors can meet and enter a contract such that they will hedge each other's risks. This is not possible in the insurance market. ${ }^{140}$ For example, a heating oil retailer may feel that if the winter is very cold it will have high revenues, so it might sell a Heating Degree Days call. If the winter is not particularly cold, the oil retailer keeps the premium of the call. On the other hand, if the winter is very cold, the retailer can afford to finance the payout of the option because its revenues are high. The company has thus reduced its exposure to weather risk.

\footnotetext{
${ }^{139}$ Alaton, Djehiche and Stillberger, 2002, p.4

${ }^{140}$ IBIT, p.5
} 


\section{WORLD ENERGY DERIVATIVE MARKETS}

Commodity markets are rapidly changing. The emergence of new financial centers, the deregulation of older markets, financial and technological innovations all combine to change the market landscape. Older markets apply a variety of strategies to adapt to new realities, ranging from consolidation to development of new technologies and new lines of business.

Until recently it appeared that the future belonged to over-the-counter (OTC) markets, where large institutions trade among themselves with no intermediaries. However, the lack of transparency of OTC markets has been a major determinant of the 2007 crisis of credit markets. Open outcry exchanges may recover some of their appeal as a result of this crisis. They may be more expensive, but they offer better opportunities for price discovery and contract enforcement. ${ }^{141}$

\subsection{EVOLUTION OF ENERGY DERIVATIVE MARKETS}

The economic environment spanned by financial globalization enhances opportunities for trading derivatives on commodities and financial assets. Liberalization of the economy implies market deregulation and often leads to the privatization of industries previously considered to be natural monopolies. The aim of this process is to improve economic performance. However these steps are not sufficient if competition is not ensured. Therefore market design plays a crucial role for economic growth. ${ }^{142}$

Traditionally, the energy industry has favoured over-the-counter derivatives which can be customised to meet the needs of both counterparts to the deal. However, some companies have found drawbacks to the OTC market such as a lack of liquidity or price transparency. But these problems should be ironed out as the OTC market

\footnotetext{
${ }^{141}$ Geman, Helyette; Risk Management In Commodity Markets, Chichester: John Wiley \& Sons Ltd., 2008, p. 52

${ }^{142}$ IBIT, p.51
} 
converges with the on-exchange market to provide a more effective and efficient service to all parties concerned. ${ }^{143}$ Despite all disadvantages of OTC markets, the regulated futures exchanges seem to be unable to launch new petroleum futures contracts very often. This is because the needs of the market are already being met by the now wellestablished and liquid OTC derivatives market. Another factor of this observation is that futures exchanges have been successful in launching futures contracts in both the natural gas and power markets. The reason for this is that the regulated futures markets were launched soon after deregulation prior to or at the same time as an OTC market was establishing itself. ${ }^{144}$

Exchanges, energy traders, and electronic bulletin boards, investment banks and insurance companies compete vigorously for business in energy derivatives. Society relies on competition within and across these markets to ensure that risk is transferred at least cost. The exchanges and OTC traders have designed derivatives that respond to the concerns of market participants while recognizing the limits of location arbitrage, the importance of input-output price spreads to profits, and the role of price controls in retail energy markets. ${ }^{145}$

The world derivatives industry has made an enormous positive step forward in the last decade. At year-end 1999, as we entered the new millennium, volume on U.S. futures exchanges had fallen 7\%. But thanks to an $11 \%$ increase on non-U.S. exchanges, global volume actually rose $10 \%$ that year to 2.4 billion contracts traded. ${ }^{146}$ Just 10 years later, global volume stands an astonishing 646\% higher at 15.5 billion contracts traded. $^{147}$ (Table 3.1) Energy products transactions took a considerable part within commodities market with a volume of 580 million and showed a $16.8 \%$ increase in year 2008 .

\footnotetext{
143 James, 2003, p.24

${ }^{144}$ IBIT, p.74

${ }^{145}$ Hale, 2002, p.23-24

${ }^{146}$ Burghardt, Galen; 9.899.780.283 Contracts Traded, Futures Industry, 2006, March/April, p.16-17.

${ }^{147}$ Burghardt, Galen and Acworth, Will; 2008 - A Wild Ride, Futures Industry, 2009, March, p.16-19
} 
Table 3.1. Global listed derivatives volume by category

\begin{tabular}{|c|c|c|c|}
\hline Category & Jan-Dec 2008 & Jan-Dec 2007 & \% Change \\
\hline Equity Index & $6,488,620,434$ & $5,499,833,555$ & $18.0 \%$ \\
\hline Individual Equity & $5,511,194,380$ & $4,400,437,854$ & $25.2 \%$ \\
\hline Interest Rates & $3,204,838,617$ & $3,745,176,350$ & $-14.4 \%$ \\
\hline Agricultural & $888,828,194$ & $640,683,907$ & $38.7 \%$ \\
\hline Energy & $580,404,789$ & $496,770,566$ & $16.8 \%$ \\
\hline Currency & $577,156,982$ & $459,752,816$ & $25.5 \%$ \\
\hline Precious Metals & $180,370,074$ & $150,976,113$ & $19.5 \%$ \\
\hline Non-Precious Metals & $175,788,341$ & $106,859,969$ & $64.5 \%$ \\
\hline Other & $45,501,810$ & $26,140,974$ & $74.1 \%$ \\
\hline Total & $17,652,703,621$ & $15,526,632,104$ & $13.7 \%$ \\
\hline
\end{tabular}

Source: Burghardt and Acworth, Futures industry, 2009, March, p.17

Futures markets have been used by traders in commodities for hundreds of years, beginning with the trading of rice futures in Osaka, Japan, in the late 1600s. But the successful petroleum futures contracts first appeared in the end of XX century. In 1978 NYMEX introduced futures contracts on both No. 2 heating oil and No. 6 fuel oil. The No. 6 contract failed because utilities, the largest purchasers of No. 6 fuel oil, were able to pass the risk of escalating prices on to their customers by means of fuel adjustment clauses. Therefore, they did not need the futures market to minimize price risk. The No. 2 contract has been successful, however, because heating oil is bought and sold by a large number of market participants. ${ }^{148}$ The heating oil market is also active year-round: inventories are built up in the off season and worked off in the winter to meet seasonal demands.

Trading volume in successful contracts can climb dramatically. For example, the annual trading volumes of the No. 2 heating oil contract grew from 25,910 in 1978 to more than 932,000 in 1980 , to 5.7 million in 1989 , and to a record 9.6 million in $2000 .{ }^{149}$ And, as energy futures contracts become more liquid, exchanges usually launch

\footnotetext{
${ }^{148}$ Hale, 2002, p.23-24

${ }^{149}$ IBIT, p. 25
} 
options contracts. Exchange-traded options contracts are usually launched after 10,000 to 20,000 lots of open interest are developed in the futures contract. Options on energy futures are traded on the same exchanges that trade the underlying futures contracts and are standardised with respect to the quantity of the underlying futures contracts, expiration date, and strike price. Options trading models are very well developed for energy trading in oil and gas futures. ${ }^{150}$

Table 3.2. Top 20 energy futures and options worldwide

\begin{tabular}{|c|c|c|c|c|}
\hline Rank & Contract & $\begin{array}{r}\text { Jan-Dec } \\
2008\end{array}$ & $\begin{array}{r}\text { Jan-Dec } \\
2007\end{array}$ & \% Change \\
\hline 1 & Light, Sweet Crude Oil Futures, CME & $134,674,264$ & $121,525,967$ & $10.8 \%$ \\
\hline 2 & Brent Crude Oil Futures, ICE Futures Europe & $68,368,145$ & $59,728,941$ & $14.5 \%$ \\
\hline 3 & WTI Crude Oil Futures, ICE Futures Europe & $51,091,712$ & $51,388,362$ & $-0.6 \%$ \\
\hline 4 & Natural Gas Futures, CME & $38,730,519$ & $29,786,318$ & $30.0 \%$ \\
\hline 5 & Light Sweet Crude Oil Options on Futures, CME & $35,255,326$ & $28,398,793$ & $24.1 \%$ \\
\hline 6 & Henry Hub Natural Gas Swap Futures, CME & $31,401,575$ & $16,207,044$ & $93.8 \%$ \\
\hline 7 & European Style Natural Gas Options, CME & $31,158,326$ & $29,921,068$ & $4.1 \%$ \\
\hline 8 & Fuel Oil Futures, SHFE & $30,810,540$ & $12,005,094$ & $156.6 \%$ \\
\hline 9 & Gas Oil Futures, ICE Futures Europe & $28,805,192$ & $24,509,884$ & $17.5 \%$ \\
\hline 10 & NY Harbor RBOB Gasoline Futures, CME & $20,522,571$ & $19,791,439$ & $3.7 \%$ \\
\hline 11 & Crude Oil Futures, MCX & $20,507,001$ & $13,938,813$ & $47.1 \%$ \\
\hline 12 & No. 2 Heating Oil Futures, CME & $19,583,052$ & $18,078,976$ & $8.3 \%$ \\
\hline 13 & Henry Hub Penultimate Swap Futures, CME & $12,352,928$ & $10,117,889$ & $22.1 \%$ \\
\hline 14 & miNY Crude Oil Futures, CME & $5,641,145$ & $5,185,214$ & $8.8 \%$ \\
\hline 15 & Gasoline Futures, Tocom & $4,054,761$ & $7,529,706$ & $-46.1 \%$ \\
\hline 16 & European Style Crude Oil Options, CME & $3,580,861$ & $1,879,999$ & $90.5 \%$ \\
\hline 17 & Natural Gas Options on Futures, CME & $2,336,287$ & $5,051,879$ & $-53.8 \%$ \\
\hline 18 & Crude Oil Average Price Options, CME & $2,227,738$ & $1,445,930$ & $54.1 \%$ \\
\hline 19 & Panhandle Basis Natural Gas Swap Futures, CME & $2,017,371$ & $1,497,748$ & $34.7 \%$ \\
\hline 20 & ECX CFI Futures, European Climate Exchange & $1,991,276$ & 980,780 & $103.0 \%$ \\
\hline
\end{tabular}

Source: Burghardt and Acworth, Futures industry, 2009, March, p.28

Today, NYMEX is the largest energy futures exchange in the world, which trades oil, gas, electric power and coal contracts. Other oil and gas futures markets include the IPE in London, which trades oil and gas contracts, and the Tokyo Commodity Exchange in Tokyo, which trades small oil futures contracts. The Singapore Exchange used to trade fuel oil futures contracts in the past and now has relationships with other energy futures exchanges for electronic trading. The Shanghai Futures

\footnotetext{
${ }^{150}$ Fusaro, Peter; The Energy Markets, PRMIA I.C.8, 2004, p.10
} 
Exchange (SHFE) launched a fuel oil futures contract in August 2004 and also has a number of linkages to NYMEX, the IPE and the Singapore Exchange. ${ }^{151}$

The major oil futures contracts are NYMEX light sweet crude oil futures, NYMEX heating oil futures, NYMEX gasoline futures, IPE Brent crude oil futures, and IPE gasoil futures (NYMEX operates under CME Group and ICE holds the ownership of IPE.) Natural gas futures contracts are only traded on the NYMEX and IPE. The NYMEX Henry Hub natural gas futures contract is considered the global benchmark for gas trading, and recently has been used for LNG hedging purposes. It was launched in 1990. The IPE's natural gas futures contract is more regionalised for the UK's National Balancing Point (NBP price reference) and was launched in 1997.

There are a number of electricity exchanges which trade both physical spot electricity and electricity futures, but the three largest are NordPool in Scandinavia, the European Energy Exchange (EEX) in Germany and the UK Power Exchange (UKPX). NordPool is the most liquid electricity trading market in the world. It trades OTC, bilateral, cleared OTC, and physical forward electricity contracts. EEX trades both physical spot electricity and electricity futures and is the consolidation of two German exchanges. UKPX provides a market for trading in both spot and futures contracts in electricity. It also acts as a clearing house for OTC transactions. Electricity is also traded on the NYMEX for the eastern United States in its PJM3 and NYISO4 electricity futures contracts. ${ }^{152}$

In recent years more and more countries have founded exchanges for electricity. Some of them are only a marketplace for spot products, but the major exchanges are characterised by the existence of a derivative market with a high trading volume. Most electricity exchanges are located in Europe and North America. The map in Figure 3.1 shows the location of some electricity exchanges worldwide. ${ }^{153}$

${ }^{151}$ Fusaro, The Energy Markets, 2004, p.6

${ }^{152}$ IBIT, p. $7-9$

${ }^{153}$ Burger, 2007, p.33 
Figure 3.1. Locations of exchanges trading electricity

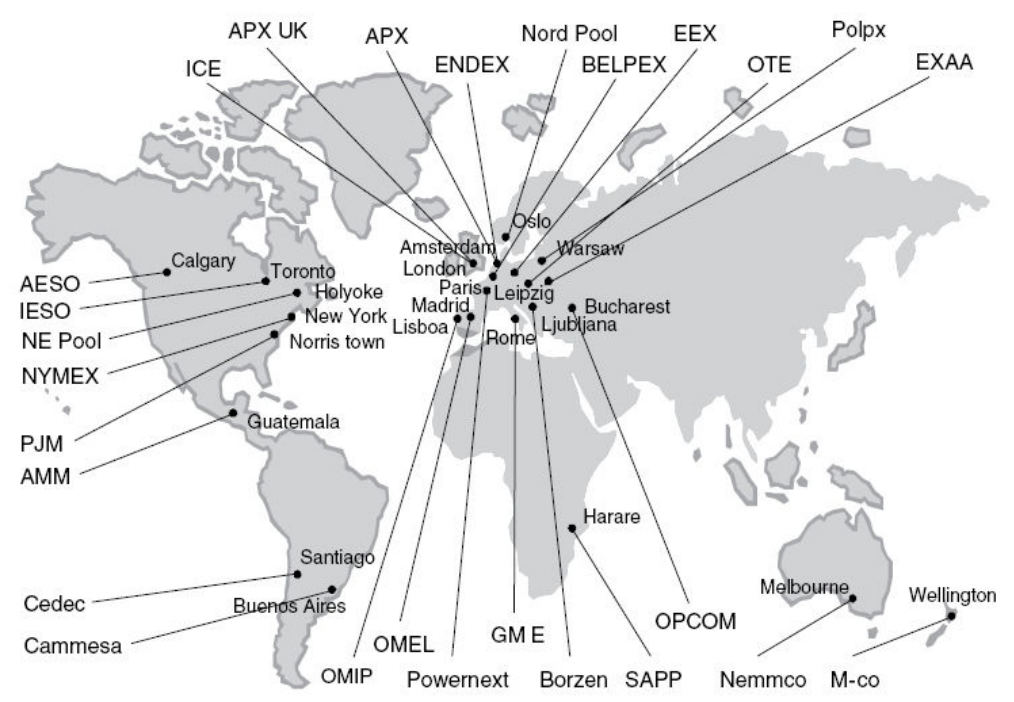

\subsection{TOP ENERGY MARKETS OF THE WORLD REGIONS}

Development of derivatives markets is proportional with development levels of countries and markets deregulation, liberalization and liquidity. Although, the great majority of energy reserves are based in Asia, the world's main advanced energy markets are located in North America and Europe. Further in this part we will consider Chicago Mercantile Exchange Group, NYMEX and Chicago Climate Exchange from North America; NordPool and European Energy Exchange from Europe; Tokyo Commodity Exchange and Singapore Exchange from Asia region; and Intercontinental Exchange mainly based in Europe, but successfully operating in all three regions.

\subsubsection{CME Group}

CME Group is the world's largest and most diverse derivatives exchange. Building on the heritage of CME, CBOT and NYMEX, CME Group serves the risk management needs of customers around the globe. As an international marketplace, CME Group brings buyers and sellers together on the CME Globex electronic trading 
platform and on trading floors in Chicago and New York. After the acquisition of Nymex in 2008, the CME group as a whole remains in first place due to contracts transaction volumes. On a combined basis, CME group had 3.28 billion contracts traded in 2008, versus just 2.87 billion at the Korean Exchange, the 2007 leader. Within CME, legacy CBOT trading was down 6.7\%, legacy CME was up 6.6\%, and legacy Nymex was up $19.8 \%{ }^{154}$ In other words, it was the energy products traded and cleared by Nymex that did most of the pulling last year for the CME train.

By acting as the buyer to every seller and the seller to every buyer, CME Clearing virtually eliminates counterparty credit risk. CME Clearing also offers $\$ 8$ billion in financial safeguards to help mitigate systemic risk, providing the security and confidence market participants need to operate, invest and grow. CME Group offers the widest range of benchmark products available across all major asset classes, including futures and options based on interest rates, equity indexes, foreign exchange, energy, agricultural commodities, metals, and alternative investment products such as weather and real estate. ${ }^{155}$

\subsubsection{New York Mercantile Exchange}

NYMEX, the world's largest regulated energy futures exchange, started life in 1872 as the Butter and Cheese Exchange of New York before being renamed 10 years later. Now, there are crude oil, gasoline, heating fuel, natural gas, coal, electricity and propane futures and options contracts traded on the exchanges. The main oil derivative product of NYMEX is West Texas Intermediate (WTI) light sweet oil futures contract. Table 3.3 gives a short description of this contract.

The NYMEX in making a futures market for natural gas has its main contract, at the Henry Hub, in Louisiana because of the hub's central locality and easy accessibility. In Henry Hub futures, minimum contract unit is 10,000 million British

\footnotetext{
${ }^{154}$ Burghardt and Acworth, 2009, p.23

155 http://www.cmegroup.com
} 
thermal units (MMBTU) and maximum daily price fluctuations are around $\$ 3.00$ per MMBTU (\$30,000 per contract) for all months. ${ }^{156}$

Table 3.3. WTI light sweet crude oil futures contract specifications.

\begin{tabular}{|l|l|}
\hline Product Symbol & CL \\
\hline Venue & Open Outcry (New York) \\
\hline Hours (New York Time/ET) & Monday - Friday, 9:00 AM to 2:30 PM \\
\hline Contract Unit & 1,000 barrels \\
\hline Price Quotation & U.S. Dollars and Cents per barrel \\
\hline Minimum Fluctuation & \$0.01 per barrel \\
\hline Termination of Trading & $\begin{array}{l}\text { Trading in the current delivery month shall cease } \\
\text { on the third business day prior to the twenty-fifth } \\
\text { calendar day of the month preceding the delivery } \\
\text { month. }\end{array}$ \\
\hline Settlement Type & Physical \\
\hline Delivery & $\begin{array}{l}\text { Delivery shall be made F.O.B. at any pipeline or } \\
\text { storage facility in Cushing, Oklahoma with } \\
\text { pipeline access to TEPPCO, Cushing storage or } \\
\text { Equilon Pipeline Company LLC Cushing storage. }\end{array}$ \\
\hline Delivery Period & $\begin{array}{l}\text { Delivery shall take place no earlier than the first } \\
\text { calendar day of the delivery month and no later } \\
\text { than the last calendar day of the delivery month. }\end{array}$ \\
\hline
\end{tabular}

Source: http://www.nymex.com

In response to dramatic changes in both electric and coal industry practices, NYMEX began trading Central Appalachian Coal Futures (CAPP) in July 12, 2001. Coal futures for the months of the current year plus the months in the next two calendar years are traded at NYMEX. CAPP coal futures are a benchmark for coal prices in the United States. Delivery for these contracts is made due to FOB buyer's barge at seller's delivery facility on the Ohio and Big Sandy River District. The specified energy content is $12000 \mathrm{Btu} /$ pound with a sulphur content of less than $1 \%{ }^{157}$

NYMEX provides financially settled monthly futures contracts for peakload and offpeakload electricity transactions based on the daily floating price for each day of the month at the PJM western hub. The underlying price of these monthly futures is the arithmetic average of the PJM western hub real-time locational marginal price (LMP) for the peak and off-peak hours of each day provided by PJM Interconnection LLC. The PJM western hub consists of 111 delivery points, primarily on the Pennsylvania Electric

\footnotetext{
${ }^{156}$ Freedenthal, 2007, p.564

${ }^{157}$ Burger, 2007, p.22
} 
Co and the Potomac Electric Co utility transmission systems. There are monthly futures contracts for the current year plus the next five calendar years. A new calendar year will be added following the termination of trading in the December contract of the current year. Further trading products are options on the PJM monthly futures contracts. ${ }^{158}$

\subsubsection{Chicago Climate Exchange}

Chicago Climate Exchange (CCX) is North America's only voluntary, legally binding greenhouse gas (GHG) reduction and trading system for emission sources and offset projects in North America and Brazil. CCX employs independent verification, includes six greenhouse gases, and has been trading greenhouse gas emission allowances since 2003. The companies joining the exchange commit to reducing their aggregate emissions by $6 \%$ by 2010 . To date the exchange has more than 350 members ranging from corporations like Ford, DuPont, and Motorola, to state and municipalities such as Oakland and Chicago, to educational institutions such as University of California, San Diego, Tufts University, Michigan State University and University of Minnesota, to farmers and their organizations, such as the National Farmers Union and the Iowa Farm Bureau.

$\mathrm{CCX}$ has an aggregate baseline of 226 million metric tons of $\mathrm{CO}_{2}$ equivalent, which is equal to the United Kingdom's annual allocation under the EU ETS. This would make the CCX market comparable to one of the larger countries in the $\mathrm{EU} \mathrm{CO}_{2}$ market, or $4 \%$ of U.S. annual GHG emissions.

CCX has two underlying exchanges - Chicago Climate Futures Exchange (CCFE) and European Climate Exchange (ECX). From 2006, $\mathrm{SO}_{2}$ futures agreement, Sulphur Financial Instrument (SFI), is traded on CCFI. The European Climate Exchange (ECX) was launched by CCX in 2005, and is now the leading exchange operating in the European Union Emissions Trading Scheme. ECX manages the product development and marketing for ECX Carbon Financial Instruments (ECX CFIs) futures and options contracts, listed and admitted to trading on the ICE Futures electronic platform.

${ }^{158}$ Burger, 2007, p.36 
Graph 3.1. Monthly futures and options trading volume in CCFE (06.2008 - 06.2009)

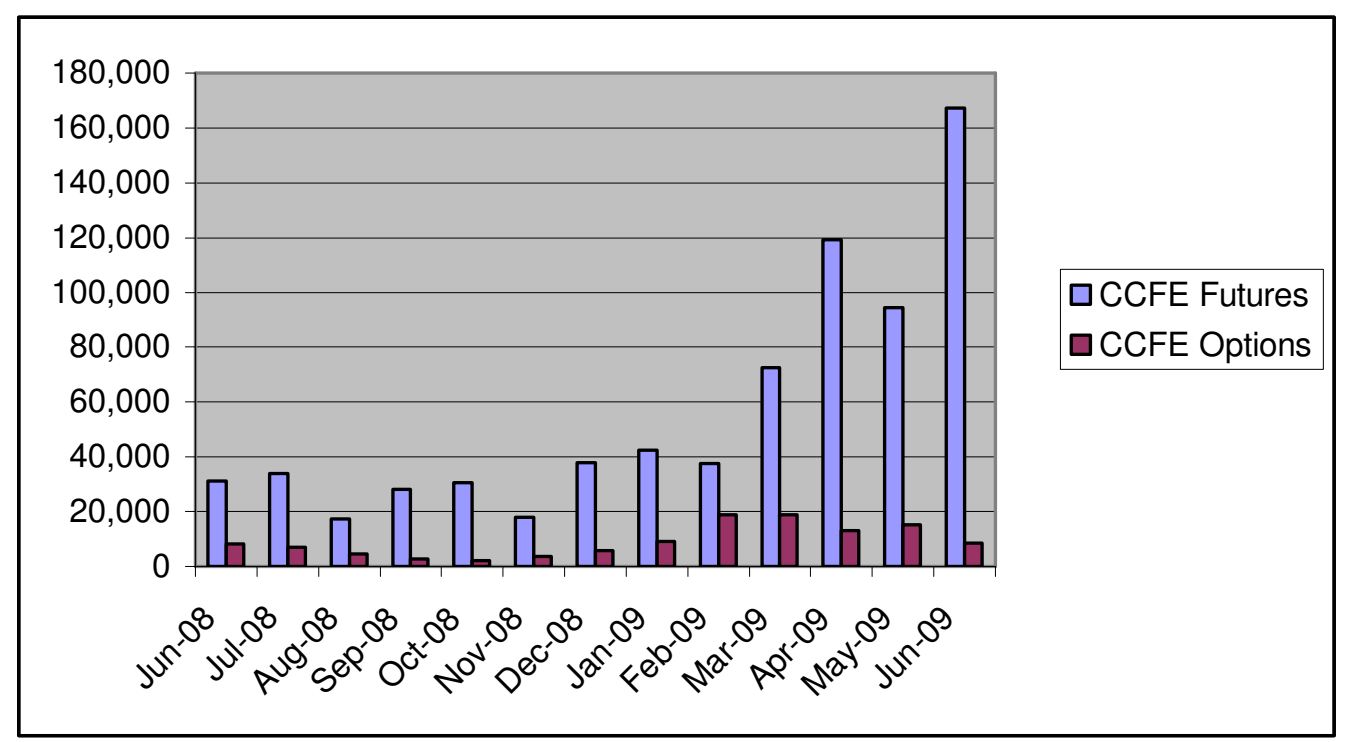

Source: http://www.chicagoclimateexchange.com.

The Trading Platform of CCX is a marketplace for executing trades among Registry Account Holders. For instance, National Farmers Union's Carbon Credit Program is a multi-state program that allows farmers and landowners to earn income by storing carbon in their soil through no-till crop production and longterm grass seeding practices. Farmers Union has earned approval from the Chicago Climate Exchange to aggregate carbon credits. Farmers Union is enrolling producer areas of carbon into blocks of credits that will be traded on the Exchange, much like other agricultural commodities are traded.

\subsubsection{Intercontinental Exchange}

Intercontinental Exchange (ICE) was established in May 2000, with its founding shareholders representing some of the world's largest energy traders. The company's stated mission was to transform OTC trading by providing an open, accessible, multi-dealer, around-the-clock electronic energy exchange. The new exchange offered the trading community better price transparency, more efficiency, greater liquidity and lower costs than manual trading. 
In June 2001, ICE expanded its business into futures trading by acquiring the International Petroleum Exchange (IPE), now ICE Futures Europe, which operated Europe's leading open-outcry energy futures exchange. Since 2003, ICE has partnered with the Chicago Climate Exchange (CCX) to host its electronic marketplaces. In April 2005, the entire ICE portfolio of energy futures became fully electronic.

The company expanded rapidly in 2007, acquiring the New York Board of Trade (NYBOT), ChemConnect (a chemical commodity market), and the Winnipeg Commodity Exchange. In March 2007 ICE made an unsuccessful \$9.9 billion bid for the Chicago Board of Trade, which was instead acquired by the Chicago Mercantile Exchange. In January 2008 ICE partnered with TSX Group's Natural Gas Exchange, expanding their offering to clearing and settlement services for physical OTC natural gas contracts.

Intercontinental Exchange operates Internet-based marketplaces which trade futures and over-the-counter (OTC) energy and commodity contracts as well as derivative financial products. The ICE trades many oil, gas and power OTC contracts in North America and Europe, but its primary growth in recent years has been in Asia. ${ }^{159}$ The actively traded contracts in ICE are based on products such as Brent Crude Oil, West Texas Intermediate (WTI) Crude Oil, Middle East Sour Crude Oil, Emissions (ECX CFI), Gas Oil, Heating Oil, RBOB Gasoline, Coal, U.K. Electricity and U.K. Natural Gas. ${ }^{160}$

The most liquid futures exchange for natural gas in Europe is ICE. The main specifications of ICE UK Natural Gas Futures are trading period of 10-12 consecutive months, 11-12 quarters and six seasons and a contract size in five lots of 1000 therms of natural gas per day. ${ }^{161}$ Price quotation of this contract is in GB pence per therm and the last trading day is within two business days prior to the first calendar day of the delivery month, quarter or season.

\footnotetext{
${ }^{159}$ Fusaro, The Energy Markets, 2004, p.7

${ }^{160}$ Pure Energy; IntercontinentalExchange, 2005, p.6

${ }^{161}$ Burger, 2007, p.13
} 
Graph 3.2. Yearly trading volume of some energy futures products in ICE (2005-2009)

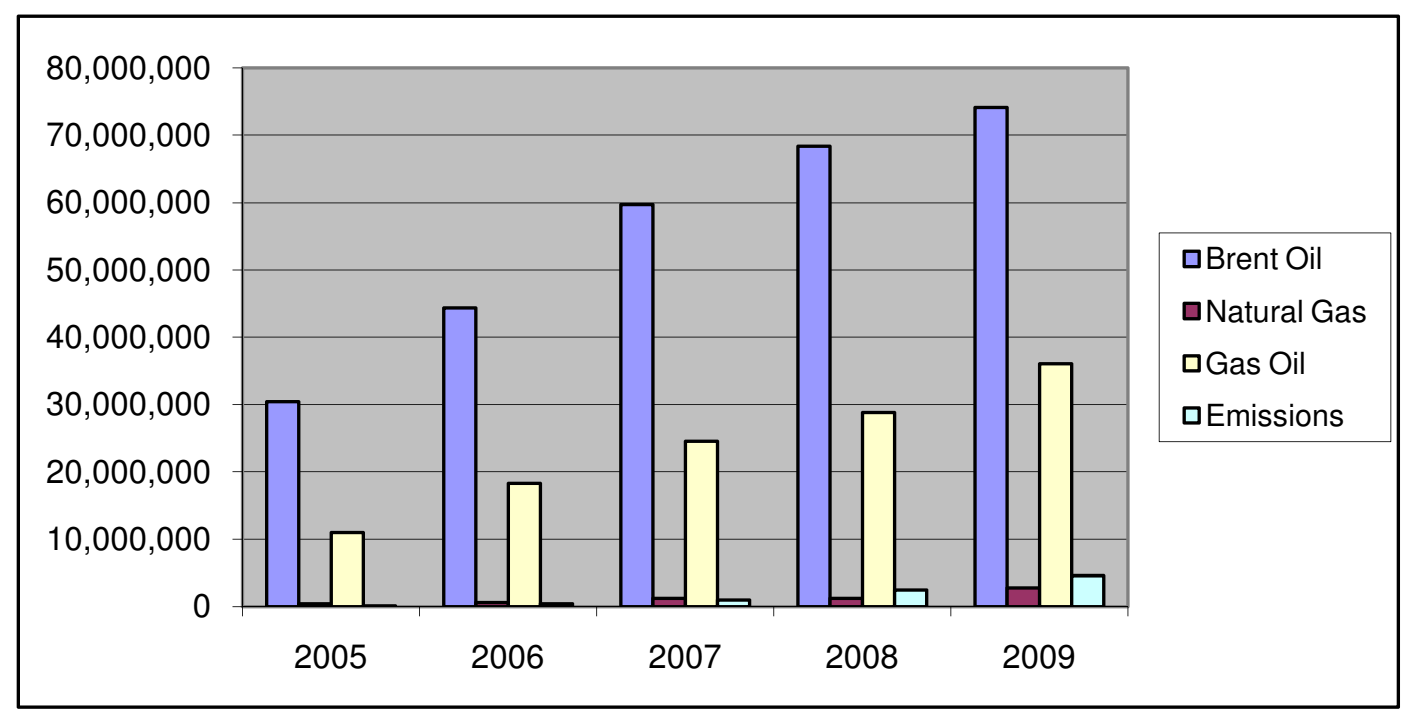

Source: http://www.theice.com

The Intercontinental Exchange offers Rotterdam coal futures contracts, which are financially settled, based on delivery to Rotterdam in the Netherlands. It is cash settled against API\#2. ICE also offers Richards Bay coal futures, financially settled against API\#4. Both are offered for six consecutive months, six consecutive quarters, five consecutive seasons and two consecutive calendar years. ${ }^{162}$

ICE electricity futures contracts are deliverable contracts where each clearing member with a position open at cessation of trading for a contract month is obliged to make or take delivery of electricity to or from National Grid Transco, United Kingdom. ICE offers UK baseload and peakload electricity futures for the next 12 months, six quarters and four seasons. ${ }^{163}$

\subsubsection{NordPool Exchange}

Nord Pool is a multinational exchange for trading electricity in Northern Europe. It was founded in 1993 initially as the Norwegian market for physical contracts, as a result of the deregulation of the Norwegian electricity market in 1991. In 1996 the joint Norwegian-Swedish power exchange commenced, the world's first multinational

\footnotetext{
${ }^{162}$ Burger, 2007, p.22

${ }^{163}$ IBIT, p. 36
} 
exchange for trade in power contracts. Subsequently Finland and Denmark joined the Nordic power exchange market area. In 2006 the traded volume in the physical market (Elspot) was 250TWh and there were 294 registered participants. The volume in the financial market was 766TWh and together with the clearing volume of the OTC market there is a total volume of $2160 \mathrm{TWh}$ with a value of approximately 79 billion Euros. This total trading volume exceeds by far the generation of approximately $370 \mathrm{TWh}$ in Norway, Sweden, Finland and Denmark.

There are three product groups at Nord Pool - physical market, financial market and clearing service. The physical spot market is divided into Elspot and Elbas. Nordic market participants trade power contracts for next day physical delivery at the Elspot market. This day ahead trading is based on an auction trade system. Bids for purchase and sale of power contracts of one-hour duration cover all 24 hours of the next day. ${ }^{164}$ After the publication of the Elspot results there is a physical intra-day market called Elbas for the areas Eastern Denmark, Finland and Sweden. The Elbas market is based on hourly contracts and provides continuous power trading 24 hours a day, up to one hour prior to delivery. ${ }^{165}$

The Nord Pool offers a liquid financial market for price hedging and risk management with a time horizon of up to four years. The market consists of futures, forwards, options and contracts for differences. Futures contracts consist of standardised day and week contracts. The settlement of futures contracts involves a daily marked-to-market settlement and a final spot reference cash settlement after the contract reaches its due date. To overcome potential price differential risk Nord Pool offers a forward contract product named Contracts for Difference. The liquidity of these contracts is sometimes insufficient. Options contracts traded at Nord Pool use standard forwards as the underlying contract. ${ }^{166}$ The option contracts are European style, so they can only be exercised at the exercise date. Options with new strike prices are automatically generated to reflect price movements of the underlying forward instrument.

\footnotetext{
${ }^{164}$ Lucia, Julio J. and Schwartz, Eduardo S.; Electricity Prices and Power Derivatives: Evidence From The Nordic Power Exchange, Anderson Graduate School of Management, No:1061, 2001, p.4-5

${ }^{165}$ Burger, 2007, p.34

${ }^{166}$ IBIT, p.35
} 
Alongside with standardized contracts Nord Pool Clearing also clears contracts traded in the bilateral financial markets that are registered for clearing. To be accepted for clearing a bilateral market electricity contract must conform to the standardised products traded at Nord Pool. This clearing service reduces clearing members' counterparty risk.

\subsubsection{European Energy Exchange}

The European Energy Exchange (EEX) is located in Leipzig, Germany, and is the leading exchange for electricity in Central Europe. Preceding companies were Leipzig Power Exchange started in 2000 and European Energy Exchange started in 2001. Both exchanges and their supporting associations merged in 2002. At the EEX the product groups are - power spot market, power futures and options and coal futures and EU emission allowances. ${ }^{167}$

Futures contracts with financial and physical settlement are traded at the EEX. The underlying of the financially settled futures contracts is the EEX spot market index Phelix. The settlement of futures contracts involves a daily marked-to-market settlement. Yearly and quarterly futures are fulfilled by cascading. EEX offers European-style options, i.e. the options can only be exercised on the last day of trading. The underlyings are the financially settled futures. More specifically, options on the respective next five baseload monthly futures, the respective next six baseload quarterly futures and the respective next three baseload yearly futures can be traded. The liquidity of the EEX options market has so far been very low. ${ }^{168}$

In 2008 the trading of electricity in EEX amounted to 1319 TWh (terawatt hours), an increase of $3.6 \%$ over the previous year. The physical spot market was 154 TWh and in the futures market, including OTC clearing, was $1165 \mathrm{TWh}$. The traded volume clearly exceeds the total consumption in Germany of approximately 540 TWh. ${ }^{169}$

${ }^{167}$ Burger, 2007, p.35

${ }^{168}$ IBIT, p.36

${ }^{169} \mathrm{http}: / /$ www.eex.com 
EEX offers a well-accepted clearing service for OTC trades. The volume of OTC clearing is comparable to the volume of the traded futures. OTC transactions corresponding to available EEX futures or options can be registered by means of a socalled EFP (Exchange Futures for Physical) trade for OTC clearing. ${ }^{170}$

\subsubsection{Tokyo Commodity Exchange}

Tokyo Commodity Exchange (TOCOM) is a non-profit organization, and regulates trading of futures contracts and option products of all commodities in Japan. TOCOM was formed in 1984 by a merger of the Tokyo Gold Exchange, the Tokyo Rubber Exchange, and the Tokyo Textile Exchange. TOCOM is the biggest futures exchange in Japan for such products as gasoline, kerosene, platinum and rubber. ${ }^{171}$ In the last decade, TOCOM has made a great progress with its Middle East crude oil and refinery products futures contracts. But the range of market participants and liquidity is still a long way away from that seen on the IPE and the NYMEX and as a consequence the last years exposed a considerable market decline.

\section{Graph 3.3. Yearly trading volume of energy products in TOCOM (1999-2008)}

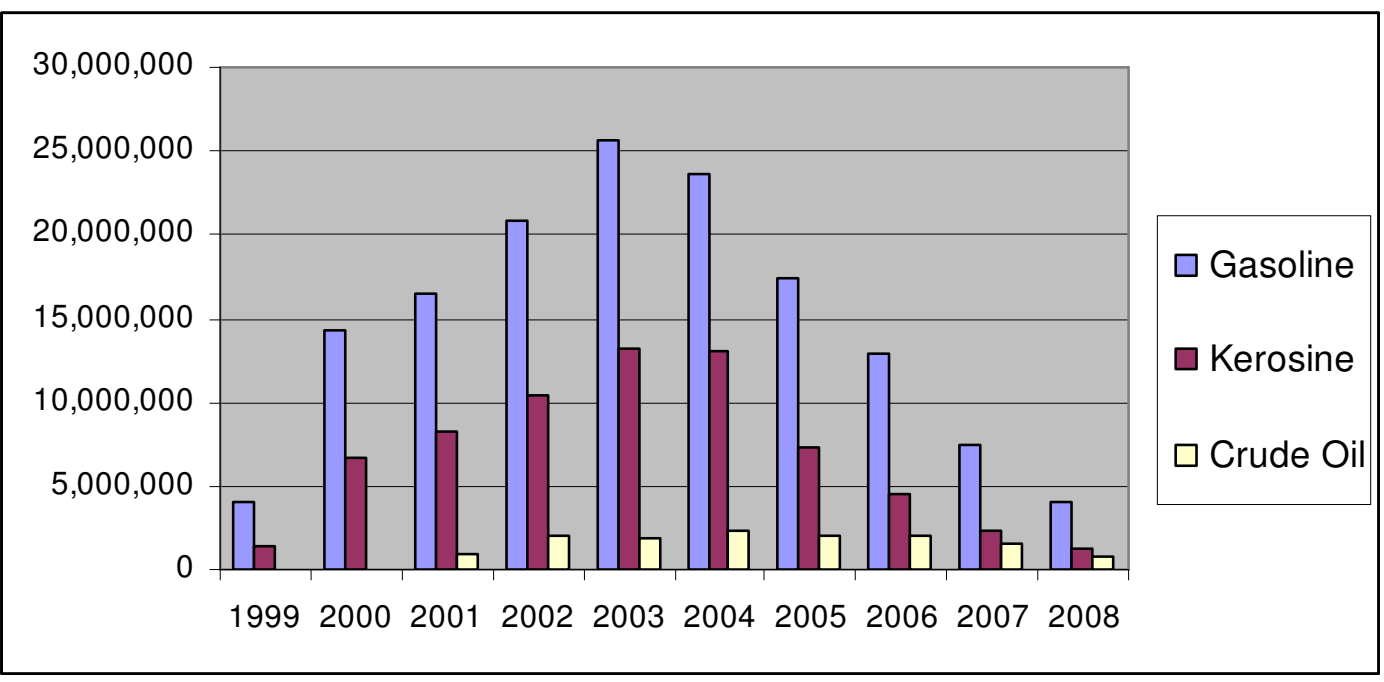

Source: http://www.tocom.or.jp

\footnotetext{
${ }^{170}$ Burger, 2007, p.36

${ }^{171}$ Burgin, Daniel; Implementing Pure FIX to one of Japan's Most Trading Bussisnes Commodities, FIXGlobal, 2004, Vol. 1, Issue 4, p.63
} 
In 2002, Singapore Exchange launched the TOCOM Middle East crude contract in Singapore but in US dollars and barrels instead of yen and kilolitres. Rather than trying to create a brand new contract, an interesting approach by SGX has been to create a forex hybrid of the TOCOM Middle East crude contract. Since traders should be able to offset margin calls between the SGX contract (in US\$ per barrel) and the TOCOM contract (yen/kilolitres) either at the exchange/clearing house level or at their clearing broker level, there are interesting opportunities to trade the forex arbitrage between the two contracts, and also to trade the arbitrage between TOCOM and SGX contract with the OTC Dubai/Oman, WTI Crude Futures on NYMEX and/or Brent Futures on the IPE. There is already some speculative trading between the TOCOM Middle East crude contract and the Dubai/Oman OTC swaps arbitrage and also against the WTI NYMEX Futures. ${ }^{172}$

\subsubsection{Singapore Exchange}

SGX was formed on December 1, 1999, following the merger of two established and well-respected financial institutions - the Stock Exchange of Singapore (SES) and the Singapore International Monetary Exchange (SIMEX). It is the AsiaPacific's first demutualised and integrated securities and derivatives exchange.

In 2008 SGX posted a profit of over \$200 million which represents more than double growth of 2007 corresponding period. The strong results were achieved on the back of robust securities trading driven by high volatility and liquidity in the markets. Its Futures and Options market saw also another record year in 2007. SGX's derivatives volume exceeded 44 million contracts, surpassing its previous annual record volume in 2006 by $21 \% .^{173}$

The Singapore market is oriented to cargo size shipments, so individual transactions, sometimes referred to as 'clips', are quite large compared to an IPE Brent Futures contract which is a minimum trade of 1,000 barrels. Almost everything in the Singapore market is sold in 50,000 barrel clips and the typical cargo size is 150,000 barrels. High Sulfur Fuel Oil used for ships bunkering is the only exception. Both 180

\footnotetext{
172 James, 2003, p.73

${ }^{173} \mathrm{http} / / /$ www.sgx.com
} 
CST (the main OTC Fuel Oil swap market) and 380 CST fuel oil is traded in 5,000 MT but it can also be traded in clips as small as 1,000 MT units. ${ }^{174}$ In Singapore, OTC swaps transactions were approximately 300,000,000 barrels per month on average for the months up to October 2002 according to a survey conducted by the Energy College, London. To put this into perspective in terms of growth, in 1998, the Singapore swaps market was estimated to be around 150,000,000 barrels per month.

SGX also offers a clearing service called SGX AsiaClear. AsiaClear provides the clearing and netting platform for OTC oil, commodity, and freight derivative deals. By June of year 2008 the volume had tripled to $\$ 3.8$ billion year over year and the number of trading counterparty accounts had reached $221 .^{175}$

\subsection{ENERGY E-TARDING}

The oil and gas industry has been gradually using energy risk management tools to manage its financial risks over the past two decades. The unprecedented price volatility in oil, gas, and electric power markets experienced since late 1998 are accelerating industry adoption of both financial instruments and Internet energy trading. While liquidity on the Internet today remains low, the movement to Internet trading will create its own liquidity and force the OTC paper-based markets for oil, gas, and power to migrate to the Web. The end of the energy monopoly has already begun to produce competition in some areas and new ways for getting the commodity to the customer. However, creating the distribution channel that allows multiple companies to participate remains an unsolved technical challenge. ${ }^{176}$

Electronic index construction such as Dow Jones electricity or bandwidth indexes coupled with screen trading has now catalyzed the global energy industry into the Internet age. The proliferation of electronic brokering and trading platforms that are emerging today will continue to change the face of energy trading.

\footnotetext{
${ }^{174}$ James, 2003, p.73

${ }^{175}$ Ronalds, Nick; Asia on the Horizin: A Tour of Derivatives Markets Across the Asia-Pasific Region, Futures Industry, September-October, 2008, p.28

${ }^{176}$ McGowan, John J.; E-Enabled Energy Services:B2B in the Energy Sector, Energy User News, February, 2001, p.23-24.
} 


\subsubsection{North American Electronic Energy Platforms}

Today, one clear electronic trading winner is the Intercontinental Exchange, backed by the major energy companies, gas and electric utilities and investment banks. ICE launched all its energy verticals by October 2000. These included crude oil, petroleum products, natural gas, and electricity. The major players behind this electronic trade are very active in oil, gas, and power markets on both the physical and financial sides. The backers include American Electric Power, BP, Shell, Duke, Aquila Energy, Morgan Stanley, Goldman Sachs, El Paso Energy, Reliant Energy, Southern Energy, Deutsche Bank, Totalfina Elf, and SG Investment Banking. The only piece missing for total oil, gas, and power dominance by ICE are the participation of the major European gas and electric utilities, such as Electricite de France, Germany's RWE, Italy's ENEL, and Spain's Endesa. ${ }^{177}$ Market liquidity is growing rapidly even in niche markets like jet fuel hedging. Its acquisition of the International Petroleum Exchange further solidified its hold on electronic trading dominance. ICE extends its energy trading platform to the emerging commodity markets of coal, weather, emissions and bandwidth.

NYMEX has had an after-hours trading system for its energy futures contracts for the past decade called ACCESS. The exchange has launched a web-enabled ACCESS in September $2001^{178}$, which has become more important due to the World Trade Center disaster and the need to trade energy futures electronically. However, NYMEX had not extended electronic trading to floor trading hours. Because the exchange members do not want to cannibalize their existing trading floor business and its highly liquid and successful oil and natural gas futures contracts, which continue to grow each year. ${ }^{179}$ Thus, they have decided to launch OTC trading platform, which puts it in direct competition with ICE and other OTC Internet trading platforms.

There are some other niche markets servers, too. Enron's once highly successful business model has been emulated by Dynegy's dynegydirect which is

\footnotetext{
${ }^{177}$ Fusaro, Peter C.; Energy Convergence: The Beginning of The Multi-Commodity Market, New York: John Wiley \& Sons, Inc., 2002, p.226

${ }^{178}$ http://www.nymex.com

${ }_{179}$ Fusaro, Energy Convergence, 2002, p.227
} 
offering more than 150 products in North American gas, power, and natural gas liquids markets. Dynegyconnect has been launched as a means to offer increased connectivity to expand networks and add Internet access to their service portfolios. The oldest of all electronic trading platforms with the launch of Chalkboard for oil trading, Altra Energy Technologies has three acquisition modes - TransEnergy Management, Quicktrade and Energy Imperium. The other e-platform, TradeSpark has a different mix of partners than ICE. Williams, Dynegy, Coral Energy, Dominion, Koch, TXU, Entergy, and broker Cantor Fitzgerald's eSpeed may have a chance at some liquidity. These well-capitalized partners may offer another alternative to the dominance of the Intercontinental Exchange.

\subsubsection{European Electronic Energy Platforms}

Presently, European Internet platforms are still poorly defined. The need for separate power exchanges for almost each country in the EU does not demonstrate a willingness to move away from nationalism. The Internet is borderless. The many platforms are highly parochial. There are the Amsterdam Power Exchange, the European Energy Exchange, the Polish Power Exchange, the Austrian Power Exchange, and up to four electricity verticals in the United Kingdom. The only successful platform has been Nord Pool in Scandinavia which has worked successfully since 1993 due to the nature of the hydropower/nuclear power markets in Norway, Sweden, and Finland. It is a small, successful niche market.

\subsubsection{Asian Electronic Energy Platforms}

The Asian Internet energy markets are evolving more slowly. While Platts Global 190 trades oil electronically, it considerably lacks trade interest. There is Open Spec Naphtha (e-OSN.com) in the East Asian markets that has an active and liquid forward OTC market for more than a decade. E-OSN.com acts as broker to all market participants. However, the site is a niche market play.

The Tokyo Commodity Exchange energy contracts for gasoline is gaining some liquidity but the contract volume in kiloliters is quite small. ICE may become the dominant player in Asia as well as Europe and North America. One of the obstacles in 
Asian market development has been that Asian Internet growth lags worldwide usage but should accelerate over the next several years. In fact India's National Stock Exchange (NSE) is the world's largest electronic exchange for equity trading with 235 million transactions on derivative market. ${ }^{180}$

\subsection{ENERGY HEDGE FUNDS}

Hedge funds have become, and are likely to remain, an important element of modern financial markets. Most investment banks and traditional asset management houses have announced the launch of in-house hedge funds. Commercial banks are also setting up funds of hedge funds. Hedge funds can no longer be seen as a homogeneous asset class. There are now more than 6000 hedge funds and 3000 funds of hedge funds active in several asset classes, sectors or regions. These funds utilize a variety of trading and investment strategies. Within the same investment category, managers differ in the leverage they use, the concentration they apply and the hedging policies they employ. ${ }^{181}$

In the volatile and rapidly evolving world of energy trading, hedge funds are becoming increasingly significant market participants. There have been a lot of assumptions about them over the past decade, most of it negative. Outsized leverage, secrecy, lack of regulatory oversight and spectacular market losses that are said to characterize hedge funds. Nevertheless, each of these alleged negatives can have an associated positive for a potential over-the-counter trading counterparty. For example, a hedge fund taking a huge bet offers its counterparties market liquidity. Although as private entities they do not file public reports of their financial condition, hedge funds often have very precise knowledge of their current finances. Many hedge funds have sophisticated quantitative support and can offer highly customized products in addition to liquidity. ${ }^{182}$

Hedge Funds are un-regulated private investment funds that seek to profit from nontraditional opportunities using alternative investment strategies. As a result of their

\footnotetext{
${ }^{180}$ Ronalds, 2008, p.24

${ }^{181}$ Francois-Serge Lhabitant, Handbook of Hedge Funds, Chichester: John Wiley \& Sons Ltd, 2007, p.2

${ }^{182}$ Weinstein, Jeremy; Energy Trading Contracting with Hedge Funds, The 58th Annual Oil \& Gas Law Conference, 2007, p.1-2
} 
expertise in other markets, hedge funds are attracted by the volatility in energy markets and see a speculative trading opportunity. ${ }^{183}$ Unregulated and largely secretive hedge funds trade crude oil, petroleum products, natural gas, physical and financial power, coal, emissions and renewable energy. They are also active in distressed generation and other energy industry physical assets and both equity and debt for energy companies. ${ }^{184}$

A combination of price volatility and available energy trading in high risk exposure creates the opportunity for hedge funds. With over 100 hedge funds already playing or set to play in energy commodities, they are primed to bring more risk capital to energy markets. They also bring sophistication, liquidity, the risk culture and trading acumen to bear on energy markets and have access to readily available experienced trading resources. While new hedge funds are being created specifically for the energy trading opportunity, existing larger hedge funds are also planning to enter energy markets. ${ }^{185}$ In 2005 energy hedge funds held $\$ 50$ billion or $52 \%$ of overall capital of world hedge funds industry.

Today, the energy hedge fund arena is ramping up due to the need for higher returns for hedge fund investors. Energy hedge funds are still only about $5 \%$ of the hedge fund universe, but continue to grow in North America and Europe predominantly. More hedge funds and funds of funds are in formation as the energy bull market will continue with rocky price spikes and collapses.

\footnotetext{
${ }^{183}$ Vasey, Gary M.; Hedge Funds, Attracted By Energy Commodity Price Volatility, Set to Enter Energy Trading, UtilityPoint, 2004, p.2

${ }^{184}$ Fusaro, Peter and Vasey, Gary M.; Energy Hedge Funs: Why Have They Appeared Now?, Commodity Now, 2004, December, p. 1

${ }^{185}$ Fusaro, Peter; The Next Wave Energy Trading, PRMIA, 2004,Vol.3, Issue 7, July:4-5, p.4
} 


\section{ENERGY MARKETS AND APPLICABILITY OF ENERGY DERIVATIVES IN TURKEY}

In this part of the research the historical growth and the recent condition of Turkish energy markets will be investigated. Due to present position of derivative markets in Turkey the applicability of energy derivatives here will be evaluated. The dependence of futures oil prices of spot oil prices will be determined with the SPSS application of correlation and linear regression analyses in the end of this part.

\subsection{TURKEY'S ENERGY PROFILE}

Affordable and uninterrupted supply of energy sources is of fundamental importance for a country's sustainable economic development. It is directly related to the competitiveness of industries and citizens' economic welfare. Moreover, energy supply security is also closely associated with the national security of a country and no country is capable of dealing with its energy issues on its own. Already the $6^{\text {th }}$ largest economy of Europe and $17^{\text {th }}$ of the world Turkey's energy demand increases at a yearly rate of 6-8\%. Imports are the major portion of Turkey's energy needs. Turkish energy markets were accompanied with large market liberalization actions in the last decade, to provide a more efficient marketplace with strong self-regulating price mechanism. Furthermore, Turkey's strategic location makes it a natural "energy bridge" between the major oil producing areas in the Middle East and Caspian Sea regions on the one hand and consumer markets in Europe on the other hand. In its turn this condition propelled significant energy projects to be realized with Turkey's active participation.

\subsubsection{Primary Energy Markets}

Like close to half of the world's states, Turkey possesses few indigenous sources of energy, importing approximately 80 percent of the energy that it consumes. Turkey produces small amounts of oil and poor quality coal, marginal amounts of natural gas and no nuclear energy at this stage. In April 2006, Ankara announced its decision to establish its first nuclear power station to be built in Sinop, which is intended to become operational in 2012. Turkey produces a robust amount of 
hydroelectricity and has the potential to increase hydroelectric production. In addition, Turkey produces very small amounts of renewable energy sources and is in a position to increase production of wind, geothermal and solar power production, if it promotes the appropriate policies. Turkey's total primary energy supply (TPES) is comprised of: oil $38 \%$; natural gas 23\%; coal 27\%; combustible renewables and wastes $7 \%$. The remainder comes from hydroelectric power, geothermal energy and additional renewable energy sources. ${ }^{186}$

Graph 4.1. Turkey's Total Primary Energy Supply, 1973-2020

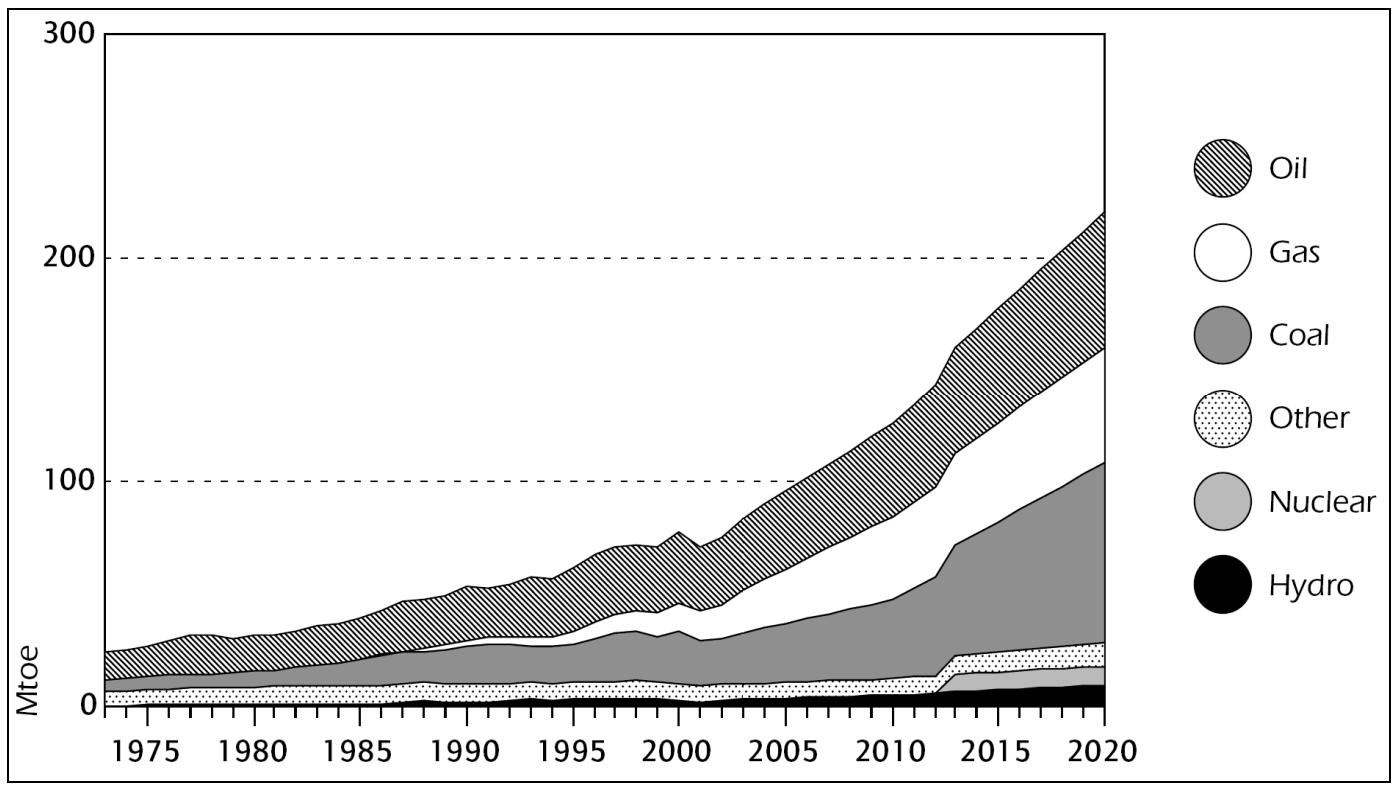

Source: Energy Policies of IEA Countries - Turkey, 2005, p.25

Turkey's oil reserves are relatively small. Oil is produced mainly in the southeast, with a small amount coming from the north-west of the country. Since its peak in 1991, domestic oil production has been declining owing to the depletion of resources. While Turkey produced 3.7 Mt of oil in 1999, production was 2.5 Mt in 2003 and is expected to be decline by almost half by 2010 .

\footnotetext{
${ }^{186}$ Shaffer, Brenda; Turkey's Energy Policies in a Tight Global Energy Market, Insight Turkey, Vol.8, April-June, 2006, p.97
} 
From its 33.3 million tons of current total oil demand, Turkey imported 8.35 million tons of crude oil from Iran, 9.36 million tons from Russia, 3.33 million tons from Saudi Arabia and 0.61 million tons from Libya in 2007. Italy's share in Turkey's total imported crude oil was 0.44 million tons while Syria and Iraq supplied 0.24 million tons and 0.86 million tons respectively. Total crude oil import from Iran, Russia and Saudi Arabia reached 91 percent in 2007. ${ }^{187}$

\section{Graph 4.2. Energy consumption in different sector, 1997 and 2007 (Mtoe)}

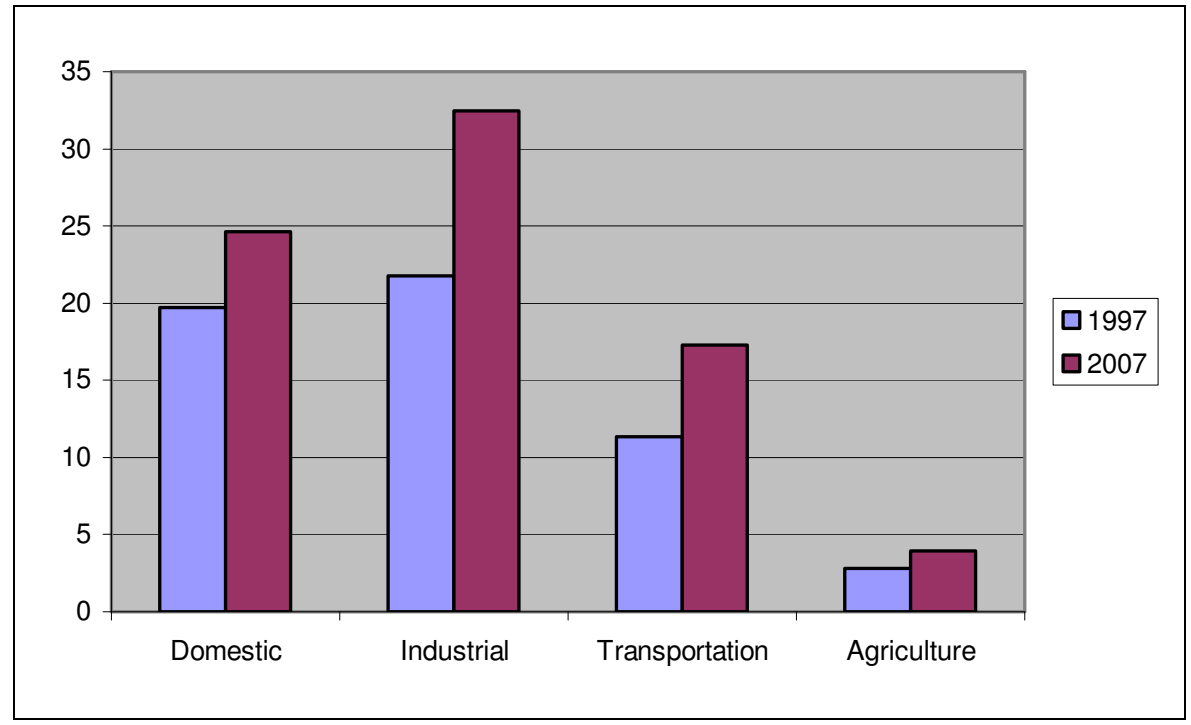

Source: World Energy Council, Energy Report of Turkey - 2008, p.113

Turkey has considerable oil refining capacity, and it is an exporter of refined oil products. If Turkey's energy consumption continues to grow, refining capacity will need to expand in order to meet demand. Turkey sells one third of its refined oil products to OECD states and another third to Middle Eastern countries. ${ }^{188}$

Diversification is a key phenomenon for the Turkish energy policy. More than oil, nowadays natural gas has become more strategic commodity for all producer, consumer and transit countries. Between 1987-1994 Turkey was dependent on Russian gas (western route) 100\%. In 1994 Algeria LNG contract started, following with Nigerian LNG imports in 1999. Iran line was opened in 2001 and two years later the Blue Stream became operational. In July 2007, Azeri gas arrived to Turkey through

\footnotetext{
${ }^{187}$ Turkey's Fuel Market Sales Volume On The Rise, Turkish Daily News (AA), 05.05.2008

${ }^{188}$ Shaffer, 2006, p.99
} 
BTE line. Turkey's dependence shares on natural gas as of 2008 are: Russia $61.80 \%$ (34.41 Western Route, 26.39 Blue Stream); Azerbaijan 12.33\%; Iran 11.07\%; Algeria $\% 11.16$ and Nigeria $2.74 \% .^{189}$

In 2007 Turkey imported $38 \mathrm{bcm}$ gas. Gas demand according to BOTAŞ will be $44,5 \mathrm{bcm}$ in $2010 ; 56,9 \mathrm{bcm}$ in $2015 ; 66,6 \mathrm{bcm}$ in $2020 ; 76,4 \mathrm{bcm}$ in 2030 . Consumption in 2008 was $36.8 \mathrm{bcm}$. Today, Turkey possesses no significant natural gas storage facilities and its current capacity is below the NATO standard of three months supply.

Graph 4.3. Energy Production by Source in Turkey, 1973-2020

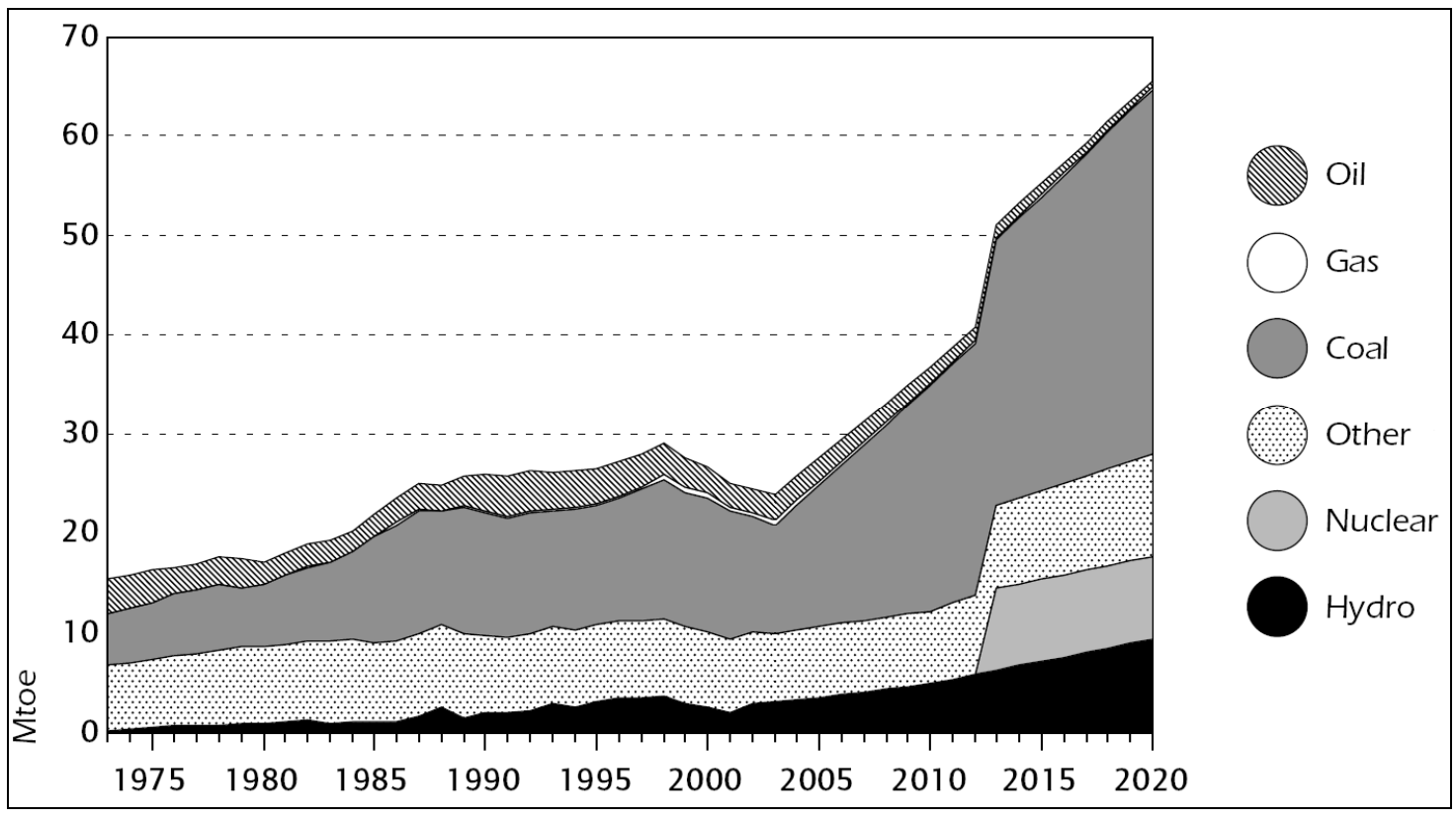

Source: Energy Policies of IEA Countries - Turkey, 2005, p.26

Coal, particularly lignite, is Turkey's most important domestic energy source. The country produces hard coal and lignite. The government is launching a programme to study the country's coal potential in addition to the current process reserves. Three main companies operating in the coal sector are the state-owned companies: Turkish Hard Coal Enterprise (TTK), Turkish Coal Enterprises (TKI) and the Electricity Generation Company (EÜAŞ). TTK has a de facto monopoly in hard coal production,

${ }^{189}$ http://www.turkstat.gov.tr, Turkish Statistical Institute, 20.12.2009 
processing and distribution. TKI produces more than half of all lignite (55\% in 2003), private companies produce around $10 \%$ and the rest is produced by EUAS, for its power plants. ${ }^{190}$

Total coal demand increased by 33\% between 1990 and 2003 to 22.5 Mtoe. Its share of the TPES was $27 \%$. Final consumption of coal grew by $77 \%$ over the period, reaching 13.4 Mtoe. The government expects coal demand to grow by $56 \%$ by 2010 and to threefold between 2010 and 2020 driven by an increasing use of lignite in power generation.

Lignite is found in almost all regions of the country. The most important reserves are in the Afşin-Elbistan, Muğla, Soma, Tunçbilek, Seyitömer, Beypazarı and Sivas regions. About $90 \%$ of the lignite is produced through opencast mining and $10 \%$ by underground mining. Proven lignite reserves totalled about 8.4 billion tones. Nearly $68 \%$ of Turkish reserves have low calorific value.

Hard coal is found and mined in only one location, the Zonguldak coal basin on the north-west Black Sea coast. The geological reserves of the basin, calculated down to 1200 metres, are about $1344 \mathrm{Mt}$ of which 40\% (550 Mt) are proven reserves.

Turkey's electricity market of Turkey is increasing in steady rate. Annual electricity demand growth rate became 6.6\% between 1995 and 2004 and is projected as $8.5 \%$ for the decade between 2005-2015. The electricity consumption, which peaked to 150 billion $\mathrm{kWh}$ in 2004, is envisaged to increase almost four-fold by 2020 reaching to 499 billion $\mathrm{kWh}$. This requires installed capacity to increase more than two fold - from recent $40,000 \mathrm{MW}$ to $96,000 \mathrm{MW}$ by 2020 . These figures are well above the EU average and combined with the low per capita consumption levels, are an indication of the vitality of the sector. ${ }^{191}$

In 2006, Turkey took major steps to synchronize its electricity grid with the European grid (UCTE) and has electricity interconnections with most neighboring countries. Turkey's electric system is not yet synchronously connected with neighboring

\footnotetext{
${ }^{190}$ Energy Review - Turkey, Energy Policies of IEA Countries, 2005, p.89

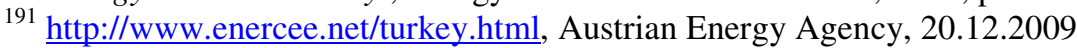


systems, but it is exploring policies to rectify this. In addition, Turkey has taken steps to interconnect its natural gas system with that of neighboring states.

In the past two decades, Turkey has made significant progress in switching from power generation by coal-fired plants to those employing natural gas. Switching to natural gas from oil and coal has been facilitated in a variety of sectors by Turkey's improved natural gas transmission and distribution infrastructure.

The share of fossil fuel for energy generation in the world is about $77 \%$, and this figure reaches $90 \%$ in some countries. The situation is no different in Turkey, and the share of fossil fuels is as high as $90 \%$ in primary energy consumption. Fossil fuels also dominate in electricity generation, for about $60 \%$. From the greenhouse gas emissions point of view, Turkey is not that critical, since, $\mathrm{CO}_{2}$ emissions per capita are only three-quarters of world average. However, in the year 2020, current installed capacity will be tripled and greenhouse gas emissions will increase accordingly. Hence, clean technologies like nuclear and renewable sources will be unavoidable in countries such as Turkey, if greenhouse gas emissions are to be stabilized at given levels, as international agreements and protocols (such as the Kyoto Protocol) require. ${ }^{192}$

\subsubsection{Liberalization and Organization of Energy Markets}

Turkey has embarked on the liberalization of the energy sector in line with the EU directives. The turning point in energy markets occurred in 2001, when two laws were enacted to end the state's monopolies in power and natural gas. This was followed by a series of other laws on the electricity market licenses (2002), oil market (2003) and renewable energy (2005).

The main regulatory power of Turkish energy markets, Energy Market Regulatory Authority (EPDK) was established as the independent regulatory authority for electricity by the Electricity Market Law in February 2001. After the enactment of

\footnotetext{
${ }^{192}$ Birol, Erdener; NationalEnergy Outlook of Turkey and Expectations from Nuclear Technology, World Nuclear Association, London, 2002, p.7
} 
the Natural Gas Market Law and the Petroleum Market Law, EPDK was also given responsibilities in the natural gas and oil sectors. ${ }^{193}$

The Turkish government has decided to reform the oil sector aiming at farreaching liberalisation based on a clearer legislative framework. This is implemented through the Petroleum Market Law (No. 5015) which was passed on 4 December 2003 and entered into force on 20 December 2004. The law governs "petroleum marketing activities", namely imports, refining, stocks and distribution/retailing of oil with all oil sector operations separated from each other. The largest enterprises in the Turkish oil sector are The Turkish Petroleum Corporation (TPAO), the Turkish Petroleum Refinery Corporation (TÜPRAŞ) and Petrol Ofisi (POAŞ) do not have any statutory monopoly but in fact have large market shares in their own fields.

The gas market operations are regulated by the Natural Gas Market Law (Law no 4646) of 2 May 2001. The law entered into force after an 18-month transition period on 2 November 2002. The objective of the law is to establish a competitive gas market, reduce state role in the sector and to harmonise the Turkish legislation with EU law. The main responsibility of EPDK in the gas sector is to set up and implement regulatory measures to ensure the establishment of a liberal and competitive natural gas market where all market segments will be open to new entrants. It also regulates and approves transmission, storage and wholesale tariffs, and until competition is achieved, all retail tariffs. $^{194}$

The Natural Gas Market Law limits the market share of any importer or wholesaler to $20 \%$ of the domestic market. This applies also to BOTAŞ, who cannot enter new purchase contracts until its share of imports falls to the required level. To reach this, a contract transfer programme has been launched by BOTAŞ, in accordance with the law, which requires BOTAŞ, to transfer at least $10 \%$ of its minimum total purchase quantity within the take-or-pay contracts every year to reach the $20 \%$ market share.

\footnotetext{
${ }^{193}$ Erdogdu, Erkan; Regulatory Reform in Turkish Energy Industry, EPDK, Ankara, 2006, p.2-3

${ }^{194}$ Turkey Energy Review , Energy Policies of IEA Countries, 2005, p.107-110
} 
The Electricity Market Law (Law 4628) of 20 February 2001 is the main law governing the electricity market. It made former laws on private investment in the electricity sector obsolete (Laws 3096, 3996 and 4283). The Electricity Market Law (EML) entered into force on 3 March 2001 but its implementation was subject to a twoyear transitional period. It aims at creating a competitive, transparent and commercially viable electricity market that encourages private investment without government guarantees and provides sufficient, reliable and low-cost electricity to consumers. It is for the most part compatible with the EU Electricity Directive of 2003.

The Electricity Market Law organized state owned assets under three different companies: Electricity Generation Company (EÜAŞ), Turkish Electricity Distribution Company (TEDAŞ) and Turkish Electricity Transmission Company (TEİAŞ). TEİAŞ besides being responsible for transmission, runs the balancing market and financial reconciliation. The EML also powered the formation of the Turkish Electricity Wholesale Company (TETAŞ). The main purpose of TETAŞ is to facilitate the financing of the costs of stranded contracts and it was seen as having a transitional role. $^{195}$

In contrast with all these liberalization movements in Turkey energy prices are still regulated by the government, with the exception of oil product prices which were liberalised in 1989. Since February 2001, all energy products have been subject to $18 \%$ Value Added Tax (VAT). Oil and gas are subject to Special Consumption Tax. Also various smal taxes and levies are exist on different types of energy.

Electricity prices are determined by EPDK. The price of electricity for households has almost doubled since 1990. In 2006, the prices were US\$10.2 cents/kWh for industry and US $\$ 11.3$ cents $/ \mathrm{kWh}$ for households. The average gas price is US\$ $0.41 / \mathrm{kWh}$ for industry and US\$ $0.48 / \mathrm{kWh}$ for households. ${ }^{196}$

The massive restructuring through legal and institutional arrangements in the electricity, oil and natural gas sectors encourage new and competitive investments. Further, privatizations in electricity and natural gas distribution as well as power

\footnotetext{
${ }^{195}$ Atiyas, Izaak; Elektrik Sektöründe Serbestleşme ve Düzenleyici Reform, TESEV, 2006, p.12

196 http://www.enercee.net/turkey.html, Austrian Energy Agency, 20.12.2009
} 
generation offers great potential for foreign companies due to lack of expertise and references on the part of Turkish companies. For instance, German EON Energie, Italian Enel and American AES are among companies which are closely following the tenders in electricity.

\subsubsection{Energy Policy and Main Energy Projects of Turkey}

The Turkish energy sector, with its current size of $\$ 30$ billion and projected size of $\$ 55$ billion by 2015 as well as the fundamental restructuring process it has been going through since 2001, attracts both local and foreign investors. The sector will need an investment amount of approximately $\$ 130$ billion by $2020 .^{197}$

\section{Table 4.1. Investment Needs of the Turkish Energy Sector}

\begin{tabular}{|lr|}
\hline \multicolumn{1}{|c|}{ Sector } & \multicolumn{1}{c|}{ Investment (\$ billion) } \\
\hline Coal Exploration \& Extraction & 5,109 \\
\hline Oil & 16,000 \\
\hline Natural Resources & 2,700 \\
\hline Water (DSI) & 6,093 \\
\hline Generation (EÜAŞ) & 458 \\
\hline New Generation Facilities & 91,276 \\
\hline Transmission & 938 \\
\hline Distribution & \multicolumn{2}{|c|}{} \\
\hline \multicolumn{2}{|c|}{ Total } \\
\hline
\end{tabular}

Source: Ministry of Energy and Natural Resources of Turkey

Turkey is in relatively close proximity to $71.8 \%$ of the world's proven gas and $72.7 \%$ of oil reserves, and also sits on several important waterways. Thus, Turkey is well-positioned to become a significant energy hub and transit state. For today Turkey's strategy is to become the fourth main natural gas artery of the EU.

Turkey's investments in oil production projects abroad are growing considerably. The Turkish Petroleum Corporation's (TPAO) investments abroad grew almost by a factor of ten in three years, from USD55 million (2001) to USD519 million (2004). TPAO's main ventures abroad are in Azerbaijan. For instance, TPAO holds a $6.75 \%$ share in the Azerbaijan International Operating Company (AIOC) and a 9\%

\footnotetext{
${ }^{197}$ Ozkan, Kürşat; Turkish Energy Market - Growth for Infrastructure and Financing, General Electric Turkey, 2006, p.32
} 
share in the Shah Deniz project. In addition to Azerbaijan, TPAO has also invested in Libya and Kazakhstan and is exploring ventures in Turkmenistan, Iraq, and Syria. ${ }^{198}$

Turkey has concentrated its efforts for the transportation of Caspian oil and gas reserves to Western markets on the realization of the East-West Energy Corridor, often referred to as the Silk Road of the 21st Century. The pipeline projects linking the Caucasus and Central Asia to Europe will be essential for the region's integration with the West. Secure and commercially profitable pipelines will help bring stability and prosperity to the region. Undoubtedly, for today the most strategic and essential projects of this region are Baku-Tbilisi-Ceyhan (BTC) oil and Nabucco natural gas pipelines.

Baku-Tbilisi-Ceyhan project. The central component of the East-West Energy Corridor is the BTC pipeline, which is a dedicated crude oil pipeline system that extends from the Azeri-Chirag-Deepwater Gunashli field through Azerbaijan and Georgia to a terminal at Ceyhan on the Mediterranean coast of Turkey, bypassing the environmentally sensitive Black Sea and the Turkish Straits. The pipeline can transport up to 1 million barrels per day (approximately $1.3 \%$ of the world's oil supply), and at 1760 kilometers is the second longest of its kind in the world. The first cargo of oil, which had traveled through the BTC pipeline to Ceyhan, has been loaded onto a tanker on 4 June $2006 .^{199}$

The Nabucco Project. A consortium of European energy companies including Turkey's Botas AS, Bulgarian Energy Holding EAD, MOL PLC of Hungary, Austria's OMV Gas \& Power GmbH, RWE AG of Germany and Transgaz SA of Romania has been planning for Nabucco's construction since 2002. The 3,300-kilometer (almost 2000 $\mathrm{km}$ is in Turkey) long Nabucco pipeline, with a planned maximum capacity of $31 \mathrm{bcm}$, is slated for construction in 2010 and is aimed at diversifying the EU's supply sources and improving competion for the benefit of the consumers. The project is estimated to cost 7.9 billion euro and planned to be operational between 2013-2015. Although

\footnotetext{
${ }^{198}$ Shaffer, 2006, p.100

${ }^{199}$ Turkey's Energy Strategy, European Commission, 2007, p.1-2
} 
Nabucco will meet 5 percent of Europe's gas needs, this will be important step in terms of diversification of source and competition for the market. ${ }^{200}$

The completion of the Nabucco natural gas pipeline project which will contribute to Europe's energy supply security is Turkey's important energy policy priority. The Nabucco Summit held in Budapest on the 27th of January 2009 gave an important opportunity for all parties to reiterate their political support to the Nabucco project and to assess the consequences of the Russia-Ukraine gas crisis.

Summing up all these prospects we can see that, Turkish energy sector offers one of the top growth opportunities for an array of business segments within the next decade. The growth drivers are diverse. ${ }^{201}$

- $\quad$ The continuing steady growth of GDP, rapid growth of consumption per capita and demographic structure in Turkey will drive a double digit demand growth at a multiple of GDP.

- The geographic disparity between the sources of primary energy and demand for oil and gas; is also driving growth for transportation of these commodities. Turkey's strategic location among multiple sources and consumers of primary energy will continue to drive the pipeline investments, while presenting opportunities for shipping industry vertical and its adjacencies such as ports.

- $\quad$ Continuing high input prices and dependency for imported gas have been creating a compelling case for increased renewable energy investments and entry into nuclear energy production.

- $\quad$ Continuing deregulation including privatization of electric distribution will bring new investments in distribution and control technologies.

All these represent an approximately $\$ 100$ billion business potential in the next decade for multiple industry verticals and needless to say this would not happen without

\footnotetext{
${ }^{200}$ The Nabucco Project and Turkey, Center for Strategic and International Studies, 2009, p.2-3

${ }^{201}$ Ozkan, 2006, p.32
} 
financing models. And only a healthy financial market backed with strong financial institutions and supportive legislation can efficiently arrange this potential.

\subsection{ENERGY DERIVATIVE MARKETS AND TURKEY}

Turkish investor's first introduction to derivatives markets realised after 1980s. But, when we look at the Turkish economy, it can clearly be seen that risk management and derivatives markets, as well as the institutionalized risk management culture established in the economy have failed to reach a satisfactory level and still are weak both in financial and real sectors, although this had constantly been on the agenda since about three decades. ${ }^{202}$ The question at this point is that why risk management principles could not be established in Turkish economy in a modern sense until now and why functionality in the derivatives markets could not be achieved in the proper sense.

\subsubsection{Evolution of Derivatives Markets in Turkey and TurkDEX}

Following the 1994 economic crisis in Turkey, foreign exchange forward markets powered by the Central Bank of Turkey, was essentially carrying the function of regain the control on forex markets. Besides the transactions realized in foreign derivatives markets and forward contracts which were not subjected for taxing, the first arrangement for futures and options markets in Turkey was made on 23.07.1995 with "General Principles of Organization and Regulation of Futures and Options Markets", published on Official Newspaper No.22352.

After this arrangement, the set of trading principles related to gold and foreign exchange futures and options contracts were defined in Istanbul Gold Exchange with the "Istanbul Gold Exchange Futures and Options Market Regulation" arrangement on 18.10.1996 published in Official Newspaper No.22791.

On 29.01.1997 with the issue of "Regulations Relating to Istanbul Stock Exchange Futures Market Membership and Operations" and "Regulations related to Istanbul Stock Exchange Futures Market Clearing House Membership and Operations",

\footnotetext{
${ }^{202}$ Serdengeçti, Süreyya; Derivatives Markets - Turkish Derivatives Exchange, Bank of International Settlement, 2006, p.2
} 
the basis for futures and options transactions became available to be processed on different stocks, interest-income securities, indices and other financial indicators. In Turkey, the first futures contracts were introduced by Istanbul Stock Exchange (ISE) in 2001. However, the first futures trading trial ended in a very short time because of the insufficient substructure. ${ }^{203}$

Afterwards, in 2003, the Turkish Derivatives Exchange (TurkDEX) was established and a formal trading in futures contracts started in February 2005. By the commencement of TurkDEX, futures trading officially started in Turkey. The TurkDEX is the only entity authorized by the Capital Markets Board (CMB) to launch a derivatives exchange in Turkey and according to the CMB regulations, membership to the TurkDEX is restricted to financial intermediaries. It currently has 89 members (mainly brokerage firms and banks) and all members are the direct clearing members ${ }^{204}$. Clearing is handled by the ISE Settlement and the Custody Bank Inc. (Takasbank). There is considerable interest in the potential success of this new market because of its role in price discovery and risk management prospects for the Turkish capital markets.

Graph 4.4. Transaction volumes of TurkDEX, 2005-2008 (number of contracts)

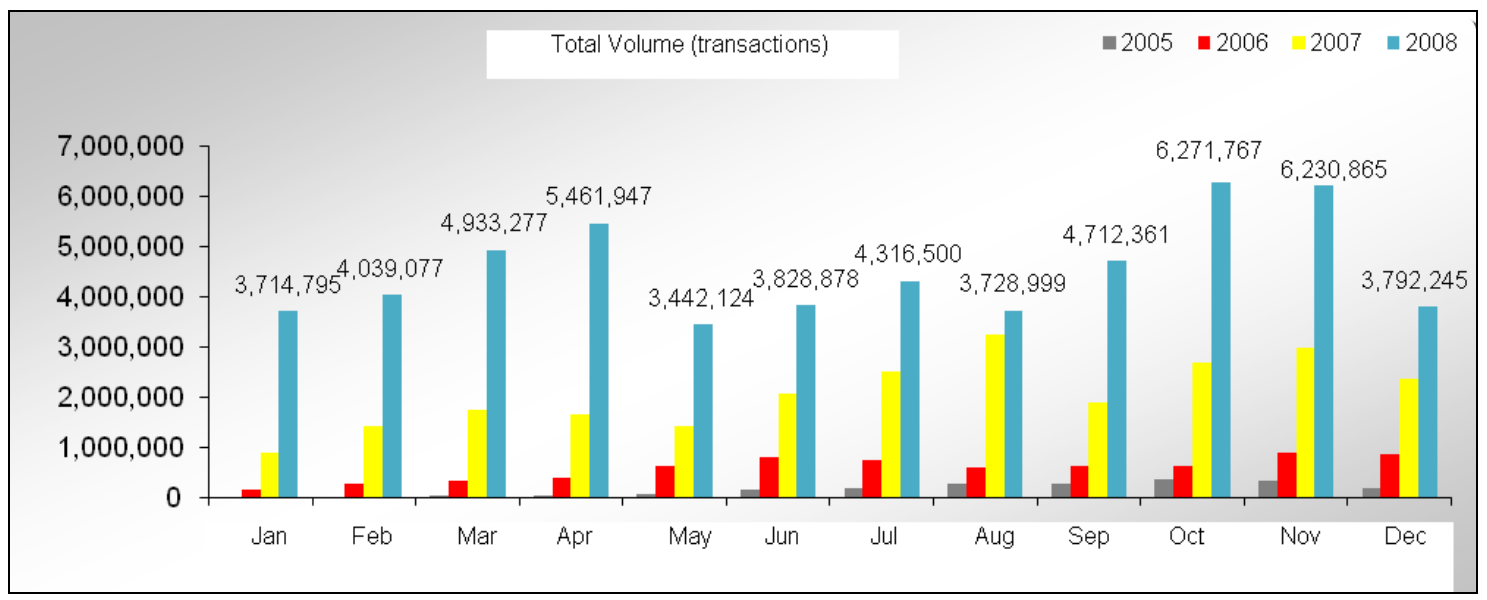

Source: http://www.vob.org.tr/VOBPortalTur/DesktopModules/QuotaHistoricMain.aspx

The TurkDEX has a fully electronic exchange system with remote access. There are two trading sessions, morning from 09:15 to 12:00 and afternoon from 13:00

\footnotetext{
${ }^{203}$ Vadeli Işlemler ve Opsiyon Borsaları, Istanbul Ticaret Odası, yayın no:19, 2006, p.11-12

${ }^{204}$ TurkDEX, http://www.vob.org.tr, 01.01.2010
} 
to 16:40. Recently only the futures contracts are traded in TurkDEX. Options, however, have not been listed yet. The contracts which are listed in TurkDEX include index futures (ISE-30 and ISE-100), currency futures (US Dollar/TRY and Euro/TRY), interest rate futures (for 91-day T-bill, 365-day T-bill and T-benchmark), commodity futures (cotton and wheat) and precious metal futures (gold). ${ }^{205}$ About $74 \%$ of the total value of the TurkDEX is on the Index futures. Trading in the futures market has grown remarkably in the past years. Total volume of transactions increased from 24.8 million in 2007 to 54.5 million in 2008. Total volume in TL indicates a 76\% increase from 118 billion TL to 208 billion TL.

\section{Graph 4.5. Transaction volumes of TurkDEX, 2005-2008 (TL)}

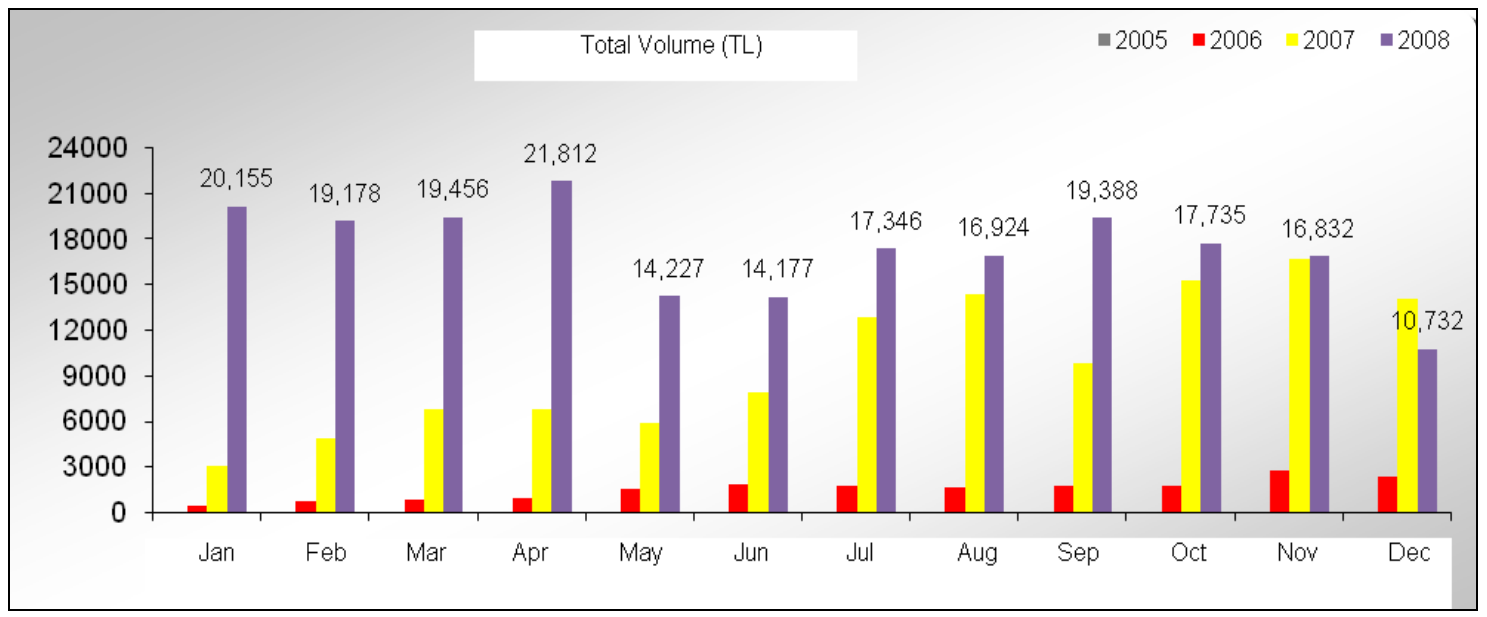

Source: http://www.vob.org.tr/VOBPortalTur/DesktopModules/QuotaHistoricMain.aspx

The commencement of TurkDEX took approximately 2 years and until the commencement, there were many conflicting thoughts claiming that it was very soon and risky to start a derivatives market in a developing country like Turkey. Nevertheless, it was a very remarkable attempt and it can be monitored that the derivatives markets in Turkey has been improving since its commencement. Consequently, it can be said that in a very short term, TurkDEX will be an indispensable part of the Turkish financial markets.

\footnotetext{
${ }^{205}$ Kasman, Adnan and Kasman Saadet; The Impact of Futures Trading on Volatility of the Underlying Asset in the Turkish Stock Markets, Physica A 387, 2008, p.2839
} 


\subsubsection{Applicability of Energy Derivatives in Turkey}

Today, such conditions as market structure, economic factors, social and psychological factors do not support a healthy functioning energy derivatives market in Turkey. Looking closely at the obstacles and problems confronting the use of energy derivatives in Turkey, it is clear that energy derivatives market are quite underdeveloped, alongside the fact that Turkish banks do not process energy derivatives products through any other foreign markets either.

In other words, it is obvious that the market participants or entities did not use energy related derivatives. Market barriers and problems in front of the development of a basic energy derivative in Turkey can be listed as follows:

- Information deficiency,

- The insufficient level of introduction and presentation of derivative transactions,

- The low level of importance given to risk management,

- The scarce knowledge and experience accumulation about derivatives, resulting in a deficit of investment-intermediary and brokerage institutions,

- The lack of organized derivatives markets,

- Economic instability,

- The problematic issues related to the accounting of derivative products.

One of the biggest obstacles for investors in processing derivatives products is information deficiency. Turkish investors, not receiving a systematic education related to both of derivatives and there usage sectors, are not using this products accepting them too risky. Due to the narrow field of use information propagation of such products is not at a desired level, so the actual market volume remains well below the expected volume. 
The sources that the information can be obtained with respect to derivative instruments are quite limited. As there is not an organized market infrastructure for local investors' entry, the units which can introduce derivatives are very limited, too. Although education related to such products is provided by universities and related companies, this knowledge is getting obtuse over time in the result of usage practice lack. The limited range of services provided by banks and the experience insufficiency of intermediary financial institutions related to derivative products are the other factors that contribute in weak knowledge accumulation for this sector.

In general, financial derivatives are used for risk management. The use of different financial instruments varies depending on the type of risk and its source point. In other words, the minimization or mitigation of all risks by a particular financial instrument is not a case. In this sense both individual and institutional investors, especially managing the risk of price fluctuations, are using either the classicconventional financial instruments or physical investments, due to scarce number of alternative derivative products.

The use of financial derivatives is not in its expected levels as of the overall economic structure in Turkey. High inflation and high interest rates along with unstable exchange rates forced the investors to gain more knowledge and experience concentrated in this sector. However, due to price risk, particularly in industry and manufacturing sectors, the broad acceptance of investing in physical stocks as an essential risk controlling tool weakens the development of financial instruments.

As of late 1994, with switching to the uniform accounting system, the standardization of applications was on target in Turkey. The recent system has only a fifteen-year application past which represents a very limited and immature period for the formation and accumulation of necessary knowledge and experience. Especially in this accounting reforms stage significant problems will be encountered in derivatives markets. Due to the spaces in legal infrastructure of accounting for derivatives, the problems are usually noticed only after their appearance and then the solutions are explored for. This case causes investors to evaluate derivative products in negative perspective. 
In the light of these problems, the suggestions for the development of energy derivatives' application in Turkey and avoidance of the possible problems that may arise from the use of energy derivatives are as follows:

- The preparation of legal regulation infrastructure is required for energy derivatives. The definitions and properties of these derivative instruments specified by law, will add a confidence to counterparties in using and solution of questions of such products.

- The legal basis for energy derivatives can be adapted for Turkish market based on the standard energy derivative contracts traded on such exchanges as NYMEX or ICE. However, here an important part is the adaptation of existing laws to international standards, other than the suitability of these contracts to underlying markets.

-The accounting arrangements relating derivative products should be processed in accordance with international accounting standards. The uniform accounting system is not an exact issue for this dilemma. The various researches are held about this issue, but particularly swap transactions which usually remain out of the balance sheet are used for tax escaping purposes.

-An efficient entry of TurkDEX to the energy markets should be supported. The development of both standardized and OTC derivatives markets and their active use by producers and consumers will also positively influence the energy derivatives markets. Because, it is not realistic to expect the development of the energy derivatives market in a country where the basic derivatives markets such as forwards, swaps, futures or options are underdeveloped.

- Economic stability should be maintained. This will attract a lump of foreign investments to Turkey consequently improving both the basic and energy derivatives markets.

- The number of institutional investors on the market should be increased. The major users of energy derivatives are energy producers, distributors and final 
consumers. The existence of active traders, buyers and sellers, in the market is an essential condition for development of liquidity in that market. Those who want to protect themselves with energy derivative contracts and who are willing to undertake the risk transfer, will provide the development of energy derivatives market in Turkey. The energy market will evolve over time, as public share will steadily be reduced opposed with the increasing volume of private sector in this market. From this scope, some legal restrictions preventing the institutions entry to the energy markets should be removed.

- For the development of the market, the related institutions, particularly personnel unit running the risk management in banks should be provided with periodic trainings. In Turkey, such training and education programs can be provided by TurkDEX. 


\subsection{COMPARISON OF SPOT AND FUTURE PETROLEUM PRICES}

\subsubsection{Data and Methodology}

This application was performed to examine the relationship between average import spot market petroleum prices in Turkey and NYMEX WTI oil future contract no. 4 prices. The data contains the weekly market closing prices between the years 20032009. The used data have been provided from the official websites of International Energy Agency and The Prime Ministry Undersecretariat of Treasury of Republic of Turkey. To achieve this, firstly the correlation test was performed on SPSS. Afterwards, the effect of spot market prices on futures market prices was analyzed through linear regression analysis.

\subsubsection{Correlation Analysis}

We need to explore the Scatter Plot on SPSS before beginning the correlation analysis. As we can see from the Graph 4.6 there is a positive and linear relation between the variables. And there is not any considerable outlier value in the historical data used. These mean that, we can execute the correlation analysis.

\section{Graph 4.6. Scatter Plot of Variables}

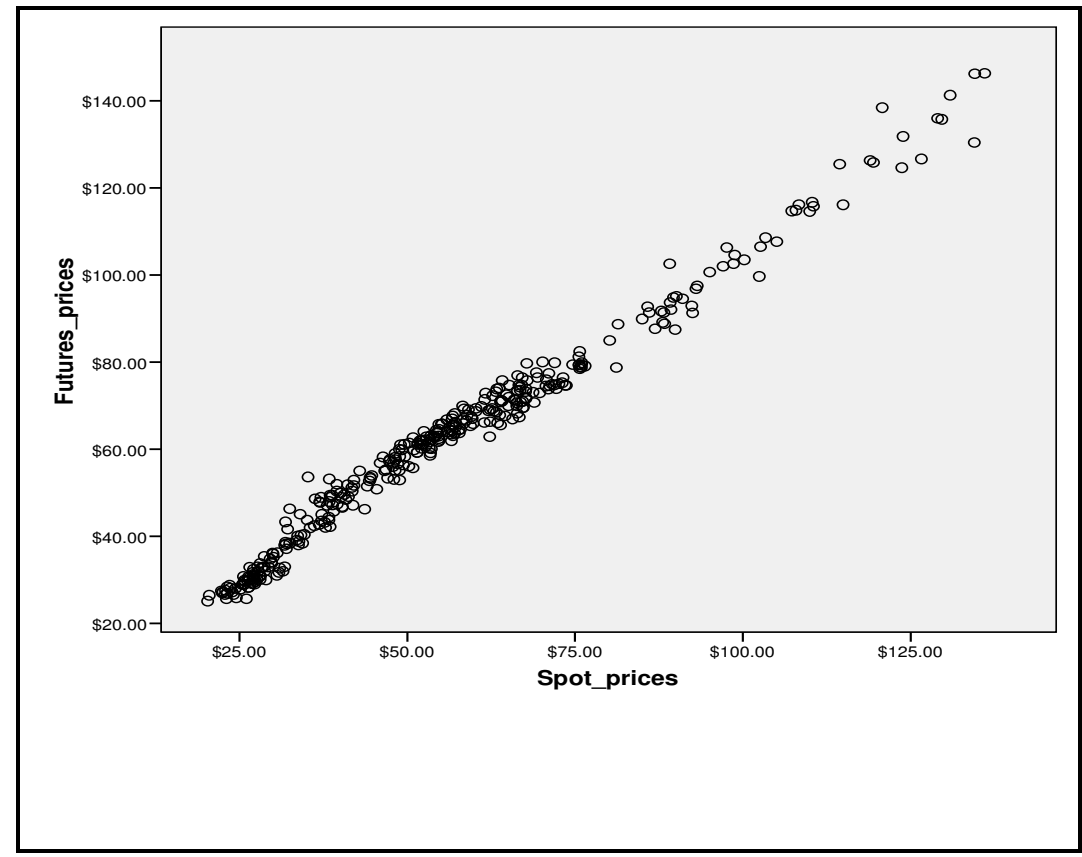


Further, exploring the Table 4.2 we can see that the spot prices variable has a positive significant correlation with futures prices variable with a strong 0.991 Pearson indicator at $1 \%$ significance level. The relationship is statistically significant.

Table 4.2. Correlations

\begin{tabular}{|l|l|r|r|}
\hline \multicolumn{2}{|c|}{} & Spot_prices & Futures_prices \\
\hline Spot_prices & Pearson Correlation & 1 & $.991(* *)$ \\
& Sig. (2-tailed) & & .000 \\
& $\mathrm{~N}$ & 365 & 365 \\
\hline Futures_prices & Pearson Correlation & $.991(* *)$ & 1 \\
& Sig. (2-tailed) & .000 & 365 \\
& $\mathrm{~N}$ & 365 & \\
& ** Correlation is significant at the 0.01 level (2-tailed).
\end{tabular}

\subsubsection{Regression Analysis}

While the correlation analysis determines the existence of relation between variables, the regression analysis defines the explanatory factor of dependent variable by independent variable(s). Here we will test whether spot petroleum prices as an independent variable have an effect on formulation of futures prices. As our data contains historical time series we check the Durbin-Watson value (Table 4.3), which exposes no autocorrelation between the variables. The explanatory power and significance level of this model will be examined with the following hypothesis:

$H_{0}: \quad$ An independent variable is not statistically significant to explain dependent variable.

$H_{1}$ : At least one independent variable is statistically significant to explain the dependent variable.

As the ANOVA table (4.4) suggests the $p$ value is below the significance level of 0.05 , we reject $H_{0}$, which means that the model is statistically significant. Looking at the Coefficients table (4.5) we can decide that both the constant and the independent variable with the $p$-values below the 0.05 significance level will be considered in the 
formulation of model. The explanatory power of this regression model is 0.982 , meaning that $98.2 \%$ of the variation of futures prices variable can statistically be explained by spot prices.

Finally, the correctness of the model is tested visually by the application of P-P Plot and Scatter Plot (Graphs 4.7 and 4.8) determining the normality of error terms distribution and the homoscedasticity of variances assumptions. Due to these graphs the regression model is statistically applicable.

Table 4.3. Model Summary (b)

\begin{tabular}{|l|c|r|r|r|r|}
\hline Model & R & R Square & $\begin{array}{c}\text { Adjusted R } \\
\text { Square }\end{array}$ & $\begin{array}{c}\text { Std. Error of } \\
\text { the Estimate }\end{array}$ & Durbin-Watson \\
\hline 1 & $.991(\mathrm{a})$ & .982 & .982 & $\$ 3.32828$ & 1.880 \\
\hline
\end{tabular}

a Predictors: (Constant), Spot_prices

b Dependent Variable: Futures_prices

Table 4.4. ANOVA (b)

\begin{tabular}{|c|c|c|c|c|c|c|}
\hline Model & & $\begin{array}{c}\text { Sum of } \\
\text { Squares }\end{array}$ & $\mathrm{df}$ & Mean Square & $\mathrm{F}$ & Sig. \\
\hline \multirow[t]{3}{*}{1} & Regression & 221924.412 & 1 & 221924.412 & 20033.844 & $.000(a)$ \\
\hline & Residual & 4021.124 & 363 & 11.077 & & \\
\hline & Total & 225945.536 & 364 & & & \\
\hline
\end{tabular}

a Predictors: (Constant), Spot_prices

b Dependent Variable: Futures_prices

Table 4.5. Coefficients (a)

\begin{tabular}{|ll|r|r|r|r|r|}
\hline \multirow{2}{*}{ Model } & & \multicolumn{2}{|c|}{$\begin{array}{c}\text { Unstandardized } \\
\text { Coefficients }\end{array}$} & \multicolumn{2}{c|}{$\begin{array}{c}\text { Standardized } \\
\text { Coefficients }\end{array}$} & \\
\cline { 3 - 7 } & & \multicolumn{1}{c|}{ B } & \multicolumn{1}{c|}{ Std. Error } & \multicolumn{1}{c|}{ Beta } & \multicolumn{1}{c|}{$\mathrm{t}$} & \multicolumn{1}{c|}{ Sig. } \\
\hline 1 & (Constant) & 6.749 & .429 & & 15.717 & .000 \\
& Spot_prices & .993 & .007 & .991 & 141.541 & .000 \\
\hline
\end{tabular}

a Dependent Variable: Futures_prices 
Graph 4.7. Normal P-P Plot

Normal P-P Plot of Regression Standardized Residual

Dependent Variable: Futures_prices

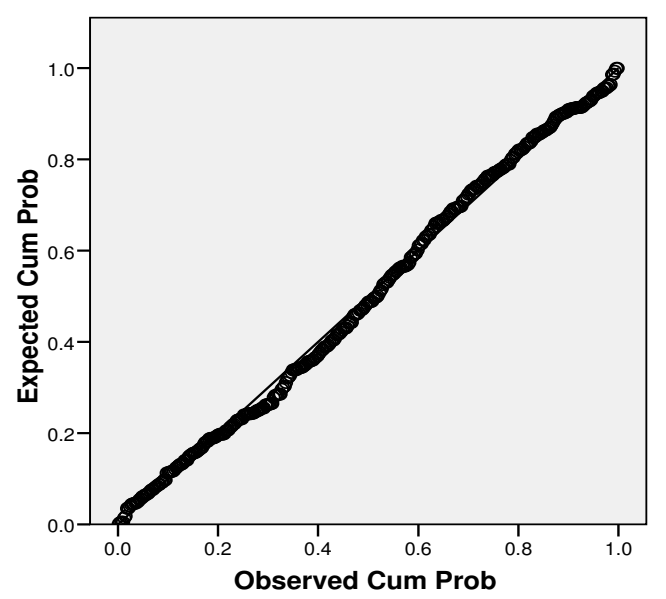

Graph 4.8. Scatter Plot of Regression Standardised Residual and Predicted Values

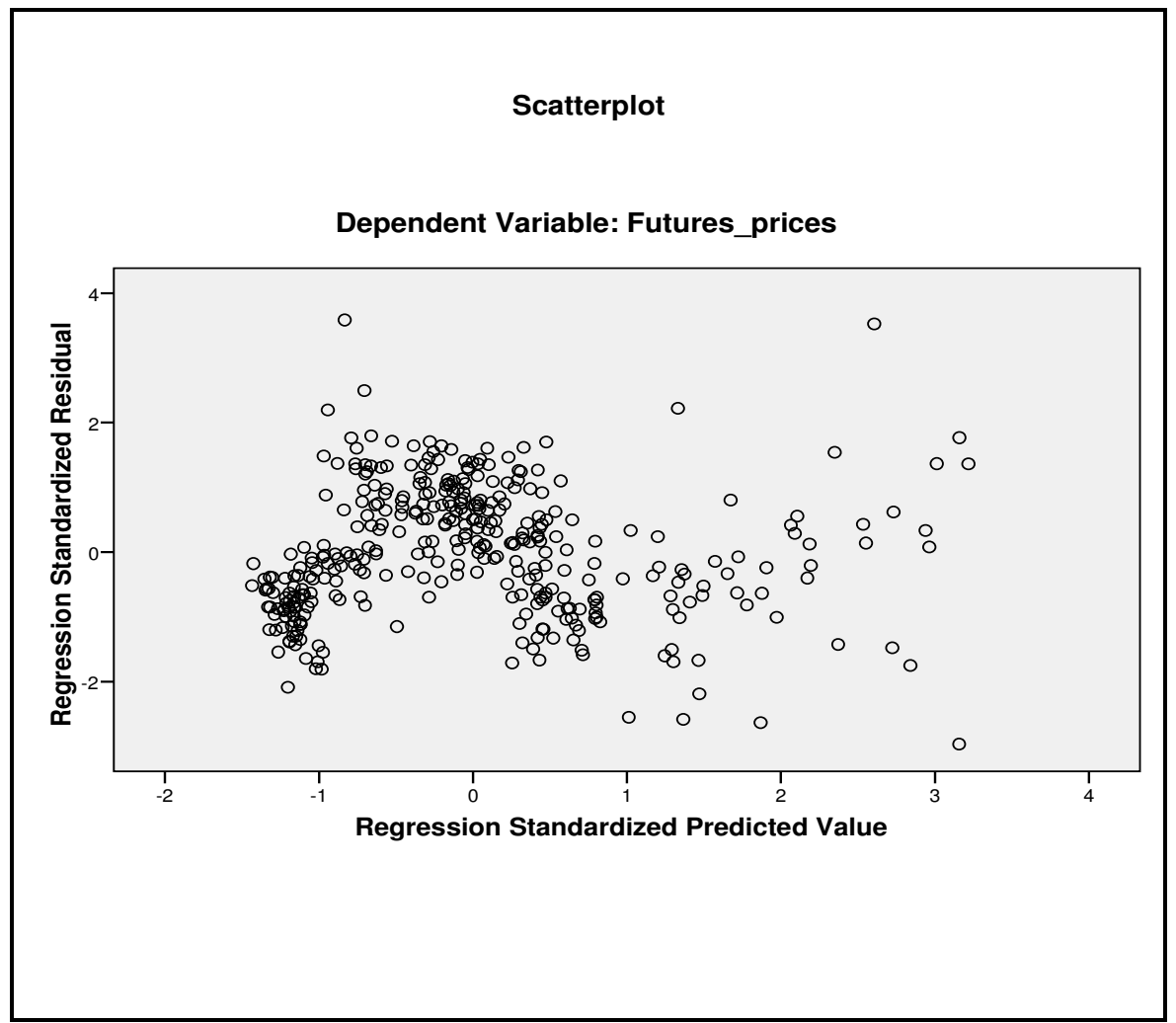




\section{CONCLUSION}

The liberalization in energy markets is now the main target in most countries. Deregulation of natural gas, initiated in the United States in the early 1990s, is slowly but inexorably moving into Europe and Asia. Simultaneously, deregulation of the power industry, launched in Scandinavian countries and continued in the United Kingdom and Australia, is taking root in North America. Introduction of the competitive natural gas markets has been an indisputable success from the point of view of liquidity, efficiency, and transparency. Power markets, on the other hand, are still too young to be judged with any degree of confidence. But, alongside with efficiency in the markets, liberalization and deregulation dramatically increased the degree of price uncertainty in the energy markets. This forced the current market participants to develop strong risk management tools for energy markets.

Energy risk management is no longer the gauche younger brother of the risk management family. Energy derivatives may be newer than foreign exchange derivatives, interest rate derivatives or other similar instruments, but over the last five years the market has attracted some of the keenest minds in risk management. They have been attracted in part by the novelty of the market, but also by the severity of the challenge. The success and growth of these contracts attracted a broader range of participants to the energy markets and stimulated trading in an even wider variety of energy derivatives. Today, many exchanges and over-the-counter markets worldwide offer futures, futures options, swap contracts, and exotic options on a broad range of energy products, including crude oil, fuel oil, gasoil, heating oil, unleaded gasoline and natural gas.

Weather derivatives represent an interesting departure for energy risk management, too. Weather derivatives are unlike previous instruments for several reasons: the underlying can't be traded, the hedge is against changes in volume, caused by changes in heating or cooling demand, rather than price, and the markets' outlook 
does not change from minute to minute with new information as it does in the markets for natural gas, oil, power or indeed interest rates.

Exchanges, energy traders, and electronic bulletin boards, investment banks and insurance companies compete vigorously for business in energy derivatives. Society relies on competition within and across these markets to ensure that risk is transferred at least cost. The exchanges and OTC traders have designed derivatives that respond to the concerns of market participants while recognizing the limits of location arbitrage, the importance of input-output price spreads to profits, and the role of price controls in retail energy markets. The world derivatives industry has made an enormous positive step forward in the last decade. Just in 10 years, global volume made an astonishing $646 \%$ growth at 15.5 billion contracts traded. Energy products transactions took a considerable part within commodities market with a volume of 580 million and showed a $16.8 \%$ increase in year 2008 .

Development of derivatives markets is proportional with development levels of countries and markets deregulation, liberalization and liquidity. Although, the great majority of energy reserves are based in Asia, the world's main advanced energy markets are located in North America and Europe including such giants like Chicago Mercantile Exchange Group, NYMEX, NordPool, European Energy Exchange, Tokyo Commodity Exchange, InterContinental Exchange and so on.

Today one of the growing participants in energy markets are energy hedge funds. In 2005 energy hedge funds held $\$ 50$ billion or $52 \%$ of overall capital of world hedge funds industry.

The liberalization is completely new phenomenon for Turkish energy markets. That's why they lack transparency, legal infrastructure and stability. The scarce of knowledge and experience of derivatives usage, low level of risk management activities, the information deficiency and the overall economic instability in the last two decades are some of the factors serving as the obstacles in development of energy derivative markets in Turkey. Today, TurkDEX is the main and only institution which has the necessary power to enter to energy markets in Turkey. 
The research application performed in the last section disclosed that spot petroleum market of Turkey is extremely correlated to the main petroleum futures benchmark of NYMEX and the main role playing factor here is the Turkey's position in oil market as a robust importer. This research also reveals that, despite the extreme price fluctuations, economic or political uncertainties and other energy market specific factors the oil futures prices can generally be estimated using the spot market prices. Theoretically Turkey is in the perfect position to perform actions in this market. But as we stated earlier the lack of the reserve hubs and the weak legal infrastructure in Turkey doesn't meet the requirements both for physical and for financial settlement of contracts.

Although Turkey may seem like a holder of serious problems in this market, the comparatively stable economy of last years raises the perspective of the increasing application of derivatives products over time. Becoming one of the main energy transit countries of the region in the next decade Turkey can transform to an important energy trading hub in the World. 


\section{REFERENCES}

Adelman, M. A. "World Oil Production and Prices 1947-2000". Quarterly Review of Economics and Finance. Vol.42, Issue 2, June 2002, p.169-191.

Alaton, Peter, Djehiche Boualem and David Stillberger. "On Modelling and Pricing Weather Derivatives", Applied Mathematical Finance. Vol. 9, Issue 1, 2002, p.1-20.

Atiyas, Izaak. Elektrik Sektöründe Serbestleşme ve Düzenleyici Reform, Istanbul: TESEV, 2006.

Barone-Adesi, Giovanni and Robert E. Whaley. "Efficient Analytic Approximation of American Options Values", The Journal of Finance. Vol.42, No:2, 1987, pp.301-320.

Bayraç, Naci H. Dünyada ve Türkiye'de Doğal Gaz Piyasasının Ekonomik Analizi, 1999, http://www.dtm.gov.tr/dtmadmin/upload/EAD/TanitimKoordinasyonDb/ dunyasayi15.doc, 20.12.2009.

Birol, Erdener. National Energy Outlook of Turkey and Expectations from Nuclear Technology, London: World Nuclear Association, 2002.

Blanco, Carlos. "Value at Risk For Energy: Is VaR Useful to Manage Energy Price Risk?”, Financial Engineering, December 1998.

BP Statistical Review of World Energy, June 2009.

http://www.bp.com/liveassets/bp_internet/globalbp/globalbp_uk_english/ reports_and_publications/statistical_energy_review_2008/STAGING/local_assets/2009 _downloads/statistical_review_of_world_energy_full_report_2009.pdf, 20.12.2009.

Burger, Marcus, B. Graeber, and Gero Schindlmayr, Managing Energy Risk, Chichester: John Wiley \& Sons, Ltd. 2007.

Burghardt, Galen. “9.899.780.283 Contracts Traded”, Futures Industry, March/April 2006.

Burghardt, Galen and Will Acworth. "2008 - A Wild Ride”, Futures Industry, March 2009.

Burgin, Daniel. "Implementing Pure FIX to one of Japan's Most Trading Bussisnes Commodities”, FIXGlobal, Vol. 1, Issue 4, 2004.

"Climate Change and the Power Industry", PricewaterhouseCoopers and Enerpresse, 2002.

Cuthbertson, Keith and Dirk Nitzsche, Futures and Forwards, PRMIA I.B.3., 2004. 
Dahl, A. Carol, International Energy Markets: Understanding Pricing, Policies and Profits, Oklahoma: PennWell Corporation, 2004.

Dunis, Christian L. and Vassilios Karalis. Weather Derivatives Pricing and Filling Analysis for Missing Temperature Data, Liverpool Business School, CIBEF, 2003.

Dvortsov, Victor. The Use of Weather Derivatives Energy Industry, 2004, http://cses.washington.edu/cig/outreach/seminarfiles/2006seminars/dvortsov010506.ppt, 20.12.2009.

Edwards, D.W., Energy Trading and Investing, McGraw-Hill, 2009.

Energy Complex. What do futures do for the energy markets?, Energy Media Group, 2006, http://www.gofutures.com/pdfs/NYMEX-energy-complex.pdf, 20.12.2009.

Energy Markets Outlook, 2007, http://www.berr.gov.uk/files/file41995.pdf, 20.12.2009.

Energy Review - Turkey, Energy Policies of IEA Countries, Paris: International Energy Agency, 2005

Erdogdu, Erkan. Regulatory Reform in Turkish Energy Industry, Ankara: EPDK, 2006.

Errera, Steven and Stewart L. Brown. Fundemantals of Trading Energy Futures and Options, Second Edition, Oklahoma: Pennwell, 2002.

Eydeland, Alexander and Krzysztof Wolyniec, Energy and Power Risk Management: New Devolopments in Modeling,Pricing and Hedginig, New Jersey: John Wiley \& Sons, Inc. 2003.

Fleming, J. and B. Ostdiek, The Impact of Energy Derivatives on The Crude Oil Market, Energy Economics, Vol.21, Issue 2, April1999.

Freedenthal, Carol. Natural Gas Purchasing, Energy Management Handbook, The Fairmont Press, Inc., 2007.

Fusaro, Peter and Vasey, Gary M. "Energy Hedge Funs: Why Have They Appeared Now?", Commodity Now, December 2004.

Fusaro, Peter C. Energy Convergence: The Beginning of The Multi-Commodity Market, New York: John Wiley \& Sons, Inc., 2002.

Fusaro, Peter C. The Energy Markets, PRMIA I.C.8, 2004.

Fusaro, Peter; The Next Wave Energy Trading, PRMIA, Vol.3, Issue 7, July 2004. 
Garman, Mark; Carlos Blanco and Robert Erickson. "Weather Derivatives, Insturments and Pricing Issues", Envorimental Finance, March 2000.

Gas Technology, Hedging Your Energy Cost Bets, 2003, http://www.energysolutionscenter.org/resources/PDFs/GT_S03_Hedging_Your_Energy _Cost.pdf, 20.12.2009.

Geman, Helyette. Risk Management In Commodity Markets, Chichester: John Wiley \& Sons Ltd., 2008.

Global Association of Risk Professionals, Foundations of Energy Risk Management, New Jersey: John Wiley \& Sons, Inc, 2009.

Gray, Simon and Joanna Place; Financial Derivatives, London: Centre for Central Banking Studies, Bank of England, March 1999.

Hale, Douglas R. Derivatves and Risk Managemet in the Petroleum, Natural Gas and Electricity Industries, Washington: Energy Information Administration, 2002.

Hamilton, James, Causes and Consequences of the Oil Shock 2007-2008, Brookings Papers on Economic Activity, 2009.

Haugh, Martin; Forwards, Swaps and Futures, Financial Engineering: DiscreteTime Asset Pricing, 2005, http://www.columbia.edu/ mh2078/FE04/for_swap_fut.pdf, 20.12.2009.

Henderson, Vicky. Black-Scholes Model, Nomura Centre for Quantitative Finance, Oxford University, 2004.

Hendricks, Darryl. Evaluation of Value at Risk Models Using Historical Data, Economic Policy Review, Federal Reserve Bank of New York, Vol. 2 Issue.1, 1996.

Hinz, Juri. Challenges in Pricing of Electricity Risk, 2004, http://www.ifor.math.ethz.ch/about_us/press/MitteilungenOct04.pdf, 20.12.2009.

Hull, John C. Options, Futures and Other Derivatives, Fifth Edition, New Jersey: Prentice Hall, 2003.

James, Tom. Energy Price Risk, New York: Palgrave Macmillan, 2003.

Kasman, Adnan and Saadet Kasman. The Impact of Futures Trading on Volatility of the Underlying Asset in the Turkish Stock Markets, Physica A 387, 2008.

Khindanova, Irina and Zauresh Atakhanova. "Stable Modeling in Energy Risk Management", Mathematical Methods of Operations Research, Vol. 55, Issue 2, 2002. 
Kubarych, Roger. "How Oil Socks Affect Markets", International Economy, Vol.19, Issue, 3, 2005.

Lewis, Nigel Da Costa, Energy Risk Modelling, Hampshire: PalgraveMacmillan, 2005.

Lhabitant, Francois-Serge. Handbook of Hedge Funds, Chichester: John Wiley \& Sons Ltd, 2007.

Lixin, Zeng. "Pricing weather Derivatives", Journal of Risk Finance, Vol:1, 2000.

Lucia, Julio J. and Eduardo S. Schwartz. Electricity Prices and Power Derivatives: Evidence From The Nordic Power Exchange, Anderson Graduate School of Management, No.1061, 2001.

McCann, Karen and Mary Nordström. Energy Derivatives: Crude Oil and Natural Gas, Federal Reserve Bank of Chicago, 1995.

McGowan, John J. "E-Enabled Energy Services: B2B in the Energy Sector", Energy User News, February, 2001.

Özkan, Kürşat. Turkish Energy Market - Growth for Infrastructure and

Financing, General Electric Turkey, 2006.

Pezier, Jacques. Market Risk Management, PRMIA III.A.1, 2004.

Pilipovich, Dragana. Valuing and Managing Energy Derivatives-Energy Risk, New York: McGraw-Hill, 2007.

Pure Energy; IntercontinentalExchange, 2005, https://www.theice.com/publicdocs/ice_capabilities.pdf, 20.12.2009.

Ronalds, Nick. "Asia on the Horizin: A Tour of Derivatives Markets Across the AsiaPasific Region”, Futures Industry, September-October, 2008.

Serdengeçti, Süreyya. Derivatives Markets - Turkish Derivatives Exchange, Bank of International Settlement, 2006.

Shaffer, Brenda. “Turkey's Energy Policies in a Tight Global Energy Market”, Insight Turkey, Vol.8, April-June, 2006.

Simons, Katerina. "Value at Risk-New Approaches to Risk Management", New England Economic Review, September 1996.

Smithson, Charles W. Managing Financial Risk, Third edition, New York: McGrawHill. 1998. 
Sipahi, Beril; Serra Yurtkoru and Murat Çinko, Sosyal Bilimlerde SPSS'le Veri Analizi, Istanbul, 2008

Stren, Harvey and Shoni S. Dawkins. Weather Derivatives As a Vehicle to Realise The Skill of Seasonal Forecasts, Bureau of Meteorology, Melbourne, Australia, 2003.

The Nabucco Project and Turkey, Center for Strategic and International Studies, 2009, http://csis.org/event/nabucco-project-and-turkey, 20.12.2009.

Turkey's Energy Strategy, European Commission, 2007, http://ec.europa.eu/enlargement/pdf/european_energy_policy/turkeys_energy_strategy_ en.pdf, 20.12.2009.

“Turkey's Fuel Market Sales Volume On The Rise”, Turkish Daily News (AA), 05.05.2008,

http://www.petform.org.tr/images/yayinlar/haftalik_e_bultenler/petform_oil_gas_bulleti n_36_09052008.pdf, 20.12.2009.

Unger, Gustaf. Hedging Strategy and Electricity Contract Engineering, 2002, http://e-collection.ethbib.ethz.ch/view/eth:26151, 20.12.2009.

Vadeli Işlemler ve Opsiyon Borsaları, Istanbul Ticaret Odası, yayın no.19, 2006.

Vasey, Gary M. Hedge Funds, Attracted By Energy Commodity Price Volatility, Set to Enter Energy Trading, UtilityPoint, 2004.

Weinstein, Jeremy. Energy Trading Contracting with Hedge Funds, The $58^{\text {th }}$ Annual Oil \& Gas Law Conference, 2007.

World Coal Research: A Comprehensive Overview of Coal, World Coal Institute (WCI), 2005, http://www.worldcoal.org/assets_cm/files/PDF/thecoalresource.pdf, 20.12.2009.

World Energy Council, Energy Report of Turkey - 2008, http://www.dektmk.org.tr/upresimler/2008_enerji_raporu.pdf, 20.12.2009.

World Energy Council - Turkish National Committee, Türkiye 10. Enerji Kongresi, Dünyada ve Türkiyede Enerji - Uygulamalar ve Sorunlar, Istanbul, 2006.

World Energy Outlook, Paris: International Energy Agency, 2008.

World Energy Outlook, Paris: International Energy Agency, 2009.

http://www.chicagoclimateexchange.com, Chicago Climate Exchange, 20.12.2009

http://www.cmegroup.com, Chicago Mercantile Exchange, 20.12.2009 
http://www.eex.com, European Energy Exchange, 20.12.2009

http://www.enercee.net/turkey.html, Austrian Energy Agency, 20.12.2009

http://www.enerji.gov.tr, Ministry of Energy and Natural Resources of Turkey, 20.12.2009

http://www.iea.org, International Energy Agency 2009

http://ww.nymex.com, New York Mercantile Exchange, 20.12.2009

http://www.sgx.com, Singapore Exchange, 20.12.2009

http://www.theice.com, Intercontinental Exchange, 20.12.2009

http://www.tocom.or.jp, Tokyo Commodity Exchange, 20.12.2009

http://www.turkstat.gov.tr, Turkish Statistical Institute, 20.12.2009

http://www.vob.org.tr, TurkDEX, 01.01.2010 


\section{BIOGRAPHY}

I was born in 1985 in Azerbaijan Republic. In 2002 I have accomplished my education in Baku secondary school no.279 and in 2006 graduated from the faculty of International Economic Relations of Azerbaijan State Economic University with honours diploma. In the same year I have applied to the interstate students program between Azerbaijan and Turkey, and won the TCS scholarship. In 2007 I began my masters education in Business Administration department of Social Sciences Institute of Marmara University. In 2008 I started my master thesis research focused on “Energy Derivative Markets” under Associate Professor Ceyda Rukiye Öztürk’s advisement.

Polad Azizov 